\title{
How young firms choose an early-stage open
}

\section{source ecosystem}

by

Parisa Haim Faridian, B.Eng.

A thesis submitted to the Faculty of Graduate and Postdoctoral Affairs in partial fulfillment of the requirements for the degree of

Master of Applied Science in Technology Innovation Management

Department of Systems and Computer Engineering

Carleton University

Ottawa, ON Canada, K1S 5B6

May 2011

(c) Copyright 2011, Parisa Haim Faridian 
Library and Archives

Canada

Published Heritage

Branch

395 Wellington Street

Ottawa ON K1A ON4

Canada
Bibliothèque et

Archives Canada

Direction du

Patrimoine de l'édition

395 , rue Wellington

Ottawa ON K1A ON4

Canada
Your file Votre référence

ISBN: 978-0-494-81679-0

Our file Notre référence

ISBN: 978-0-494-81679-0
NOTICE:

The author has granted a nonexclusive license allowing Library and Archives Canada to reproduce, publish, archive, preserve, conserve, communicate to the public by telecommunication or on the Internet, loan, distribute and sell theses worldwide, for commercial or noncommercial purposes, in microform, paper, electronic and/or any other formats.

The author retains copyright ownership and moral rights in this thesis. Neither the thesis nor substantial extracts from it may be printed or otherwise reproduced without the author's permission.
AVIS:

L'auteur a accordé une licence non exclusive permettant à la Bibliothèque et Archives Canada de reproduire, publier, archiver, sauvegarder, conserver, transmettre au public par télécommunication ou par l'Internet, prêter, distribuer et vendre des thèses partout dans le monde, à des fins commerciales ou autres, sur support microforme, papier, électronique et/ou autres formats.

L'auteur conserve la propriété du droit d'auteur et des droits moraux qui protège cette thèse. $\mathrm{Ni}$ la thèse ni des extraits substantiels de celle-ci ne doivent être imprimés ou autrement reproduits sans son autorisation.
In compliance with the Canadian Privacy Act some supporting forms may have been removed from this thesis.

While these forms may be included in the document page count, their removal does not represent any loss of content from the thesis.
Conformément à la loi canadienne sur la protection de la vie privée, quelques formulaires secondaires ont été enlevés de cette thèse.

Bien que ces formulaires aient inclus dans la pagination, il n'y aura aucun contenu manquant. 
The undersigned recommend to the Faculty of Graduate and Postdoctoral Affairs acceptance of the thesis

\title{
How young choose an early-stage open source ecosystem
}

\author{
submitted by
}

Parisa Haim Faridian, B.Eng.

in partial fulfillment of the requirements for

the degree of Master of Applied Science in Technology Innovation Management

Chair, Howard Schwartz, Department of Systems and Computer Engineering

Thesis Supervisor, Michael Weiss

Carleton University

May 2011 


\section{Abstract}

This research studies the decision making process that young practice to choose an early-stage open source (OS) ecosystem. The objective of this research is achieved through taking an ecosystem perspective on how companies select an OS project that is striving to become an ecosystem. Accordingly, the unit of analysis selected for this research is a network of customers and contributors to an OS project on the verge of evolving into an ecosystem referred to as an "early-stage OS ecosystem" throughout this paper. The theoretical framework of this research is developed using a framework in ecology that explains habitat selection. The research was designed to: first, choose and examine an OS project with indications of an early-stage OS ecosystem and identify its contributing users and firms; then, interview selected young on how they chose the specific project; and finally, analyze interview data. Findings of this research confirmed that the examined OS project has the potential to grow into an OS ecosystem by showing initiations towards transferring control from a single company to a foundation. The main contribution of this research is a checklist that assists young firms to evaluate and choose early-stage OS ecosystems. 


\section{Table of Contents}

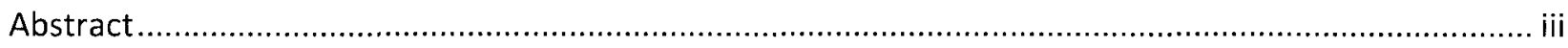

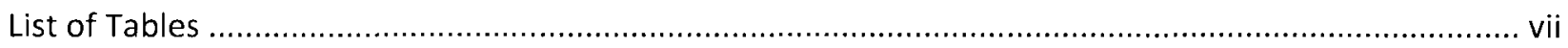

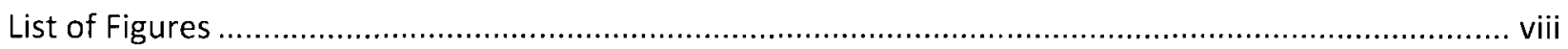

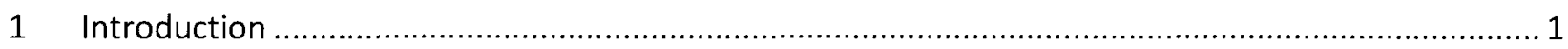

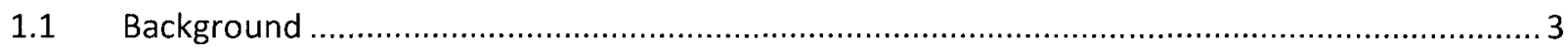

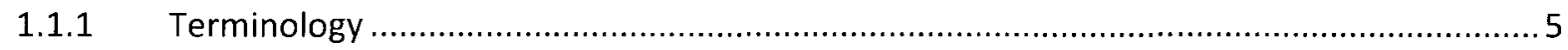

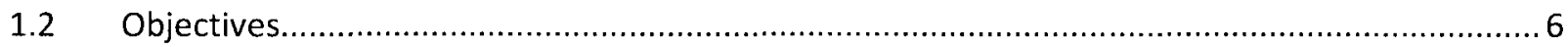

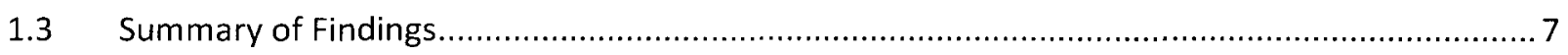

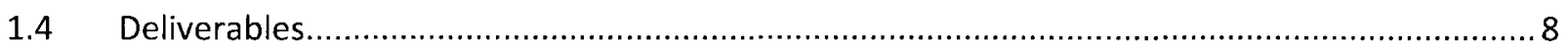

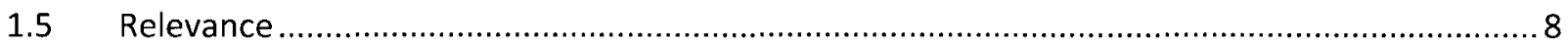

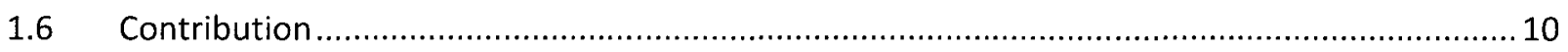

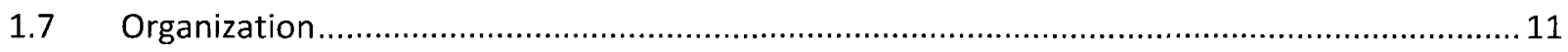

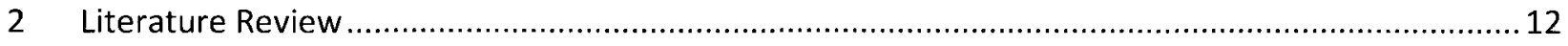

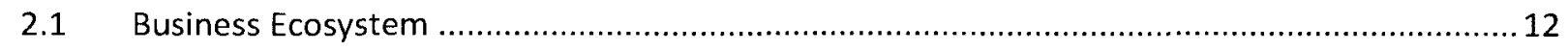

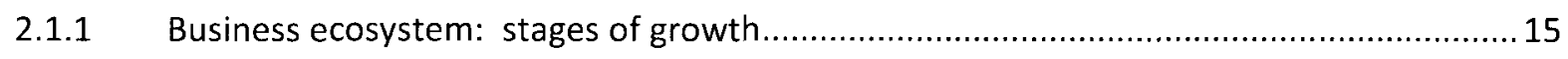

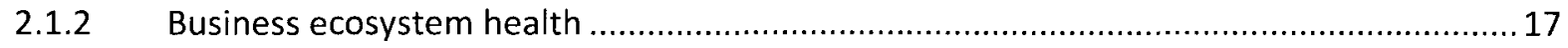

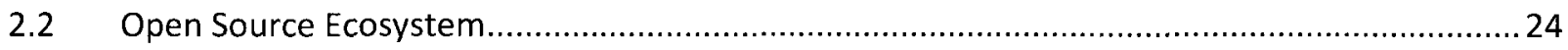

2.2.1 Open source ecosystem and academic spin-offs..................................................26

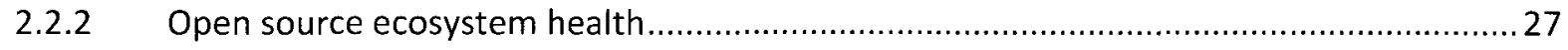

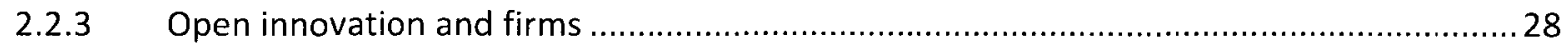

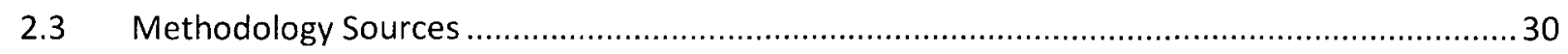

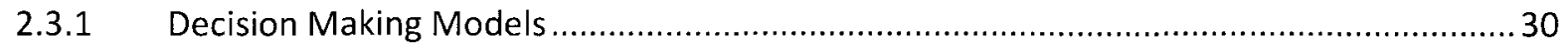

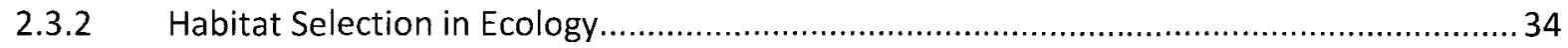

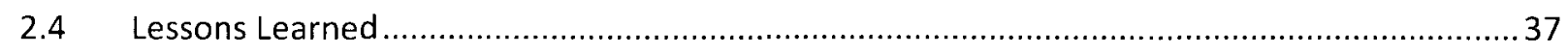

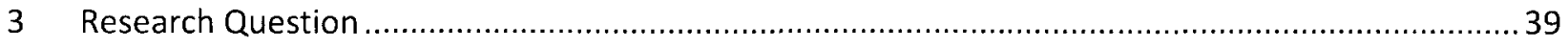

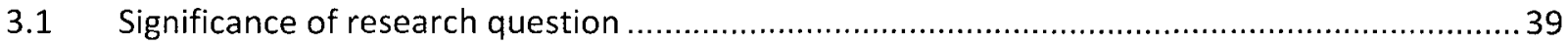

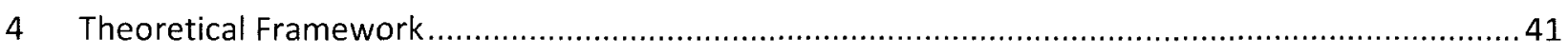

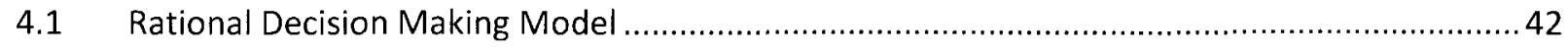

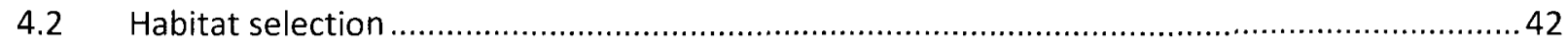

4.2.1 Techniques used in evaluating and choosing an OS ecosystem ...............................4 44 
4.2.2 Sources of information used in evaluating and choosing an OS ecosystem.....................46

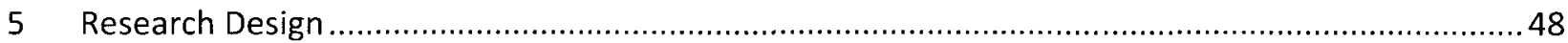

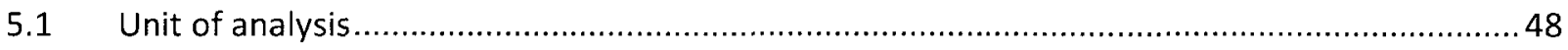

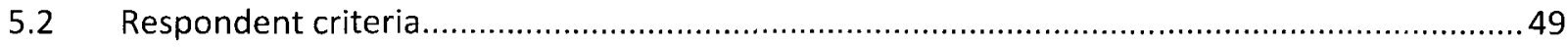

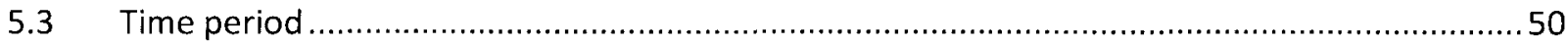

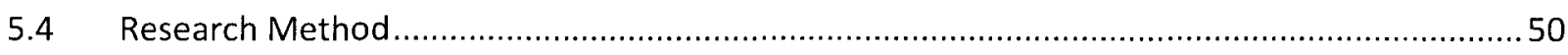

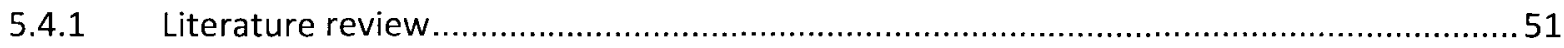

5.4.2 Selection and examination of OS community ............................................................. 51

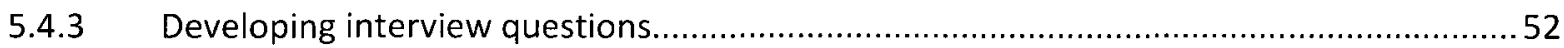

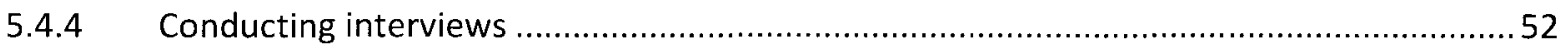

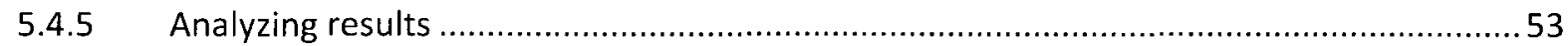

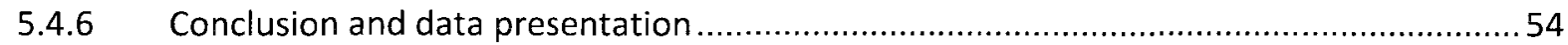

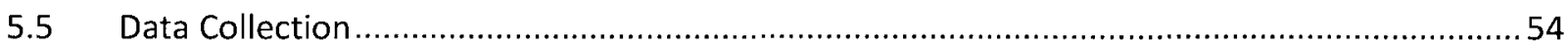

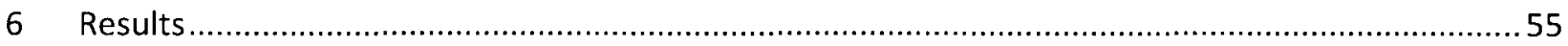

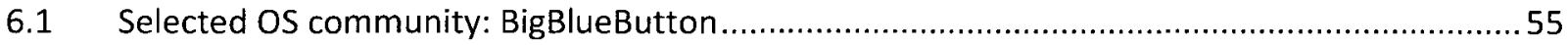

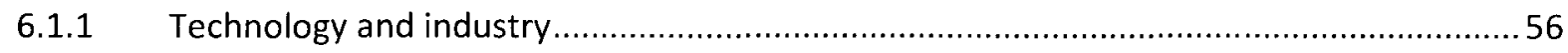

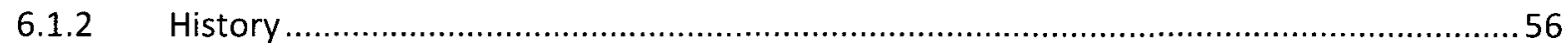

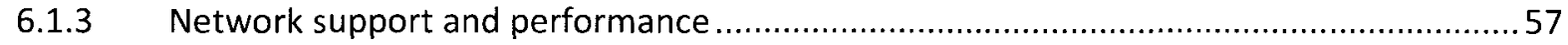

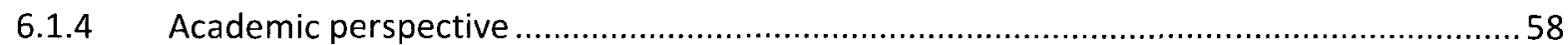

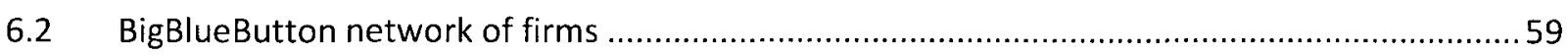

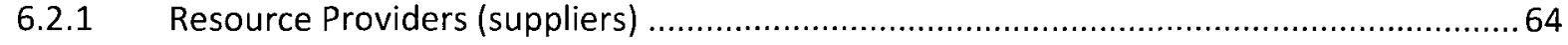

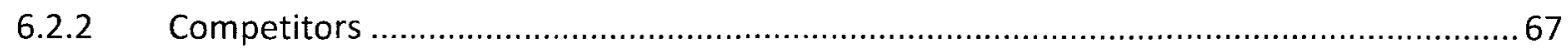

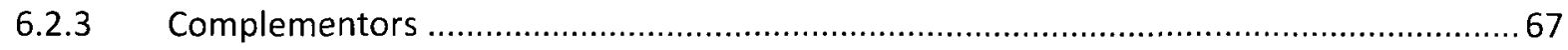

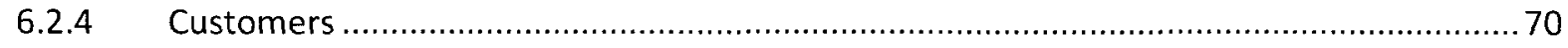

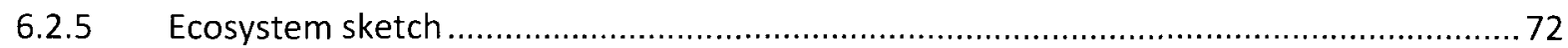

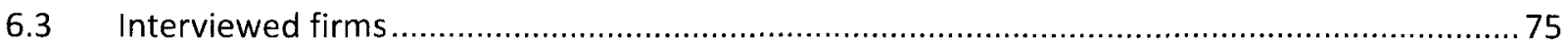

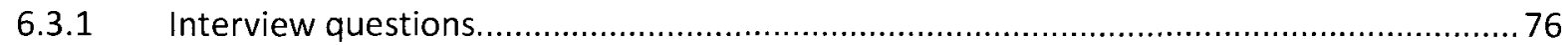

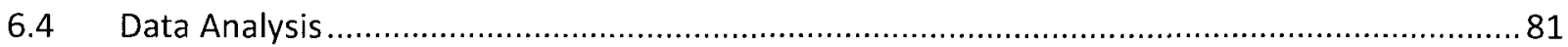

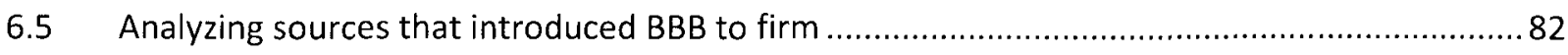

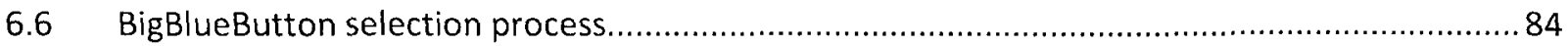

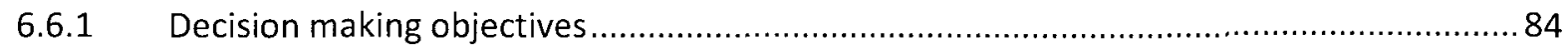

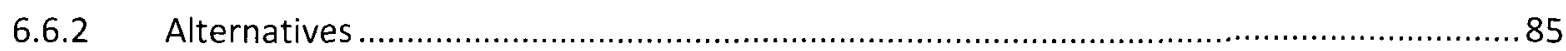




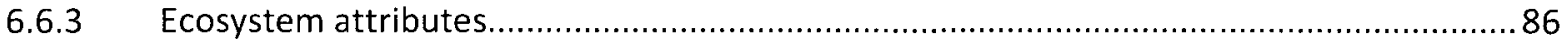

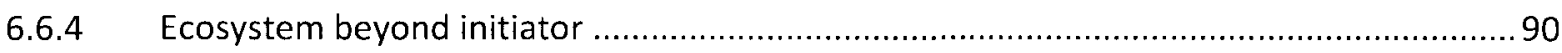

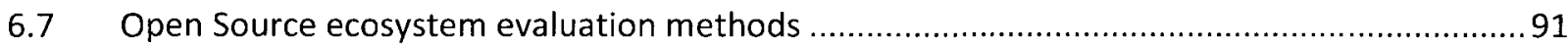

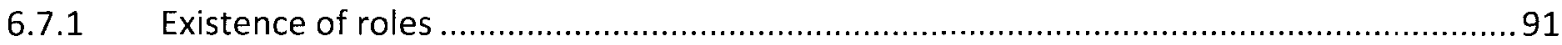

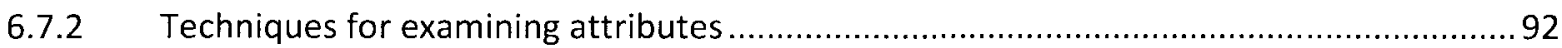

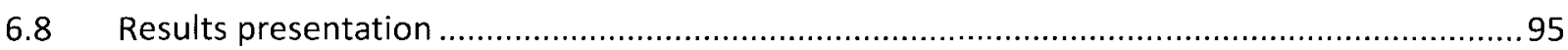

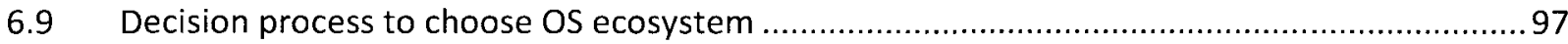

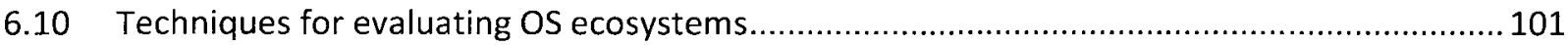

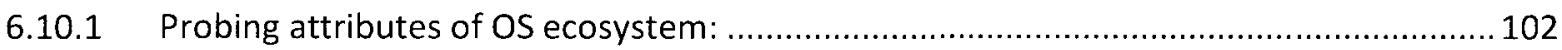

6.10.2 Using previous experiences with OS initiatives: ................................................... 102

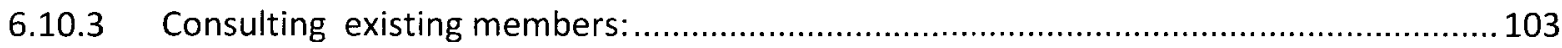

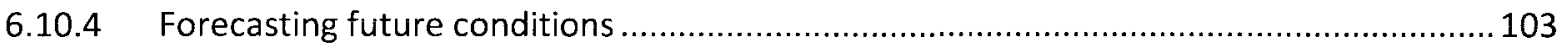

6.11 Sources of information to examine ecosystem attributes ..............................................104

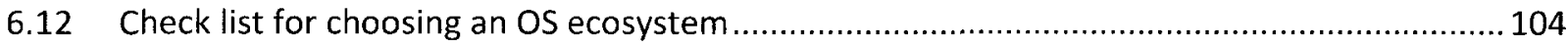

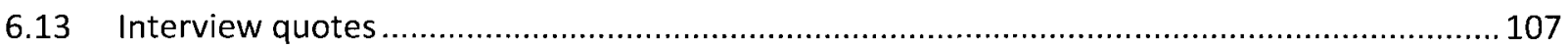

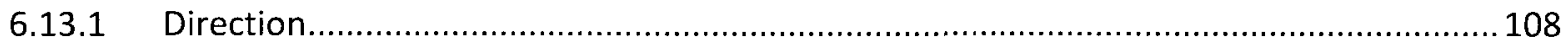

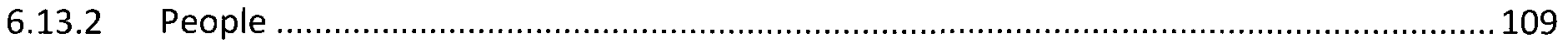

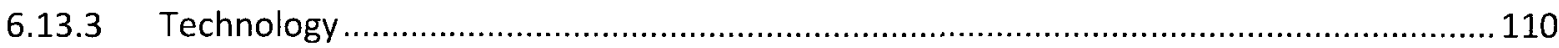

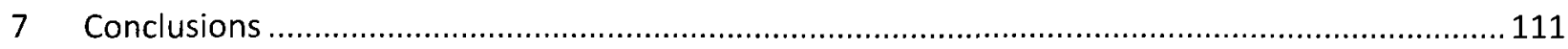

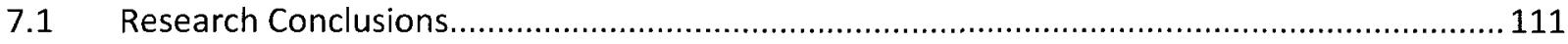

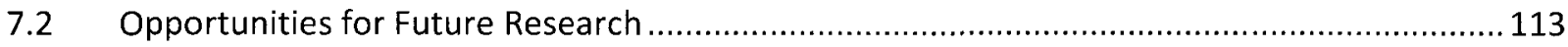

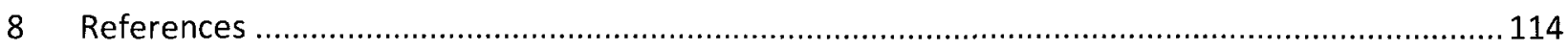




\section{List of Tables}

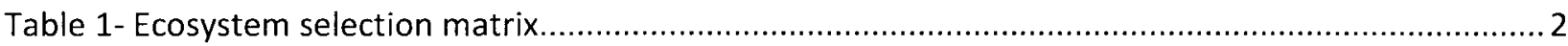

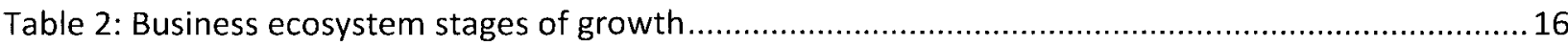

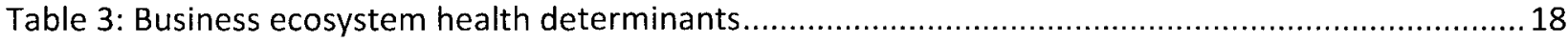

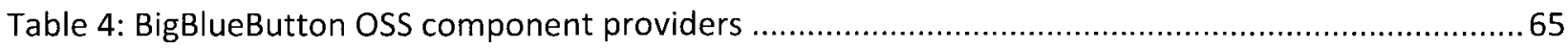

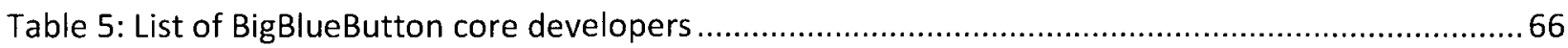

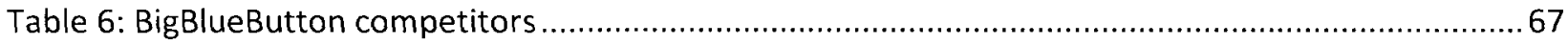

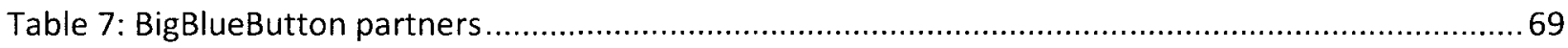

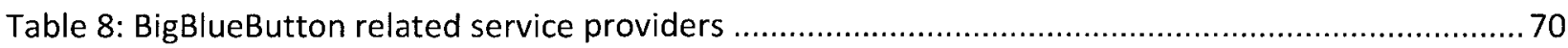

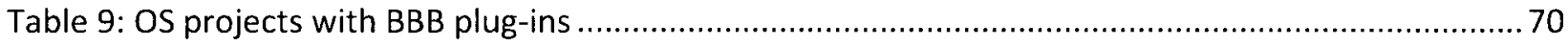

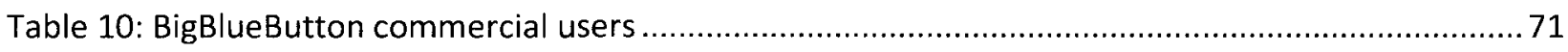

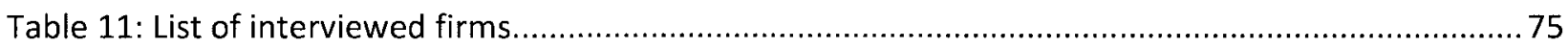

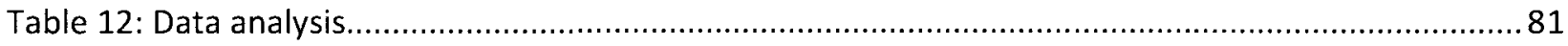

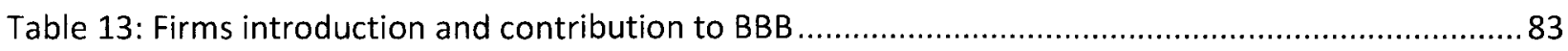

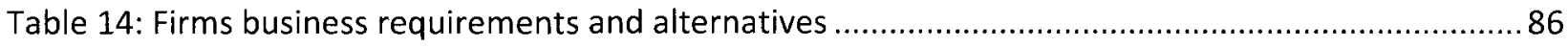

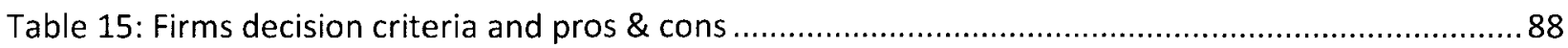

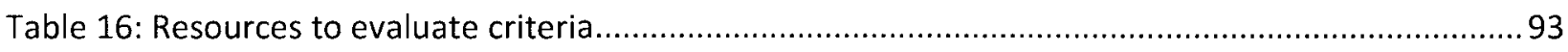

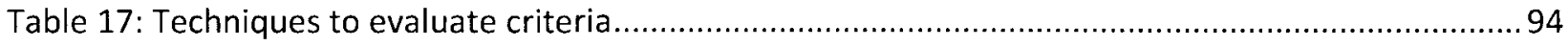

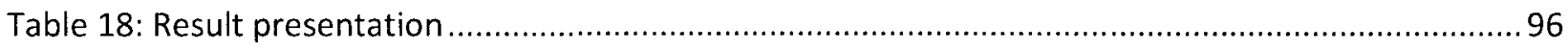

Table 19: Interview quotes providing insights on choosing OS ecosystems ................................ 107 


\section{List of Figures}

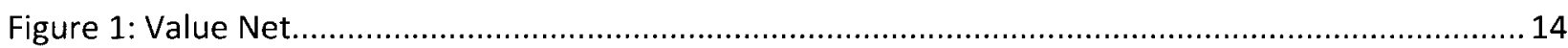

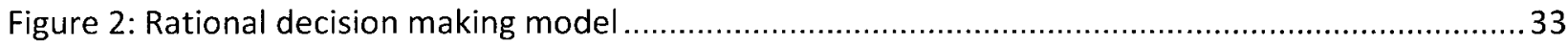

Figure 3: Ecosystem preference and Ecosystem quality........................................................ 35

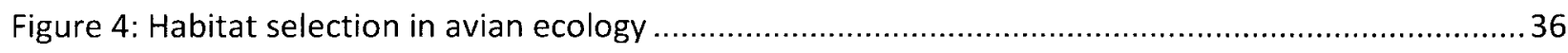

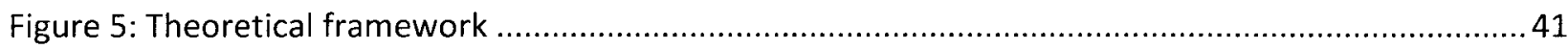

Figure 6- Framework of techniques used by firms to choose and evaluate OS ecosystems................. 45

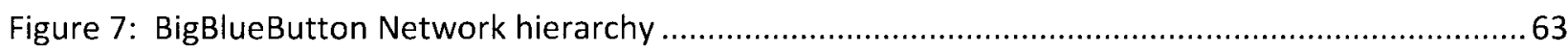

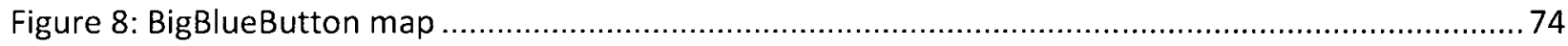

Figure 9: Use of rational decision making model in interview questions ................................... 77

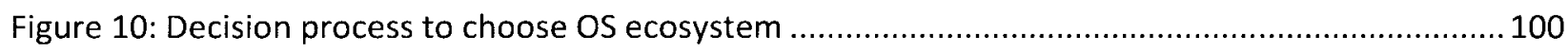

Figure 11: Techniques used in evaluating and choosing OS ecosystems ..................................... 101

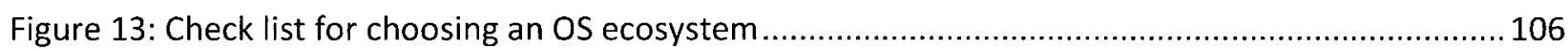




\section{Introduction}

The drivers and evaluation process that lead young firms to participate in an early-stage open source ecosystem are not clear: there are no clear indicators that firms can inspect. This ambiguity commonly manifests itself as lack of a holistic view that considers all attributes of open source ecosystems under one unified umbrella.

As young firms realize the value offered by OS initiatives, they are putting more emphasis on choosing OS projects that do not only provide immediate values but also promise a long-term business return. On the other hand, more young firms are exploring opportunities around sponsoring OS projects for the purpose of initiating OS ecosystems and adopting the role of keystone which subsequently put them on the map. Since the growth and marketing strategies that such firms adopt at early stages to acquire key members and form the foundation of ecosystem play a defining role in long term sustainability, their knowledge of how prospect members find OS initiatives and what attributes they consider in making their choice is imperative.

In order to clarify the focus of this research, it is important to identify the quadrant of ecosystem selection matrix that the research method and findings correspond to. The supporting data and insights collected from a young firms choosing young ecosystems (i.e. quadrant 1 ) were used in this research to provide contributions customized for young firms choosing young ecosystems (i.e. quadrant 1). 

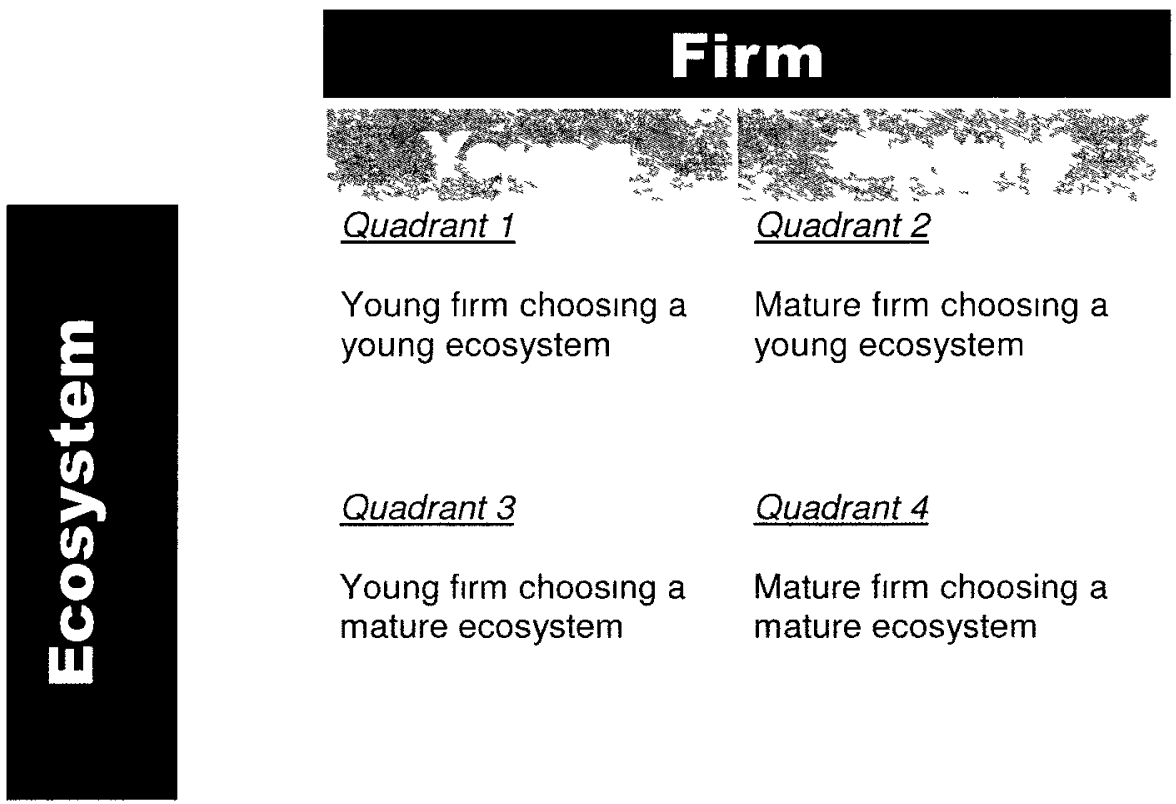

$\begin{array}{ll}\begin{array}{l}\text { Young firm choosing a } \\ \text { young ecosystem }\end{array} & \text { young ecosystem }\end{array}$

\section{Quadrant 3}

Young firm choosing a mature ecosystem

\section{Quadrant 4}

Mature firm choosing a mature ecosystem

The objective of this research can be achieved through taking an ecosystem perspective on how companies select an open source project that is striving to become an ecosystem. It is worth noting that while firms' existence in an ecosystem can be due to three main factors: random dispersal, differential mortality and habitat selection; the focus of this research is on the last factor which reflects furms' decision making process in choosing an ecosystem to participate.

In order to address this question, the researcher examined a network of for-profit organizations linked through an open source project thriving to birth into an open source ecosystem, which is referred to as an "early-stage OS ecosystem" throughout this paper. An open source ecosystem in the context of this research is defined as a form of collaboration between companies based on open source principles in order to share the cost and risk of developing products jointly and openly. 
Ultimately this research answers the question of "how do young chose an early-stage OS ecosystem?" by analyzing the decision making process that firms in this study practice to choose the open source project on the verge of flourishing into an OS ecosystem. Subsequently, a group of firms present in the ecosystem as a result of a decision making process and by choice as opposed to random dispersal were interviewed. While the interview data collected from these members covered topics from their objectives in engaging in the project, to how they were informed about the existence of such projects; the focal point was on the techniques and sources of information that these firms used in order to make their final choice.

Literature review on the subject revealed that the existing metaphors in ecosystem literature fell short in terms of analogizing firms as entities with conscious decision making ability in order to choose an ecosystem. Since most species have limited mobility and cannot choose their ecosystem, whereas birds can; the concept of habitat selection in avian ecology that explores how migrating birds explore and evaluate different habitats along their migration path and chose one to nest in, was discovered to be a close analogy to firms used in this study.

\subsection{Background}

As a key addition to modern business thinking (Moore, 2006); business ecosystems are considered too imperative to be ignored by firms. Literature predominantly emphasise on the significance of participating in business ecosystems in order to gain competitive advantage and insure firms' survival, and come short in addressing the initiation of engagement in ecosystems and the ecosystem evaluation process from firms' perspective. 
While the same statement applies to ecosystems anchored around open source initiatives, furthermore the identity of these ecosystems has been over shadowed by underlying OS communities; blurring the spotlight they merit as independent and separate entities. In other words, the notion of involvement in an open source ecosystem has been often confused with involvement in an open source community. While the latter is for the mere purpose of contributing or using the code developed in the open source community that creates the ecosystem platform, firms engage in open source ecosystems to build and improve their business models through benefiting from ecosystem value propositions while co-creating value collectively with other players.

The significance of above distinction is more evident at early stages of OS ecosystem growth, where the focus is on forming the ecosystem through defining value of proposed new product and services anchored around the OS project, as well as the best forms for delivering them. While short term success at this stage, is aimed at best defining and implementing value propositions, the long term success is dependent on cooperation among current partners to help fill out the full package of value for future ecosystem members. Attracting these important partners and actors and stopping them from joining other emerging ecosystems, is invaluable at this stage, since ecosystems that succeed and evolve in long term consciously attract and recruit a full community of strategically suitable partners, from the start.

Literature on health of ecosystems provides a broad definition based on metaphors from biology and tends to neglect the requirements specific to different types of ecosystem members. Considering that in business realm firms join ecosystems in pursuit of different objectives and according to their role in the ecosystem (i.e. partner, customer, related service provider, etc...), the notion of health in such a broad sense remains vague and futile to firms that need to evaluate 
and choose ecosystems in order to address their business requirements. Literature review segment of this research found the concept of "ecosystem fitness" as used in ecology and in the context of habitat selection a more proper replacement to the term health, since it reflects the ability of species in choosing an ecosystem that best fit their specific requirements.

The focus of this research is on the process of firms' engagement in open source ecosystems rather than open source communities that are embedded in such ecosystems. To understand ecosystems fully, we need to understand how ecosystems are formed through involvement of firms, how young firms determine ecosystem quality, and how ecosystem selection and firms' perception of ecosystem fitness with their requirement interact.

To summarize, it is not clear at what point of their business life cycle and due to what objectives or circumstances, young firms consider engaging in an OS ecosystem; what is the decision making process that firms follow to be part of an OS ecosystem and what emphasis they put on their decision; what criteria, risks, goals, and incentives do they consider in making that decision; also how they select the ecosystem and what makes them chose one ecosystem over the other.

\subsubsection{Terminology}

There are several terms that are essential to this research and therefore need to be defined and in some cases vividly differentiated from each other. These terms are commonly used and referenced in literature or are developed during this research to match the specific context. A business ecosystem is commonly described as international community consisting of economic players whose individual business activities define the fate of the community as a whole and vice 
verse (Moore, 2006).

An OS community is commonly described as a group of developers and users with a common interest in an OS project. OS community members interact with each other in order to share knowledge and resolve issues in regards with the project (Weiss \& Moroiu, 2008).

A sponsored OS community is one where one (or more) corporate entities control the community's short- or long-term activities (West \& O'Mahoney, 2008).

An OS foundation can be defined as a formal, legal, non-profit foundation to help manage OS community governance and assets (West \& O'Mahony, 2008).

An OS ecosystem as used in the context of this research is a network anchored around an OS foundation, of not only individuals (OS communities) but also commercial organizations that pursue different business models and requirements while contributing back to the foundation, other organizations and OS ecosystem as a whole.

An OS ecosystem initiator is the main corporate entity in charge of formation of OS foundation and transformation of a sponsored OS community into an OS ecosystem.

An early-stage OS ecosystem as used in the context of this research is the phase where OS foundation is being formed and initial key members are acquired and identified in order to implement and define ecosystem value propositions.

\subsection{Objectives}

This research is a preliminary study that examines how young firms choose an early-stage OS ecosystem. Subsequently, interview data from a selection of firms playing different roles in an 
early-stage open source ecosystem are collected as evidence that young firms utilize the techniques suggested in avian ecology literature in order to choose an OS ecosystem. The research will also examine the attributes of an OS ecosystem that firms consider in evaluating ecosystem fitness, along with their corresponding criteria, along with the techniques and sources of information used in evaluating these criteria. The results of the research will be supported by interview quotes.

\subsection{Summary of Findings}

The core findings of this research indicate that when choosing an open source initiative, firms rely on past experiences and the outcome of probing, as suggested by literature on habitat selection. However, they do not seek feedback from other members (except for the project initiator) on their experiences with the ecosystem. The research also confirmed the use a new information source that was not identified by the habitat selection literature; as findings showed that firms rely on forecasting the long-term success of the early-stage OS ecosystem. Therefore, in choosing an early-stage OS ecosystem where different attributes of ecosystem including technology and OS communities have not yet matured, firms rely on these techniques to help them predict the future of the ecosystem.

An additional finding which surfaced later in the research was firms' perception of the network of firms linked around the OS project and their awareness of its different attributes. While firms such as ecosystem initiator and partners who were majorly involved in different aspects of this network (e.g. OS project, ecosystem evolution, and its direction) went as far as calling the network an OS ecosystem, other firms with less involvement expressed no knowledge or interest 
in the network of firms around the project and its different aspects. For instance consumers limited their perspective of relation with the OS project to a simple sales activity. To summaries there was a great disagreement around the point at which the existing network of firms and individuals anchored around OS initiatives can qualify as an OS ecosystem.

\subsection{Deliverables}

This research achieves above objective through three main deliverables.

First, the research identifies the existing firms in a network anchored around an open source project, thriving to birth into an open source ecosystem, and their link to the current main project sponsor, as well as their contribution to the project and its evolution into an OS ecosystem.

Second, the different attributes of this network from the perspective of firms with different relation to the project and its main sponsor is identified.

Finally, the common techniques and available sources of information utilized by these firms in order to examine these attributes are identified.

\subsection{Relevance}

This research is relevant to two main groups.

The first group that can benefit from this research is researchers focused on the realm of open source ecosystems. This research introduces a new approach on examining how OS ecosystems 
come to existence, grow, and expand through observing how different player's involvement is initiated at very early stages. Through this approach, it also provides initial grounds for development of OS ecosystem fitness evaluation models that consider attributes of these networks beyond the OS communities that they are anchored around. This evaluation model would be specifically valuable since researchers have long struggled with different aspects of evaluating health and quality of an OS ecosystem:

"Quantifying the health of an open source ecosystem is a challenge... it is not clear which ones are most closely correlated with ecosystem health."

Mekki Macaulay, MekTek Solutions (2010)

Second group are young firms interested in exploring ecosystems as a new avenue of innovation and gaining competitive edge and consist of management of ecosystem members and keystones. The significance of this issue to this category has been recognized and cited repeatedly:

"IT executives must take a business-centric, holistic, and pragmatic approach to the open source ecosystem to take maximum advantage of relevant elements while avoiding the risks associated with unnecessary or irrelevant elements. “

Michael Dortch, Robert Frances Group (2007)

"Companies will consider connecting directly to open source ecosystems, engaging and building value collaboratively. "

Alex Fletcher, Entiva Group (2008) 
Young firms interested in engaging in OS ecosystems can use the contributions made by this research to examine their choice in terms of long term benefits and risks associated with engagement at early stages of OS ecosystem growth. Additionally, Keystones/sponsors of earlystage OS ecosystems can use the findings of this research on different aspects of the candidate members' perspectives, in order to strategize activities focused on expanding their ecosystem through attracting new members. Also, the findings on the types of evaluation criteria used by different role players can be used by keystones in building their brand, increase visibility and improve overall image of their ecosystem so that it would appeal to all categories of prospect members.

\subsection{Contribution}

This research contributes to the existing body of literature on the subject of OS ecosystems, and firm's engagement by introducing a new approach that shows how young firms' perspective of OS ecosystem and it is different aspects differ based on their specific business requirements and motives in engaging in early-stage OS ecosystems.

This research shows that: firms' engagement in OS ecosystems, decision making process and selection of ecosystem are adapted in order to cater to their unique business needs. It studies: young firms' objectives, goals, and selection criteria in joining ecosystem. Ultimately, the main

contribution of this research is a checklist that assists young firms to evaluate and choose earlystage OS ecosystems. 


\subsection{Organization}

The rest of this thesis is organized in eight chapters. Chapter one provides an introduction and background information to the research. Chapter two covers relevant literature review on the topics of: business ecosystems, OS ecosystem, and the resources used in establishing theoretical framework of the research: decision making models and habitat selections in ecology. Chapter three provides a statement of research questions and their significance in terms of novelty and value. Chapter four elaborates on the theoretical frameworks that are used in the research in order to answer the research questions. Chapter five explains the research approach used in order to collect the data required to a investigate research questions. Chapter six outlines the results of the research and discussion. Finally chapter seven provides a conclusion to the thesis, along with research limitations and contributions, and the opportunities for future research on the subject. Chapter eight will includes a list of references used in this research. 


\section{Literature Review}

Three categories of literature were reviewed for the purpose of this research; business ecosystems, OS ecosystems, and literature on ecology and habitat selection.

\subsection{Business Ecosystem}

Literatures offer diverse definitions of business ecosystem depending on the context of their research and subject industry. However in general terms business ecosystem is commonly described as international community consisting of economic players whose individual business activities define the fate of the community as a whole and vice versa (Moore, 2006). These economic players occupy interdependent niches embedded in the network of a business ecosystem in an effort to co-evolve their products. Since resources such as research and development, capital investments and operating process are shared among these members, in order for the ecosystem to succeed as a whole, members need to share a common vision.

The urgency of taking part or creating a business ecosystem rises from the fact that the leading competitive advantage in today's global market has shifted towards continuous innovation rather than efficiency and effectiveness in the past. The magnitude of business ecosystems was realized and leveraged by companies since late 60 's in different shapes and forms; from IBM modularization technology to Apple innovative visions.

Wynn (2008) bases its definition of business ecosystem on ecology and the respective conceptual elements with a difference of using operation of the units involved in an economic community instead of materials, energy, etc... It defines a business ecosystem as: 
“An arrangement of individual and organizational units involved in or influencing the circulation, transformation, and accumulation of capital (in various forms) through their functional activities."

The first step in creating an ecosystem is establishing concert and reliable grounds that act as initial incentive for players to join. This is usually a set of tools that provides building blocks for companies to create their products upon. These sets of tools are often referred to as "platforms" (Iansiti and Richards, 2006).

Companies that provide platforms around which other companies that wish to provide related applications and services to end users are flourished, play an essential role by nurturing innovation and productivity in ecosystem, and are referred to as "keystones" in literature. The companies that leverage the platform in order to create their own niche market are called "niche players".

Therefore keystone acts as the point of connection of members with members, and members with end users in ecosystem, and forms a "hub". The central position of a hub grants company with the power required to manage ecosystem resources and members capabilities in order to create and extract value in ecosystem and "Orchestrate the network" (Dhanarj \& Parkhe, 2006).

Brandenburger and Nalebuff (1995) focuses on value creation and capturing in what they refer to as "game of business". They introduce the "Value Net" as a schematic map to represent all the players in the game and the interdependencies among them and identify five elements of the game as PARTS which is short for: Players, Added values, Rules, Tactics, and Scope.

Players are customers, suppliers, substitutors, and complementors. Added value is what each of these players bring to the game and Rules impose structure to the game. Tactics represent 
players' perception of the game and how they play it accordingly. Finally, scope defines boundaries of the game.

The interactions in a value net occur in two dimensions where the company's customers and suppliers are placed along the vertical dimension, and company's substitutors and complementors are placed along horizontal dimension. While transactions such as flow of resources from the suppliers to company and flow of products and services from company to customers take place along vertical dimensions; on horizontal dimensions the company only interact with other players and no transactions take place.

The paper defines substitutors as alternative players that interact with company's suppliers and customers through purchasing products or selling resources. Complementors are defined as players that interact with company's suppliers and customers through purchasing complementary products or selling complementary resources.

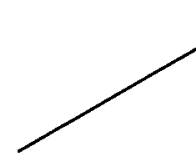

Substitutors

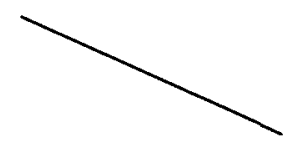

Customes

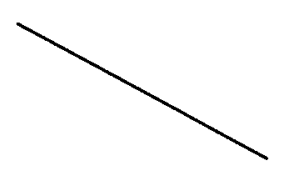

Company

Complementors

\section{Suppliers}

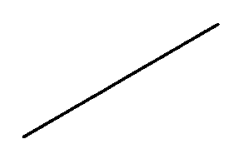

Figure 1: Value Net 


\subsubsection{Business ecosystem: stages of growth}

Much like biological ecosystems, business ecosystems can gradually start from collection of random elements to form a more structured community.

"Business ecosystems condense out of the original swirl of capital, customer interest, and talent generated by a new innovation"

Moore (1993)

Moore (1996) elaborates on the role of conscious choice by noting that although biological ecosystems do not always follow a random development pattern and animals do choose their habitats, mates and behavior based on their instincts; in the economic world, on the other hand, business entities always consciously strive in analyzing the situation and contemplating the possible outcomes of their decisions.

In general every business ecosystem develops in four stages: birth, expansion, leadership, and either self-renewal or death (Moore, 2006), stages of growth. 


\begin{tabular}{|c|c|c|}
\hline Stage & Goal & Required activities to reach goal \\
\hline Birth & $\begin{array}{l}\text { - Value creation } \\
\text { - Preventing competitors from } \\
\text { doing business within the } \\
\text { ecosystem }\end{array}$ & $\begin{array}{l}\text { - Acquiring critical lead customers, key } \\
\text { suppliers and important channels }\end{array}$ \\
\hline Expansion & - Reaching critical mass & $\begin{array}{l}\text { - Increasing scale and scope } \\
\text { - Standardization in key market segments }\end{array}$ \\
\hline Leadership & $\begin{array}{l}\text { - Maintain strong bargaining power } \\
\text { towards partners in ecosystem }\end{array}$ & $\begin{array}{l}\text { Encourage suppliers and customers to } \\
\text { work together to continuously improve } \\
\text { the complete offer }\end{array}$ \\
\hline $\begin{array}{l}\text { Self- } \\
\text { renewal }\end{array}$ & - Implementation of new ideas & $\begin{array}{l}\text { Delaying other ecosystems with similar } \\
\text { new ideas through consumers switching } \\
\text { costs or competitors' entry costs.... }\end{array}$ \\
\hline
\end{tabular}

During Stage 1, focus is on defining what customers want, and the value of a proposed new product or service and the best form for delivering it. While short term success at this stage, is in best defining and implementing customer value proposition, the long term success is dependent on cooperation with business partners to help fill out the full package of value for customers. Also attracting important partners and actors, stop them from joining other emerging ecosystems. 
Ecosystems that succeed and evolve in long term such as Apple's consciously attract and recruit a full community of strategically suitable partners from the start.

\author{
"Ecosystem cannot attract these key partners and actors unless it provides \\ compelling reasons and competitive advantages over other ecosystems for key \\ players to join. Understanding why different players prefer to join an ecosystem \\ over others enables keystones strategize accordingly."
}

It is important to note that different players in an ecosystem consider different criteria in joining and choosing a specific ecosystem based on their role, and business agenda. While some aspects of an ecosystem play an imperative role in one player's decision making process to join, it might not be as significant for other players.

In Stage 2, business ecosystems expand to conquer broad new territories and therefore ecosystems compete for market share while trying to exert pressure on new actors to join. However a business ecosystem will not expand unless at first and foremost it continues to add value to existing players while absorbing values from them in return in order to create an atmosphere where value is co-created and all players benefit and consequently attracts new actors as a result.

\title{
2.1.2 Business ecosystem health
}

The overall performance indicator of a business ecosystem is referred to as "health" in literature (Iansiti and Levien, 2002). There are three common determinants of business ecosystem health: robustness, productivity, and niche creation, and each determinant consist of factors. 
Table 3: Business ecosystem health determinants

\begin{tabular}{|l|l|}
\hline Ecosystem health determinant & Factors \\
\hline Robustness & - Survival rates \\
& - Persistence of structure \\
& - Predictability \\
& $\begin{array}{l}\text { - Limited obsolescence } \\
\text { - Continuity within the ecosystem }\end{array}$ \\
\hline Productivity & $\begin{array}{l}\text { - Total factor productivity } \\
\text { - Productivity improvements } \\
\text { Niche creation }\end{array}$ \\
\hline
\end{tabular}

\section{Robustness}

Also referred to as critical mass is the ecosystem ability to survive disruptions and consist of five factors: survival rates, persistence of structure, predictability, limited obsolescence, and continuity.

\section{1-Survival rates}

"Survival rates: Ecosystem participants enjoy high survival rates, either over time, or relative to 
other, comparable ecosystems." (Iansiti and Levien, 2002)

Hartigh et al. (2006) proposes that the survival rate of the business ecosystem members can be measured by counting the number of younger companies in ecosystem. And for or a longitudinal measurement they propose the number of bankrupt or start-up companies to be counted.

\section{2-Presistence of structure}

"Persistence of ecosystem structure: Changes in the relationships among ecosystem members are contained; overall the structure of the ecosystem is unaffected by external shocks. Most connections between firms or between technologies remain."(Iansiti and Levien, 2002) Hartigh et al.(2006) define persistence as the unchanged structure of the business ecosystem. They propose that changes of partners and the relationships between them can be measured by comparing data of multiple years of a business ecosystem.

Carley (1991) suggests that measuring number of relations and number of agents measured per year subject to structural changes can be used as an indicator of persistence of structure.

\section{3-Predictability}

"Predictability: Change in ecosystem structure is not only contained, it is predictably localized. The locus of change to ecosystem structure will differ for different shocks, but a predictable 'core' will generally remain unaffected." (Iansiti and Levien, 2002)

Hartigh et al. (2006) proposes that predictability of an ecosystem has a direct relationship with the changes in its connectivity to other ecosystems, meaning the more the changes in ecosystem connectivity to other ecosystems (through its member); the less predictable its behavior is over time. They suggest that the outbound links can be counted (companies that are member of more 
than one business ecosystem) over time and differences can be detected.

In their paper they refer to Dekker and Colbert (2004) which conclude that the most robust networks are highly connected and therefore more persistent.

Another factor that might be worth looking is the number of companies that play a role of the key node in a sense that eliminating them or any of their relationship in the ecosystem will result in major disruption or fragmentation and result the ecosystem to head towards unpredictable future. The work of Borgatti (2006) on identifying sets of key players in a social network can be a good reference in setting predictability measurements.

\section{4-Limited Obsolescence}

"Limited obsolescence: There is no dramatic abandonment of "obsolete" capacity in response to a perturbation. Most of the installed base or investment in technology or components finds continued use after dramatic changes in the ecosystems environment." (Iansiti and Levien, 2002) Hartigh et al. (2006) interpret limited obsolescence as the change in market share of a technology. Therefore limited obsolescence can be measured by changes of market shares for each technology, over multiple consecutive years.

\section{5-Continuity}

"Continuity of use experience and use cases: The experience of consumers of an ecosystem's products will gradually evolve in response to the introduction of new technologies rather than being radically transformed. Existing capabilities and tools will be leveraged to perform new operations enabled by new technologies." (Iansiti and Levien, 2002)

Hartigh et al. (2006) suggest the following three measurements to evaluate continuity: 
- Total amounts spent on technology-related education within a business ecosystem.

- Costs of change and upgrade to be able to keep up with new technologies over multiple consecutive years.

- Labor stability within the business ecosystem is a used measure for the continuity.

\section{Productivity}

Productivity defines continuous performance improvement and represents the ecosystem efficiency in converting inputs into outputs and consists of three factors as discussed in Iansiti \& Levien (2002): total factor productivity, productivity improvements, and delivery of innovations.

\section{1- Total factor productivity}

"Total factor productivity: Leveraging techniques used in traditional economic productivity analysis, ecosystems may be compared by the productivity of their participants in converting factors of production into useful work." (Iansiti and Levien, 2002)

Most Literatures are synonymous on using economic techniques to measure FTP. Hartigh et al. (2006) defines FTP as the efficiency of the relation between the amount of labor and capital employed and the additional value that is created.

Iansiti and Richards (2006) use labor productivity as a measure in analyzing the productivity of different domains of IT. They define labor productivity as output per hour of all persons (i.e. the ratio of the output of goods and services in dollars to the labor hours devoted to the production of that output). They argue that the growth in labor productivity is an important measure of the health of the IT ecosystem since it provides an indication of the real earnings growth accruing to the ecosystem. 


\section{2-Productivity improvement over time}

"Productivity improvement over time: Do the members of the ecosystem and those who use its products show increases in productivity measures over time? Are they able to produce the same products or complete the same tasks at progressively lower cost?" (Iansiti and Levien, 2002) In measuring productivity of an ecosystem it is not only important to have positive productivity but also its productivity improvements; considering the fact that an ecosystem is not healthy if it does not improve its productivity numbers over time. The same measures as stated for productivity can be used for measuring productivity improvement with the difference that they are measured longitudinally.

\section{3- Delivery of innovations}

"Delivery of innovations: Does the ecosystem effectively deliver new technologies, processes, or ideas to its members? Does it lower the costs of employing these novelties, as compared with adopting them directly, and propagate access to them widely throughout the ecosystem in ways that improve the classical productivity of ecosystem members?" (Iansiti and Levien, 2002) In order to measure the grade of delivery of innovations in an ecosystem, usually the effectiveness of the process of sharing innovation among the members and its consequent outcomes in terms of new innovations are studied. Sydow and Windeler (1998) suggest that the effectiveness of network can be measured based on the relationships companies have and the overall social embeddedness of the ecosystem meaning that the more relations and links among the player of the ecosystem translates to more opportunities to share information and therefore deliver innovations. They also suggest that effective use of resources can help in optimizing 
network effectiveness.

\section{Niche creation}

Niche creation represents ecosystem capacity to create and offer significant diversity and consequently original values to its members, and consists of two factors: variety and value creation.

\section{1- Variety}

"The number of new options, technological building blocks, categories, products, and/or businesses being created within the ecosystem in a given period of time." (Iansiti and Levien, 2002)

Hartigh et al. (2006) interprets variety of a business ecosystem as "the equality of the division of members over the species, i.e., the distribution between numbers of resellers, numbers of system integrators, etc. A different approach suggested by Hartigh et al. (2006) is specifying the distribution of targeted market segments within a business ecosystem.

\section{2-Value Creation}

“The overall value of new options created." (Iansiti and Levien, 2002)

The key in measuring this factor is identifying a quantifying measure of the value associated with the new technologies and options such as new compatibility or added features of a new release or any complementary products.

According to Hartigh et al. (2006) the value of such newly created options is articulated in the 
growth of the total turnover or profit of the business ecosystem. They suggest that in order to capture the specific overall value of new options, value created by newly introduced technologies or solutions be measured.

\subsection{Open Source Ecosystem}

Wynn (2008) modifies its definition of business ecosystem mentioned in previous stream in order to define an OS ecosystem as below:

"an arrangement of individual and organizational units, involved in or affecting the circulation, transformation, and accumulation of capital (in various forms) in order to provide cooperative development, testing, marketing, distribution, implementation, and support of open source software. “

A wide range of literatures place a strong emphasis on the network of open source communities as the heart of the open source ecosystems. These OS communities are described as group of developers and users with a common interest in an OS project where members interact with each other in order to share knowledge and resolve issues in regards with the project (Weiss \& Moroiu, 2008). West \& O'Mahoney (2008) explores the cases where these open source communities are sponsored by one or more corporate entities that control the community's short or long term activities, and refer to them as "Sponsored OS Communities". They also explain how formal, legal, and non-profit foundations can be created in order to help manage these communities' governance and assets. 
Literature such as Hauge and Ziemer (2009) study companies create an ecosystem of users and developers anchored around an OSS product by establishing interactions among diverse but related open source communities. These communities are based on different business models and therefore contribute different kind of benefits back to the ecosystem.

Agerfalk (2006) among other literatures noted the shift from OSS as community of individual developers to OSS as community of commercial organizations instead. These communities operate as symbiotic ecosystems where organizations which are commonly SMEs interact with each other in a spirit of co-opetition. They introduce OS ecosystem as:

"New forms of collaboration between organizations based on open source principles... in a spirit of co-opetition whereby companies, often SMEs, share cost and risk by developing software jointly and openly"

It is worth nothing that some literature such as Feller et al. (2008) do not use the term ecosystem but instead defines OS networks formed by small open source companies with complementary capabilities, in order to deliver a 'whole product'.

It is important to point out a recent literature that took an opposite approach to the subject of OS formation than the one used in this research. While the focus of this research is on how young firms find candidate OS ecosystems in order to fulfill their business requirement and make a decision to participate in their choice of ecosystem, Pendergast (2009) examined how potential participants in an OS ecosystem can be identified through a rigorous articulation of organizational motivation and ability. In other words, while Pendergast (2009) findings help managers and OS ecosystem initiators identify potential participants in order to initiate the 
ecosystem; the findings of this paper will help young firms identify potential OS ecosystems in order to achieve business objectives.

Pendergast (2009) identifies circumstance-based categories of the organizations present in its research sample as: Hotbed organizations (highest motivation and ability to participate in an OS ecosystem); Second wave organizations (sufficient motivation and ability to be considered after the initial target organizations); the dilemma organizations (difficult to be solicited in participation in the ecosystem); Disinterested companies (neither motivated nor able to participate). The units of analysis of this study are firms that belong to the first (hotbed organizations) and second (second wave organizations) category of organizations in Pendergast research.

\subsubsection{Open source ecosystem and academic spin-offs}

This research examines a new generation of OS ecosystems that is generated through development of academic spin-offs. Literature defines academic spin-offs as tools used by universities worldwide for the commercialization of the research carried out by their faculty and students (Rasmussen \& Borch 2010; Wright et al. 2007). Development of academic spin-offs are facilitated through interventions and initiative carried out by universities including entrepreneurship centers, contests for entrepreneur students, and technology transfer offices (Rasmussen et al. 2006).

Hudson and Tanev (2011) examine five collectives that support start up formations, in order to study the factors that affect academic spin-off efficiency. One of these collectives called Talent 
First is unique in a sense of supporting Ontario based startups by maintaining an ecosystem of companies that operate using a business model that is anchored around open source products and services. "Talent First" supports open source startups interested to join the collective through establishing and maintaining a unique link between university and business that offers academic contributions to open source, professional open source development skills, and skills needed to found and operate an open-source-based start up firms.

Therefore, it can be said that collectives such as Talent First initiate early-stage OS ecosystems by attracting, co-funding, and gathering young firms and start ups in a network anchored around OS foundations.

\subsubsection{Open source ecosystem health}

Wynn (2007) provides a framework for assessing the three dimensions of ecosystem health and explains them through case studies of open source ecosystems. Subsequently, it defines a healthy ecosystem as fallowing:

\footnotetext{
"An ecosystem that is capable of producing and circulating sufficient levels of capital to induce participants to contribute resources and effort can be considered to be a health one."
}

By analyzing the details of the Subject OS community, the paper discovers several aspects of health that are specific to open source projects that are sponsored by a single organization. It specifically looks as advantages and disadvantages of sponsorship including supporting resilience and singular focus on a single user's needs. Also, according to the paper, the 
mechanisms which empower dimensions of health in sponsored open source ecosystems are not the same for other types of open source projects such as community based open source projects.

Some literatures have taken notice on specific characteristics of OS ecosystem that raise from the non-monetary factors such as the role that relationships and dynamics among ecosystem members plays in overall health of ecosystem. For instance, considering that most of the Open Source developers (46\%) do not earn money from FOS developments (Alkhatib, 2008) it may not be easy to accurately measure factors such as labor cost. Alkatib suggests that direct rewards for individuals can be identified as the monetary revenues earned from related products and services such as commercial consulting, training, distribution, support and implementation services, and non-monetary rewards from current or future employers to seek higher wages or attractive job positions or career benefits. Regardless measuring these non-monetary benefits is definitely a challenge.

\subsubsection{Open innovation and firms}

The sense of urgency to create or be involved in business ecosystem has been recognized by many companies in IT industry- including the company behind the subject OS ecosystem of this research. In most cases which also apply to this research subject ecosystem, the company takes its first step in creating an ecosystem by signing off the rights of its product to an open source foundation. This is considered a major leap towards "open innovation" which allows intellectual property; ideas, skills and expertise flourish in absence of corporate boundaries (Chesbrough \& Garman, 2009). Furthermore in an "inside-out open innovation", the company moves some of its assets from inside company boundaries to outside and available to ecosystem members. 
Ghesbrough and Garman (2009) identify five inside-out open-innovation moves, from which the subject OS initiative exemplifies three as following:

1. Maximizing the leverage of company's IP for the company itself and others by letting outside partners benefit from company's products and continue its development

2. Growing firm ecosystem through building on ecosystems of potential innovation partners

3. Creating open domains to facilitate exchange of information and ideas with others, or reduce costs and expand participation by sharing available resources and services

Stuermer et al. (2009) explores the benefits and incentives for individuals and firms to privately invest resources to create public goods innovations, by using imperative evidence of a real case of private-collective innovation. It also defines hidden costs associated with such investments which include: difficulty to differentiate, guarding business secrets, reducing community entry barriers, giving up control, and organizational inertia. This type of innovation is called private investment model of innovation and is similar to open innovation with a difference that the later does not assume that IP rights are set in a way that the resulting innovation is accessible by public for free. Open source software development is a common example of private-collective innovation model where the licensing is non-exclusive, making the software available to public for free.

Firms' involvement in networks built around open source initiatives such as open source communities are studied and noted in different papers. Dahlander and Magnusson (2008) investigate how firms use open source communities and what role their business models play in their use of such communities. According to this paper, firms use OS communities to expand the resources available to them in innovation processes. However, since innovation is usually 
distributed there is a need for organized coordination and control the development and use of the resources in OS communities.

\subsection{Methodology Sources}

Two streams of literature were reviewed in order to create the foundation for research methodology: decision making models and avian ecology.

\subsubsection{Decision Making Models}

In order to study how young firms make the decision to join ecosystems, we use a common rational decision making model framework. This model has been referred to in literature under different titles based on the context, such as "the Classical Rational Problem Solving Process" and "the Rational Comprehensive Method" (Harper \& Stein, 1995). However it represents a single approach to problem solving which requires systematic evaluation of alternatives in order to reach a pre-defined goal.

Therefore decision making process in an essence is consistent of information, data, and facts and believes of decision makers. It is important to note that while data plays a major role in decision making process, it won't be useful unless it is analyzed and processed by decision makers.

Robbins and Judge (2007) introduces the rational decision making model that consist of six basic steps. These steps could vary according to the context and nature of decision making process; however it can be generalized as following: 


\section{Step 1: Define objective}

This step consists of verifying, defining \& detailing the problem. This step requires gathering some preliminary information to help recognize the real problem, define goals and start primary analysis.

This step is commonly underestimated by top level managements; however weak problem identification can result in an inaccurate decision making and have negative effect on overall process.

\section{Step 2: Identify decision criteria}

This step involves generating evaluating criteria as measurements to determine success and failure of alternatives to the problem. Part of this step could consist of allocating weights to different criteria which helps in comparing available alternatives and choosing the one most suitable.

\section{Step 3: Identifying alternatives}

In this step final solutions to the problem are identified. Having access to information that helps explore all possible alternatives is essential part of this step. The optimal solution will be only reached if it exists in the set of alternatives found in this step.

\section{Step 4: Evaluate alternatives}

The alternatives found in previous step need to be evaluated in terms of feasibility, risks, and implications. 
Risk: Despite the usual degree of uncertainty in decision making process which can lead to potential risks, the risk analysis can help determine if the risk associated which each alternative is manageable.

Impact: Considering the potential expected and un-expected consequences of each alternative can help chose the one with best outcome.

Cost-Benefit: It is important to choose a solution that will work in long term in terms of financial feasibility.

Step 5: Choose the preferred alternative

After evaluating different alternatives the next step is analyzing the results and comparing alternatives.

Step 6: Re-evaluate the choice

This step takes place over a long period of time and consists of monitoring of the outcomes of the alternative that was chosen in previous step. Based on the feedback received the decision making can be revised over time. 


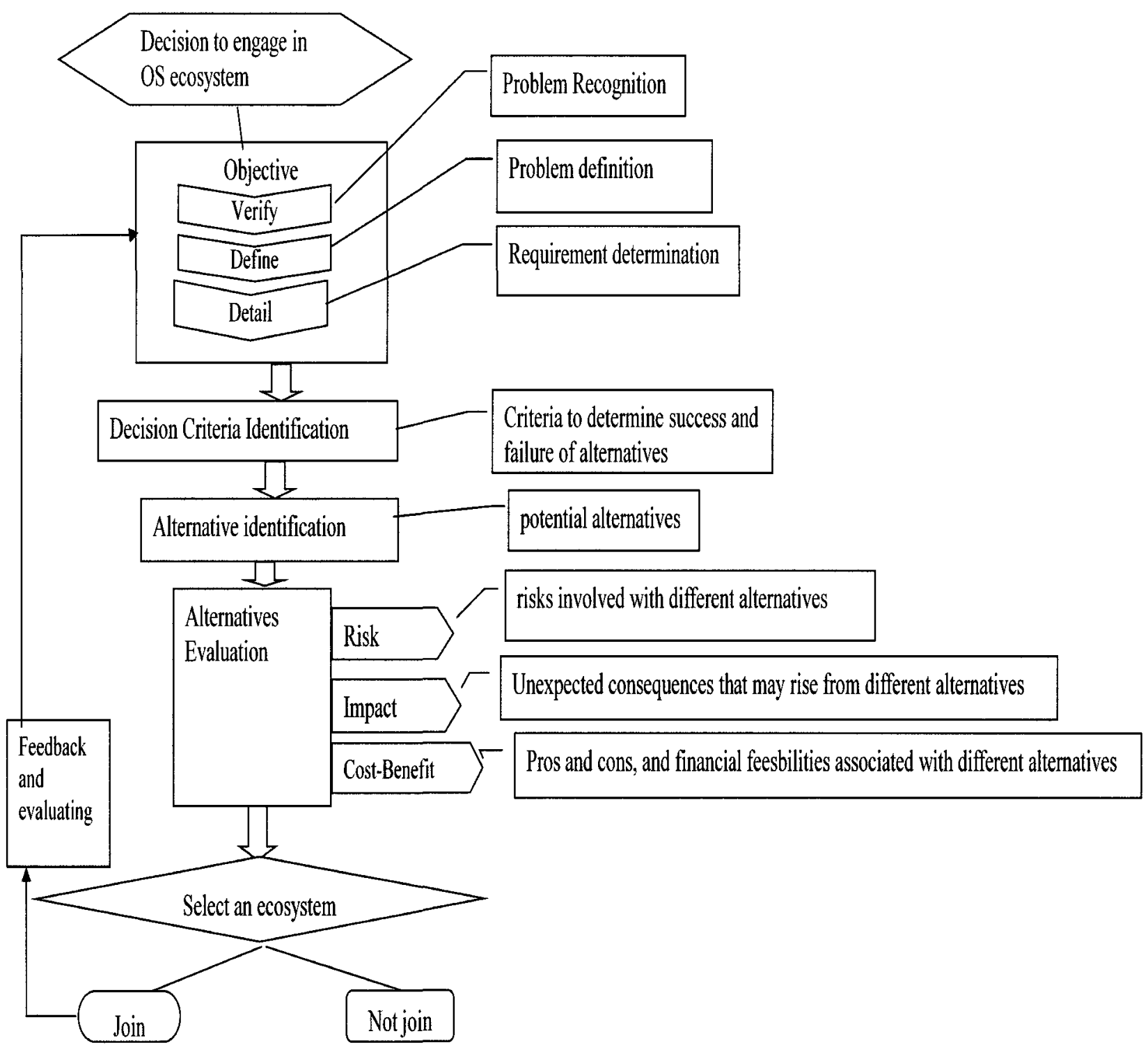

Figure 2: Rational decision making model 


\subsubsection{Habitat Selection in Ecology}

The existing metaphors in ecosystem literature fell short in terms of analogizing firms due to two main reasons: (1) they do not reflect firms' ability to access different ecosystems; (2) they disregard firms' decision making powers to evaluate and choose an ecosystem. To solve this shortcoming this research discovered the concept of habitat selection in avian ecology close analogy to firms seeking OS ecosystems to participate in. Avian habitat selection studies how migrating birds explore and evaluate different habitats along their migration path and choose one to nest in.

"Ecology" is defined as identifying the underlying mechanisms that result in patterns of distribution and diversity of species. These mechanisms are commonly categorized in literature as random dispersal, differential mortality, and habitat selection.

"Habitat selection" theory emphasizes on the ability of species to disperse and colonize in habitats with the indications of the highest level of species fitness. Habitat selection results in patterns of distribution that are a function of spatial redistribution of individuals (Leibold et al. 2004).

In other words habitat is considered a main contributor to fitness of members of species (Franklin et al. 2000) and as a result natural selection favours the ability for individuals to recognize habitat quality and choose habitats with the highest quality (Clark \& Shutler, 1999). "Habitat fitness potential" refers to the noted role that habitat plays in the fitness of members of species, which offers the foundation for habitat quality (Garshelis, 2000).

A main stream of "avian habitat selection", studies the relationship between the attractiveness of 
habitat and its quality, and come to a conclusion that there is a positive relationship between habitat preferences and habitat quality (Sergio \& Newton, 2003).

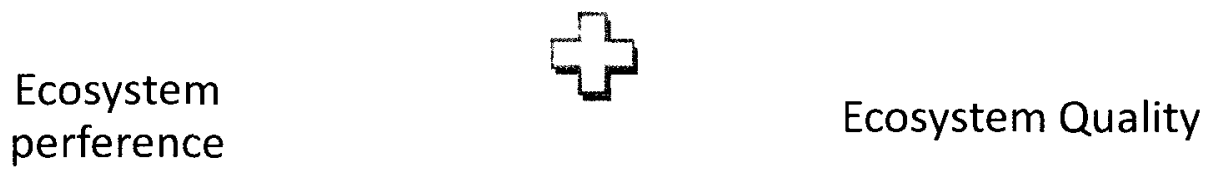

Figure 3: Ecosystem preference and Ecosystem quality

\subsubsection{Techniques and sources of information in avian habitat selection}

Kristan et al. (2007) categorises the following three techniques and their corresponding sources of information that birds rely on in order to evaluate and choose habitats for different purposes such as foraging and breeding:

- Prompt feedback

- Utilizing past experiences

- Inquiring public information 


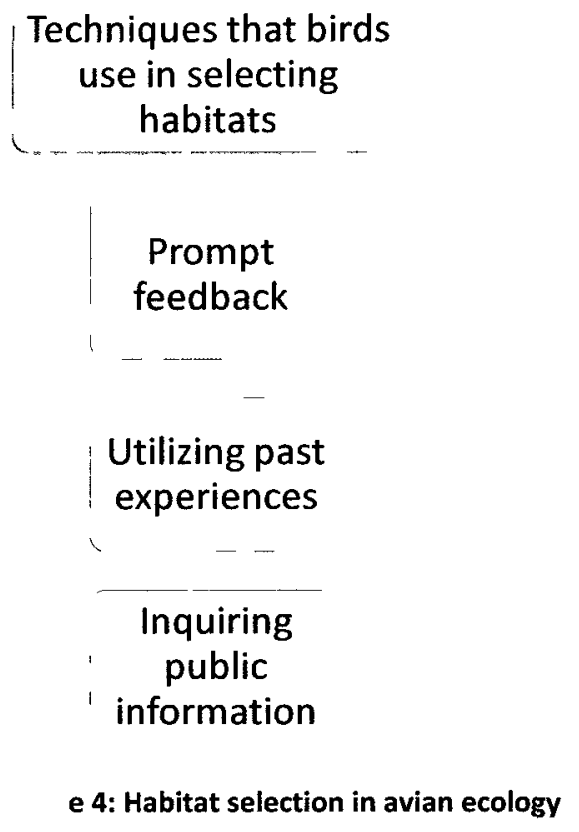

\section{Prompt feedback}

Prompt feedback is based on a trial and error mechanism that birds use in selecting habitats for purposes such as foraging where feedback about the accuracy of their selection is received promptly and can be adjusted accordingly. For instance birds can leave a patch as soon as they experience low resource levels.

\section{Past experience}

In choosing a habitat for the purpose of breeding, birds often rely on lessons learned from their past experiences, for instance abundance or absent of predators or conspicuous can be indicators of whether or not a habitat is suitable for breeding. 


\section{$\underline{\text { Public information }}$}

In some studies ecologists found that birds can obtain public information regarding the fitness of the habitat from other birds that are already present in the habitat (Ahlering and Faaborg, 2006). This use of the term "public information" is far from its commonly used meaning and might cause confusions. Therefore it will be substituted with "consult existing members".

\subsection{Lessons Learned}

The business ecosystem literature predominantly emphasize on the significance of participating in business ecosystems in order to ensure firms' survival, and come short in defining the notion of involvement and choosing business ecosystems from firms' perspective.

Literature fails to effectively address the evaluation of health of business ecosystem in general and OS ecosystems in specific, in terms of perspective of different roles as well as operational measures that can be readily used. Instead, existing literature tend to focus on long term performance measures rather than metrics to monitor health of ecosystem at any stage of growth.

Additionally, literatures discuss monetary metrics and factors and come short in measuring nonmonetary health factors such as the role that relationships and dynamics among ecosystem members plays in overall health of ecosystem.

The notion of OS ecosystem and its related attributes have not been well defined, for instance it is not clear what factors separates an open source ecosystem from open source communities. While the latter is for the mere purpose of contributing or using the code developed in the open source project that creates the ecosystem platform, firms join open source ecosystems to build 
and improve their business models while co-creating value with other ecosystem players. Therefore, OS ecosystem as addressed in the context of this research is defined as:

"Network anchored around an OS foundation, of not only individuals (OS communities) but also commercial organizations that pursue different business models and requirements while contributing back to the foundation, other organizations and OS ecosystem as a whole."

In addition, there is not sufficient research on OS ecosystem growth strategies at early stages focusing on attracting new members from different categories, and subsequently common scenarios that result in engagement of firms in an early-stage OS ecosystem have not been identified. In order to explore the birth and formation of OS ecosystem, this paper refers to the role of OS ecosystem initiator as:

"The main corporate entity in charge of formation of $O S$ foundation, and transformation of a sponsored OS community into an OS ecosystem"

Finally, Literatures come short in addressing the decision making process those firms conduct in order to choose OS/business ecosystems. 


\section{Research Question}

This research will answer the following questions through examining an early-stage OS ecosystem:

- How young firms chose an early-stage OS ecosystem?

Additionally this research provides insights on following sub-objectives:

- Do firms utilize the techniques suggested in ecology literature in choosing an OS ecosystem?

- What are common scenarios that lead to firms' engagement with the early-stage OS ecosystems?

- What are the attributes of an OS ecosystem considered by young firms in making their choice as well as some of the common techniques and available sources of information young firms rely on in evaluating these criteria?

\subsection{Significance of research question}

Young firms' realization of the value propositions offered by OS ecosystems and the advantages of involvement at earlier stages of ecosystem growth is increasing, which magnifies the importance of choosing ecosystem that not only provide immediate values but also promises the long-term business return. Therefore, identifying the drivers and evaluation process that lead to young firms' decision to participate, despite the lack of firm indicators and the uncertainties as common characteristics of these ecosystems at such early stages, is empirical. 
On the other hand, more young firms are exploring opportunities around sponsoring OS projects for the purpose of initiating OS ecosystem anchored around them through adopting the role of keystone. Ecosystems that succeed and evolve in long term such as Apple consciously attract and recruit a full community of strategically suitable partners from these early stages on ward. Since the growth and marketing strategies that such young firms adopt at early stages to acquire key members and form the foundation of ecosystem play a defining role in long term sustainability, their knowledge of how prospect members find OS ecosystems and what attributes they consider in making their choice is empirical.

Considering that ecosystems cannot attract these key partners and actors unless they provide compelling reasons and competitive advantages over other ecosystems, understanding why different players prefer to participate in an ecosystem over others enables keystones strategize accordingly.

It is important to note that different players in an ecosystem consider different criteria in joining and choosing a specific ecosystem based on their role, and personal agenda. While some aspects of an ecosystem play an imperative role in one players' decision making process to join, it might not be as significant for other players. 


\section{Theoretical Framework}

This research uses the following two frameworks, with the second framework embedded in the

first one: (1) Rational decision making model; (2) Techniques that birds rely on in choosing a

habitat.
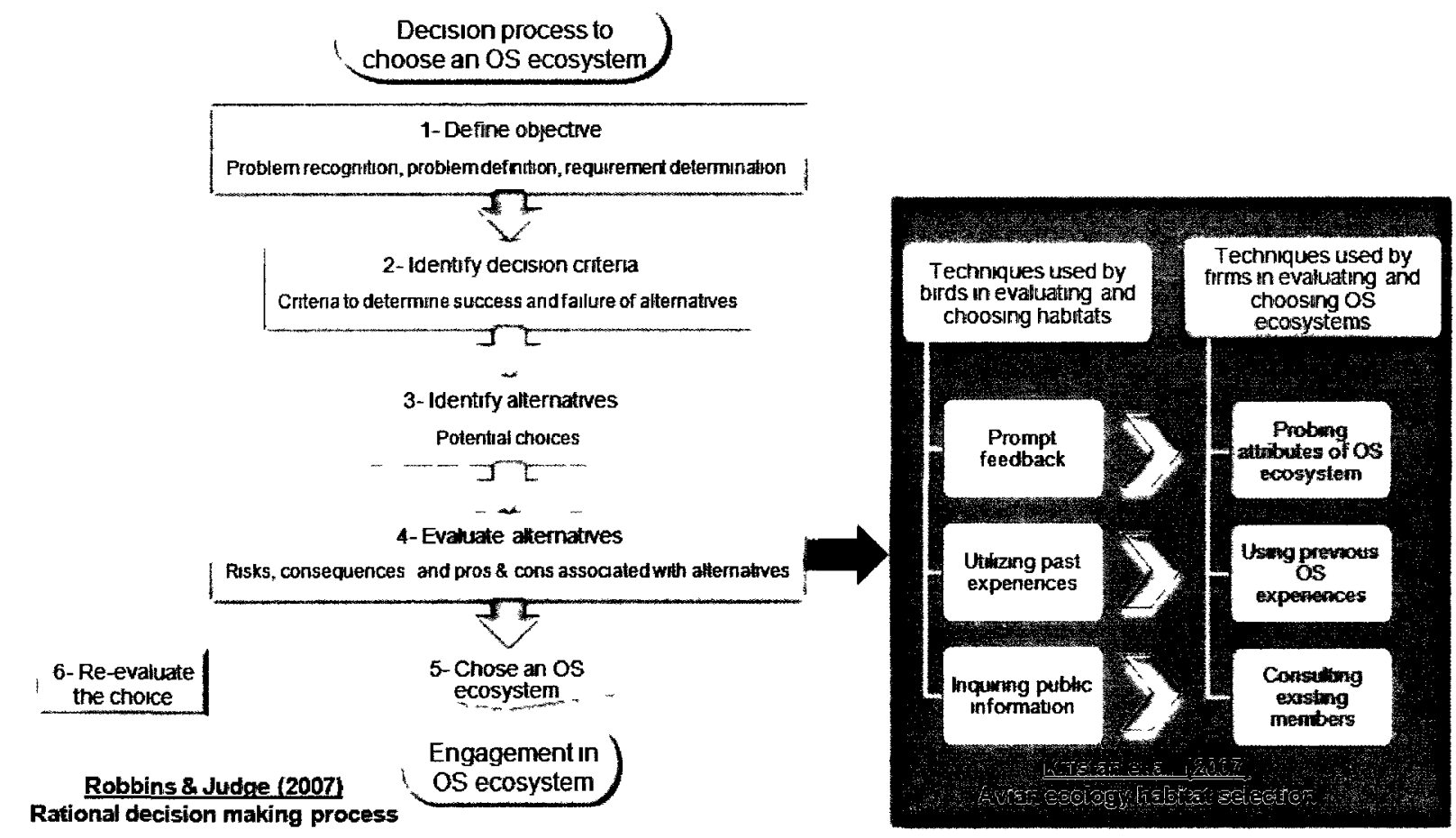

Figure 5: Theoretical framework 


\subsection{Rational Decision Making Model}

Since this research studies the decision making process that firms practice to choose and engage in open source ecosystems the main frame work used in this research is based on the rational decision making model. While this model covered subjects from firms' objectives in engaging in ecosystems to how they were informed about the existence of the ecosystem, the focal point was on the techniques and sources of information that these firms used to in order to make a decision about their final choice.

Choosing an OS ecosystem in a sense is a decision-making process conducted by firm in pursue of achieving business goals or solving a dilemma. This research will make an attempt to observe and discern patterns that reflect how young firms make their decisions to choose and participate in OS ecosystem. It is imperative to recognize that young firms are faced with ecosystem choices that differ not only in terms of overall quality but also in terms of fitness with firm business requirements.

This paper will study how and to what extent sample of young firms in an early-stage OS ecosystem followed the steps in rational decision making model originated from Robbins \& Judge (2007) in order to choose the subject OS initiative.

\subsection{Habitat selection}

The main focus of this research is on the step four of rational decision making model that explores evaluation of alternatives by decision maker. 
Since the existing analogies in ecosystem literature fell short in analogizing firms as entities with mobility to access wide range of ecosystems and decision making power to evaluate and/or an ecosystem; the habitat selection in avian ecology, which studies how migrating birds explore and evaluate different habitats along their migration path and chose one to nest in, was discovered to be a close analogy to firms used in this study.

In order to apply this analogy, firms can be thought of as species that are placed in ecosystems through three mechanisms as originated from ecology: random dispersal, differential mobility, and habitat selection. These mechanisms can be interpreted in the context of firms choosing an OS ecosystem:

1-Random dispersal: firms are present in the ecosystems following a series of random events and not based on their preferences (for instance they have been initially part of the value chain that later developed into a business ecosystem and they maintained their role or evolved into a new role during the process). This factor is driven by past dependencies among firms where history defines where companies are at any point of time.

2-Differential mortality: firms are present in the ecosystem as a result of winning over a niche from competitors that previously shared or solely occupied the niche. This factor is dependent on the survival rate of firms, since firms have different life spans; the ones with longer life span have the chance to be present in ecosystem for a longer period of time.

3-Habitat selection: firms are present in the ecosystem because they studied the ecosystem and found the best fit prior to joining.

This research considers the last scenario as the most common method in ecosystem selection among the three, and therefore will be focused on habitat selection. 
In applying habitat selection analogies to ecosystem selections by firms, it is important to consider while many species selection power is limited to few habitats due to their limited geographical mobility, firms have access to a wide range of ecosystems to chose from. Therefore this paper will focus on avian habitat selection, since birds are the ideal subjects for such studies due to their high mobility and migration abilities; enabling them to select a specific habitat while passing over an enormous range of environments.

\subsubsection{Techniques used in evaluating and choosing an OS ecosystem}

Kristan et al. (2007) identifies three techniques in evaluating habitats and examples of their corresponding sources of information that birds use in choosing a habitat: prompt feedback, past experiences, and public information. This research analyzes the collected data of interviews in terms of utilization of business equivalent practices of these techniques and their corresponding information sources by firms in choosing an early-stage OS ecosystem. Subsequently each of the techniques needs to be translated in the context of practices common to firms to evaluate their choice of early-stage OS ecosystem.

\section{Prompt feedback $\sim$ probing attributes of OS ecosystem}

As birds use a trial and error mechanism to gain information on quality of a habitat; firms may use variety of probing techniques in order to gain information on the quality and fitness of different attributes of an early-stage OS ecosystem. Researcher stipulates that these probing techniques could include common practices by firms such as trial of technology, and making inquires to OS community.

\section{Using past experiences using previous OS experiences}


As birds often rely on past experiences such as abundance or absent of predators, in choosing a habitat; firms may rely on their past experiences with OS initiatives in choosing an early-stage OS ecosystem. Researcher stipulates that these past OS experiences could include existence of specific role players with significance to the firm, such as competitors and complementors in the ecosystem.

\section{Inquiring public information consulting existing members}

As birds rely on public information received from other birds in choosing a habitat; firms may consult of existing members in OS ecosystems on their experience and satisfaction with the OS ecosystem in order to gain information about its quality.

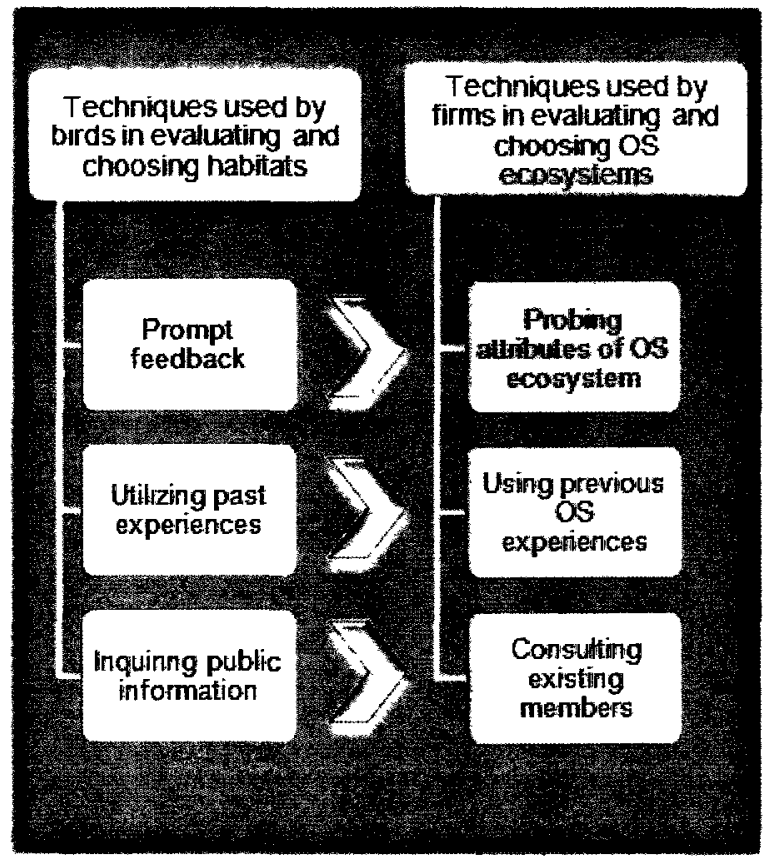

Figure 6- Framework of techniques used by firms to choose and evaluate OS ecosystems 


\subsubsection{Sources of information used in evaluating and choosing an OS ecosystem}

It can be expected that firms use number of sophisticated techniques to evaluate OS ecosystem, and number of sophisticated sources of information to apply these techniques to. It can also be predicted that result of the research will include the common sources of information that firms use to evaluate ecosystem as stated in literature, such as OS project websites, code documentations, developers' log and etc...In addition to these sources of information, a keen interest of this research is identifying sources that inform firms of characteristics of OS ecosystem that goes beyond the OS community and technology it is anchored around. An example of such sources expected to be considers by firms is existence of other players. In addition to examining ecosystem in terms of presence of qualified suppliers and distributors, the presence of companies that target the same customers by providing complementary products and services should be also taken into consideration.

Literature on avian ecology state that the speed at which individuals are able to judge the accuracy of their choice of habitat in terms of factors such as breeding is very slow which makes it more complex and significant compared to decisions such as foraging. The same statement may be true in case of OS ecosystem selection; for instance, feedback about the accuracy of an open source code integration decision is received in a faster pace from the development team as well as customers and can be adjusted quickly. In contrast, there is intrinsically less information for the selection of the ecosystem for purposes such as increase in revenue and there will often be time lags between the time when a choice is made and the time when the consequences of the choice are realized.

Much like habitat selection, while the information available to firms in choosing OS ecosystems for the purpose of short term performance benefits can be obtained from above resources (e.g. 
Existence of niche players, or competitors in the ecosystem, or the quality of platform

development team), the future conditions that determine the long term return of participating in ecosystem and success of the ecosystem as a whole cannot be observed directly. 


\section{Research Design}

Open source ecosystems provide an interesting context for analyzing how young firms get involved with ecosystems in general. This is due to the fact that the open source nature of ecosystem platforms provide the opportunity for some firms to emerge through building a business model as a result of involvement with the ecosystem, and others to utilize the platform as the product of their choice by making a decision to be actively involved with the ecosystem that provides related services and support.

Open source product development depends on the efforts of a large number of geographically dispersed individual from variety of firms and communities and provides a higher level of visibility, which leads to a faster and wider spread growth of ecosystem. Also, other characteristics present in an open source ecosystem such as extreme openness and public right to usage and distribution create means for firms to study and observe the ecosystem beyond its open source community and get involved with the ecosystem through an educated decision making process which is the objective of this research.

\subsection{Unit of analysis}

The unit of analysis of this research is responses to interviews with young firms involved in a sponsored OS community on the verge of transforming into an OS ecosystem.

The careful selection of an early-stage OS ecosystem was critical achieving the objective of the research due to main three reasons. The fact that ecosystem is at early stages can decreases the 
possibility that firms would be selecting the ecosystem mainly due to the brand name established in the market and therefore do not utilize a sufficient decision making process efficiently. Also it is important that ecosystem is anchored around a young platform which decreases the possibility that firms' decision to participate in ecosystem is solely base on the branded OS project and platform and other attributes of ecosystem are not taken into consideration. Additionally the fact that ecosystem is at young can interpret into high level of participation of new member acquisition activities.

\subsection{Respondent criteria}

Given this research theoretical interest in how young firms make a decision to be involved in ecosystems for variety of purposes and use; the respond criteria were considering firms with different roles in the OS community and also having the choice in making the decision to be involved with different aspects of the OS project.

Therefore the selection of interviewees had to be done in case by case format based on their support and active involvement in the OS community rather than their mere sense of present in environment.

In summary, a sample of nine firms with differing roles, their objectives and decision making process in participating in the different aspects of network, as well as their OS selection methods were investigated in this research. The selection of these nine companies was made through studying the network of firms anchored around the sponsored OS project using references to 
literature such as Bloom (2008) and the PARTS frameworks to map the network of project participants, besides consulting the current community sponsor.

The last criteria ruled out some of the actors such as resource providers and competitors who were not involved in the network initially by choice. However in case of resource providers some open source communities despite having no choice in their product components to be integrated into OS platform, at some point made a conscious decision to be involved with the network through providing support or related products in form of plug-ins, etc...

\subsection{Time period}

While this research was conducted from summer 2010 to winter 2011, Interview data that was collected during the term $\mathrm{f}$ research covered firms' decision to engage in OS project in the span of 2007 to 2011.

\subsection{Research Method}

The research method used in this research consists of six steps: literature review; selection and examination of selected OS community; developing interview question; conducting interviews, analyzing results; and conclusion and data presentation. 


\subsubsection{Literature review}

Literature review as mentioned in previous sections was primarily focused on two objectives:

1. Main stream subject: Literature review on the research subject of ecosystems was conducted, covering; from business ecosystems, their health and attributes, to open source ecosystem, and its related aspects.

2. Theoretical frameworks: Literature on two different streams of decision making at the core and avian ecology as a subdivision, were reviewed in order to create the conceptual frameworks of the research.

\subsubsection{Selection and examination of OS community}

In this step an OS community that matched the criteria mentioned in research design in terms of a network striving to birth into an OS ecosystem anchored around a young platform was selected. Then, the project history, platform and OS community, as well as the current members and their engagement in different aspects of project were examined.

Following are a summary of activities undertaken in this step:

- Followed the strategies and steps provided in literature in mapping business ecosystem

- Define project sponsor's ultimate intended goal of creating the ecosystem

- Define various parts of ecosystem including the players and environmental conditions. 
- Collected primary data by reviewing the selected OS community website, blogs, news groups, and selected OS ecosystem dynamics, players and their roles

- Consulted available academic and business reference to finalize the sketch

\subsubsection{Developing interview questions}

In this stage a preliminary set of interview questioners were created based on previous research from literature, and consulting faculty. Then, feedback was obtained from business and academic references firm and a partner to finalize questionnaire.

The rational decision making model was used in order to create a logical fellow in how questions were organized; optimizing responses to reflect the firms decision making process thoroughly. Therefore, questions were organized based on a fellow of below subject categories:

- Interviewees' introduction and involvement with OS project

- Firms' introduction and involvement with OS project

- Firm's decision to be involved with OS project

- Evaluation and selection of OS project

Since the questions were addressed to different type of actors in the ecosystem (e.g. customers, partner, etc...) questions were semi-structured. The initial interview guidelines were updated and enhanced over time according to the results of previous interviews.

\subsubsection{Conducting interviews}


The selection of interviewees was based on their support and involvement in the project rather than their mere sense of present in environment. Interviews were conducted with participants from different categories of members identified in OS community. The participants were selected from the developer and user mailing lists and as per business resources (e.g. the management of community sponsor) suggestions. Most of the interviewed individuals held strategic decision making positions in the firms such as CEO and founders of the firms.

Semi-structured on the phone interviews each lasting between $0.5-1$ hour, were conducted; focusing on providing the chance for interviews to have a natural flow and reflect the stories and agendas of interviewees, and state opinions.

\subsubsection{Analyzing results}

In this step data from interviews were content analyze and cross-tabulated to show findings across different interview responses. Then, similarities and differences across interview responses and possible reasons behind them such as firms' role in ecosystem and nature of their business were identified. Also, scenarios and drivers that initiate firms' involvements in open source ecosystems and the effect that open source nature of platform has on firm's decision making process to join the ecosystem were identified. 


\subsubsection{Conclusion and data presentation}

In this step the results were arranged in a chart to show:

- Sources that informed firms about the existence of OS project \& firms objectives/ requirements

- Attributes of an OS project considered by firms \& techniques for examining these attributes

Then the techniques used in evaluating OS ecosystem were compared with habitat selection model in ecology. Finally, the implications for managers in form of a check list to be used in choosing an early-stage OS ecosystem.

\subsection{Data Collection}

The data sources used in this research fall into two main categories:

- Firm and ecosystem data: Some secondary sources such as companies' homepages, blogs, mailing lists, user support groups etc. were used to gather information on ecosystem, firms, and their involvement with ecosystem. This provided information about the communities inside the ecosystem, the general environment of the ecosystem, and the overall perception of the outsiders about ecosystem.

- Interviews with firms: A total of nine semi-structured on the phone interviews each lasting between $0.5-1$ hours, was conducted, which included questions as outlined in section 6.2.1. 


\section{Results}

This chapter outlines the result of the steps outlined in research method section of this paper.

\subsection{Selected OS community: BigBlueButton}

BigBlueButton (BBB) OS community was selected as the Subject OS community, since it did not only match the criteria mentioned in research design in terms of:

- An OS community striving to birth into an OS ecosystem: through activities and initiatives such as transferring control and management from a single sponsoring firm to a foundation

- An OS community anchored around a young platform: BBB software with less than 3 years of age is considered a very young platform compared to similar products in market

- An early-stage OS ecosystem: BBB fits the definition of an early-stage OS ecosystem not only due to the activities around creating an OS foundation, but also the fact that its network of firms are still limited and is actively acquiring more key players. In addition the value propositions of the ecosystem are being defined in order to create a whole package that attracts prospect participants.

The other factor was the fact that BigBlueButton project as a classic example of academic spinout is endorsed by Carleton University, which made the study on its collective more appealing and relevant. 


\subsubsection{Technology and industry}

To summaries, BigBlueButton is an integrated and highly compatible web conferencing system. Web conferencing market is considered a very fast pace market segment, going through disruptive changes and innovations in last few years. For instance, with increasing popularity of smart phones such as iPhone for e-learning purposes, introduction of the new iPad might lead to a disruption in web-conferencing market; in a sense that only products (and their respective companies) which catch up with these new disruptions in a timely manner will survive the face of competition. Also, it seems that browser based tools are gaining popularity over software based tools, expanding their market share consequently their total pie.

\subsubsection{History}

BigBlueButton was sprouted as a school project in Carleton University. The project started as the TFN 100 (see www.talentfirstnetwork.org for the early history of the project, in particular: http://www.talentfirstnetwork.org/wiki/index.php?title=TFN-100). The project was then called Blindside and released as an open source project. Blindside Networks was created later and the name of the project changed to BBB. Blindside Networks which promoted BBB as an open source project and made it available for public to try or take part in through the company website: www.bigbluebutton.org. Blindside Networks is a for-profit organization that supports the BigBlueButton OSS project and manage the OS community and network that is formed around the project. By promoting the OS project the overall productivity is improved through maximizing how available resources (e.g. OS components, expertise and knowledge of 
committers and volunteers, etc...) are utilized in order to improve the performance of product and services.

\subsubsection{Network support and performance}

Blindside Network has utilized different channels in informing firms in the network of industry news and relative ideas and technologies through postings in their blog at: http://bigbluebuttonblog.blogspot.com/

The number and frequency of postings in mentioned blog can be an indication and measure of delivery of innovation.

In addition to the blog BigBlueButton website provides developers, who wish to contribute, extend or utilize the project with a well-organized support system of overviews, installation videos, and tutorials. The quality of this documentation that provides support to any individual or firm interested in setting up a local BigBlueButton server and understanding its architecture can be analyzed as a factor of delivery of innovation. For instance how the installation manual corresponds to different needs of different levels of members, whether experts or novice, etc... (Installation manuals are available in VMware and Ubuntu for novice users as well as source code for more savvy users).

The other available resource is online discussion group where public can post their questions and received responds from community- accessed via the link below: http://groups.google.com/group/bigbluebutton-dev/topics?gvc=2 
The quality of support is evident at the turn around on responses of questions posted on discussion group and number of threads available. Also the community uses a public issue tracking system and source code repository, which can be another indicator of project efficiency.

In an attempt to foster innovation in ecosystem; on July 12, 2010 blindside network initiated attempts to establish an open source foundation and making its restricted proprietary company assets available freely and openly. These assets play the role of the platform for creating the building blocks that innovative products and services are built upon by others in network and will ultimately improve delivery of innovations in BigBlueButton ecosystem and impact the type of copy right and limitations of usage and proprietorship. For instance, as of BigBlueButton 0.7, the license for the desktop sharing module will be Limited GNU Public License V3. In addition, Blindside Networks attempts to improve how effectively these building blocks are shared through providing direction and support to members in utilizing building blocks and coming up with innovative ideas that lead to complementary products and services. It also facilitates the allocation and distribution of network members' experiences and expertise on how to extract value from the network in order to deliver innovation.

\subsubsection{Academic perspective}

Based on the above preliminary study BigBlueButton community is an OS community since it consist of group of developers and users with a common interest in BBB OS project, and interact with each other in order to share knowledge and resolve issues in regards with the project. Soon this OS community will benefit from an OS foundation as a formal, legal, non-profit foundation to help manage its governance and assets (West \& O’Mahony, 2008). 
Also it can be concluded that BigblueButton is a sponsored OS community since one (or more) corporate entities, in this case Blindside Networks controls the community's short- or long-term activities (West \& O’Mahoney, 2008).

An OS ecosystem as used in the context of this research is a network anchored around an OS foundation, of not only individuals (OS communities) but also commercial organizations that pursue different business models and requirements while contributing back to the foundation, other organizations and OS ecosystem as a whole.

Considering the role that BlindSide Networks plays as a main corporate entity in charge of formation of OS foundation and transformation of a sponsored OS community into an OS ecosystem, it can be titled BBB OS ecosystem initiator.

BigBlueButton network of firms can be also considered as an early-stage OS ecosystem where OS foundation is being formed and initial key members are acquired and identified in order to implement and define ecosystem value propositions.

\subsection{BigBlueButton network of firms}

In order to obtain an overall picture of the activities and firms involved in BBB project, the CEO of Blindside network Blindside Networks, Fred Dixon, was consulted, he emphasized that the project has reached a stage that is focusing on the ecosystem of firms around the project and ways to expand this ecosystem by acquiring firms that are interested in involvement with different aspects of the project. In order to study the current state of the network of firms involved in the project one needs to identify these firms and the nature of their involvement. This 
task was achieved by referring to "Mailing list for BigBlueButton Users", "BigBlueButton-dev group", and consulting Blindside Networks.

In creating a scheme of the current network of firms, it is important to note that ecosystems incorporate a broader range of environments with diverse sets of players and actors (e.g. complementors, arbitrators, academia, etc) compared to the traditional framework with only three major role players of competitors, suppliers and customers.

Bloom and Dees (2008) suggest a step by step instruction in creating an ecosystem map for social enterprises which can be applied to mapping BigBlueButton network to some extent.

According to Bloom and Dees the first step in creating an ecosystem map is to define the focal organization's ultimate intended goal of creating the ecosystem, and series of steps that will lead to that goal. It is important to note that focal company is the company that is analyzed and studied through the mapping and not necessarily the keystone or the central player.

Hence BigBlueButton Inc. and Blindside Networks as the company behind the foundation need to address the following question:

"What company is trying to achieve by creating the ecosystem?"

The answer to this question is somewhat explained in company's vision statement on the BigBlueButton Inc. website.

"Our vision is that starting a web conference should be as easy as clicking a single metaphorical BigBlueButton. As an open source project, we believe it should be easy for others to embrace and extend. And while web conferencing means many things to many people -- our focus is to make the best web 
conferencing system for distance education."

As stated above the ultimate goal is perfecting the product and services offered based on BigBlueButton tool set, while facilitating and promoting ecosystem participation.

The second step is identifying the various parts of ecosystem including the players and environmental conditions. In order to simplify the mapping process it would be easier to categorize the players. The paper is suggesting six roles applicable to social ecosystem from which the followings are relevant to this research: Complementors -which include initiator, partners, related service providers and contributors; customers; suppliers; and competitors.

These categories of players are also suggested by Brandenburger \& Nalebuff (2006) in their PARTS frame work. In applying PARTS frame work to BigBlueButton, the four main categories of players consist of subcategories as following and firms as illustrated in Figure 7.

- Complementors

- Initiator

- Partners

- Related service providers

- Contributors

- Customers

- Suppliers

- Competitors

The remaining four elements of PARTS besides Players are: Added values, Rules, Tactics, and Scope. 
The Added value that firms in BigBlueButton project bring to the game is analyzed in form of their contributions and level of involvement in activates surrounding different aspects of the project. Examples of these contributions are: sponsorship activities by initiator and partners, code contribution by suppliers and contributors, etc...

An example of the rules in BigBlueButton project can be described as complying with the open source licensing. Tactics represent players' perception of the game and how they play it accordingly and can be specific to firms in BigBlueButton project; however one example is the strategies and the visions that initiator and partners are deploying to evolve the project into an ecosystem. Finally, scope (boundaries of the game) of BigBlueButton project is currently higher education but as scopes can be expanded the future opportunities in enterprise market is being explored by the project sponsors. 


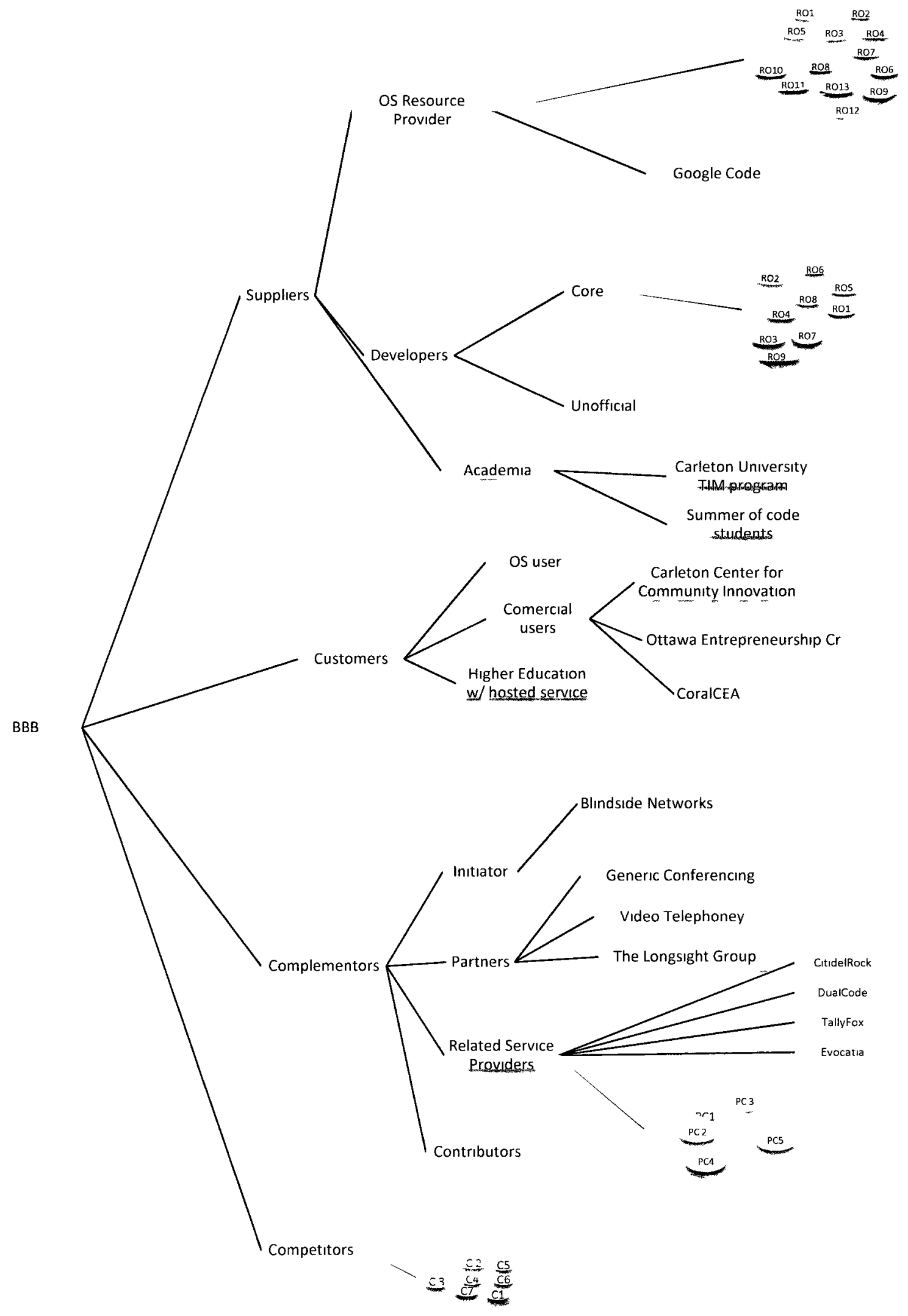




\subsubsection{Resource Providers (suppliers)}

Also known as suppliers, provide different resources from financial, human, knowledge, networking, to technological expertise. In BigBlueButton network this category of players consists of: OS resource providers, official developers, unofficial developers, and academics.

\subsubsection{Open source resource providers}

BigBlueButton system uses fifteen OSS components most of which are built upon components provided by other communities and companies. In that sense component provider to these companies are connected to BigBlueButton business ecosystem, which could be considered as an area for future growth.

Bloom and Dees (2008) suggests that this category includes brokers and intermediaries that channel these resources to members in ecosystem. However the latter is commonly considered a separate category in other literature which is more suitable for the purpose of BigBlueButton ecosystem mapping. For instance Ghostscript can be downloaded from cs.wisc.edu and sourceforge.net as well as their website. Also, source code for BigBlueButton open source project is hosted at Google Code- http://code.google.com/p/BigBlueButton/

The corresponding key for open source component providers is: $\mathrm{RO}$ 


\begin{tabular}{|l|l|l|}
\hline Key & OSS components providers & Components \\
\hline RO1 & Apache & ActiveMQ and Tomcat \\
\hline RO2 & Asterisk Java & Asterisk Java \\
\hline RO3 & Digium & Asterisk \\
\hline RO4 & Adobe & Flex SDK \\
\hline RO5 & Artifex & Ghostscript \\
\hline RO6 & Spring Source (a division of VMWare) & Grails \\
\hline RO7 & ImageMagick Studio LLC & ImageMagick \\
\hline RO8 & Oracle & MySQL and OpenOffice \\
\hline RO9 & Nginx & Nginx \\
\hline RO10 & Open source flash & Red5 \\
\hline RO11 & SWFtools & SWFtools \\
\hline RO12 & Canonical & Ubuntu \\
\hline RO13 & ConnectSolutions & Xuggler \\
\hline
\end{tabular}

\subsubsection{Developers;}

There are two categories of developers involved in BigBlueButton project.

Core developers: There is a core team of developers that work together on each BigBlueButton release. The corresponding key for developers is: RD

Unofficial developers: There are many "unofficial" developers on the BigBlueButton-dev mailing list (which has over 600 members). Examples include a team in Poland (Piotr and friends) who are integrating BigBlueButton with their own application and Victor Taranenko who has added support for maven. 
Table 5: List of BigBlueButton core developers

\begin{tabular}{|l|l|l|}
\hline \multirow{2}{*}{ Key } & Partial list of core developers & Country \\
\cline { 2 - 4 } & Developer & Canada \\
\hline RD1 & Richard Alam & Canada \\
\hline RD2 & Dennis Zgonjanin & Canada \\
\hline RD3 & Omar Shammas & Canada \\
\hline RD4 & Fred Dixon & Louisiana \\
\hline RD5 & Jeremy Thomerson & Ecuador \\
\hline RD6 & Marcos Calderon & China \\
\hline RD7 & Chen Guangtao and Xie Yan Qing & Brazil \\
\hline RD8 & Tiago Jacobs & France \\
\hline RD9 & DJP & \\
\hline
\end{tabular}

\subsubsection{Academia}

Academia includes two groups of: Summer of code students, and Carleton University: TIM program. 


\subsubsection{Competitors}

This category is defined as organizations that compete with BigBlueButton for recourses and those that compete to serve the mutual market segments. Below are examples of companies that compete with BigBlueButton in providing web conferencing products and services to educational institutions and other organizations.

The corresponding key for competitors is: $\mathrm{C}$

Table 6: BigBlueButton competitors

\begin{tabular}{|l|l|l|}
\hline \multirow{2}{*}{ Key } & Competitors & Product \\
\cline { 2 - 3 } & Company & Blackboard \\
\hline C1 & Elluminate & Blackboard \\
\hline C 2 & Wimba & Webex \\
\hline C 3 & Cisco & IVCi Presenter \\
\hline C4 & VCl-Group & Mediasite \\
\hline C5 & Sonic Foundry & Centra \\
\hline C6 & Saba & DimDim \\
\hline C7 & DimDim & \\
\hline
\end{tabular}

\subsubsection{Complementors}

These players are organizations or individuals that facilitate BigBlueButton ability to achieve its goals and visions. This category consists of initiator, partners, contributors and related service providers. 


\subsubsection{Contributors}

These players are 20 individuals from academia and development who contribute to BigBlueButton project by creating and editing downloads wikis, issues, etc...

\subsubsection{Initiator}

In the context of this research initiator provides the highest level of contribution in the network, in order to establish the OS foundation and subsequently the OS ecosystem. As well as providing supports in platform development and to other firms and entities in the network, it plays a major role in managing the OS community and setting the future vision and direction of the ecosystem. As mentioned earlier, in BigBlueButton network, BlindSide Networks can be considered as the initiator.

\subsubsection{Partners}

In the context of this research partners provides the second highest level of contribution after the ecosystem initiator. Partners not only provide supports in platform development and to other firms and entities in the network, they also often provide insights and assistance in managing the OS community and setting the future vision and direction of the ecosystem.

- Generic Conferencing: Commercial hosting provider to colleges and universities

- The Longsight Group

- VideoTelephony 
The corresponding key for partners is: PP

Table 7: BigBlueButton partners

\begin{tabular}{|l|l|}
\hline Key & Partners \\
\hline PP1 & Generic Conferencing \\
\hline PP 2 & The Longsight Group \\
\hline PP 3 & Video Telephony \\
\hline
\end{tabular}

\subsubsection{Related Service Providers}

These are niche players that provide innovative services based and built on the platform by focusing on specific market segment. They do not provide the same level of contribution in the network as ecosystem initiator and partners, however usually play a significant role in development activates and user support. This category also includes internet service providers that host BigBlueButton locally for universities and colleges (e.g. http://evocatio.com/ (they have started hosting BigBlueButton for the TikiWiki project)

The Following companies provide commercial support or customization, integration, and additional features beyond the open source project.

The corresponding key for related service providers is: $\mathrm{R}$ 
Table 8: BigBlueButton related service providers

\begin{tabular}{|l|l|}
\hline Key & Related service providers \\
\hline R1 & CitidelRock \\
\hline R2 & DualCode \\
\hline R3 & TallyFox \\
\hline R4 & Evocatia \\
\hline
\end{tabular}

Some open source projects have integrated BigBlueButton in their products. The corresponding key for product complementors is: PC

Table 9: OS projects with BBB plug-ins

\begin{tabular}{|l|l|}
\hline Key & OS project with BBB plug-ins \\
\hline PC1 & Drupal \\
\hline PC 2 & Moodle \\
\hline PC 3 & Sakai \\
\hline PC4 & Tiki \\
\hline PC5 & WordPress \\
\hline
\end{tabular}

\subsubsection{Customers}

These players include customers, open source users and others who benefit from using BigBlueButton system to serve their web conferencing needs.

They are categorized in three groups: 


\subsubsection{Open Source Users}

Anyone can easily download and set up a BigBlueButton server from the website.

\subsubsection{Commercial Users}

These customers use a version of BigBlueButton that is customized, integrated, or/and has additional features beyond what's offered in open source version.

The corresponding key for commercial users is: CC

Table 10: BigBlueButton commercial users

\begin{tabular}{|l|l|}
\hline Key & \multicolumn{1}{|c|}{ COMMERCIAL USERS } \\
\hline CC1 & Carleton Center for Community Innovation \\
\hline CC 2 & Ottawa Entrepreneurship Center \\
\hline CC3 & CoralCEA \\
\hline
\end{tabular}

\subsubsection{Higher education users inquiring hosted services}

This category includes colleges and Universities that use BigBlueButton in higher capacity and magnitude, some hosting internally, some using external services of companies such as Generic Conferencing.

It is important to keep in mind that these roles are of dynamic natures and are not mutually exclusive. For example while Carleton University plays the role of customer by utilizing 
BigBlueButton system for higher education purposes, it is also a related service provider who offers complementary services, such as faculty members have played a major role as early contributors and support (Steven Megean and Michael Weise), and the University itself as providing academia support and research to BigBlueButton project through TIM program.

\subsubsection{Ecosystem sketch}

Following the identification of the players in the ecosystem, a diagrammatic representation of the network of firms around BBB project, highlighting the nature of their involvement can be sketched.

Iyer et al. (2006) suggest an analysis for creating a sketch of ecosystem which starts with a focal firm's set of key relationships with other players, then iterating the same process for any other player in the network. Given the early stage of ecosystem, where a definite keystone has not emerged, the focal firm in our Subject OS community can be considered BigBlueButton foundation. At this point, the corporate firm who is the main supporter of the OS community (i.e. BlindSide Networks) would be the best candidate for the role of keystone, depending on the consistency in contribution level to the foundation in future.

While the horizontal hierarchy in Figure 6- highlighted the details on firms present in the network, the ecosystem map in Figure 7- will be more abstract, focusing on the roles present in the network and the nature of involvements.

Kilkenny and Nalbarte (2000) categorized the relations among players in a community network into three groups of: money, information, and support. They use arcs to connect the players in 
their ecosystem map which is the common demonstration method, where the relationship between players is represented by the direction of the arc:

- If the arc is away from the player: the player is the transmitter of the value (i.e. money, information, support)

- If the arc is toward the player: the player is the receiver of the value

- If there are at least two arcs one toward and one away: the player is a career of the value The last scenario cannot be generalized since a player can be transmitter of one value and receiver of a different value.

In this research, the nature of relations among players is differentiated by use of different type of arc lines. And the thickness of the lines presents the robustness and intensity of the relations among players.

Iyer and Henderson (2010) uses geometric shapes to represent different types of companies present in cloud vendor ecosystem. 


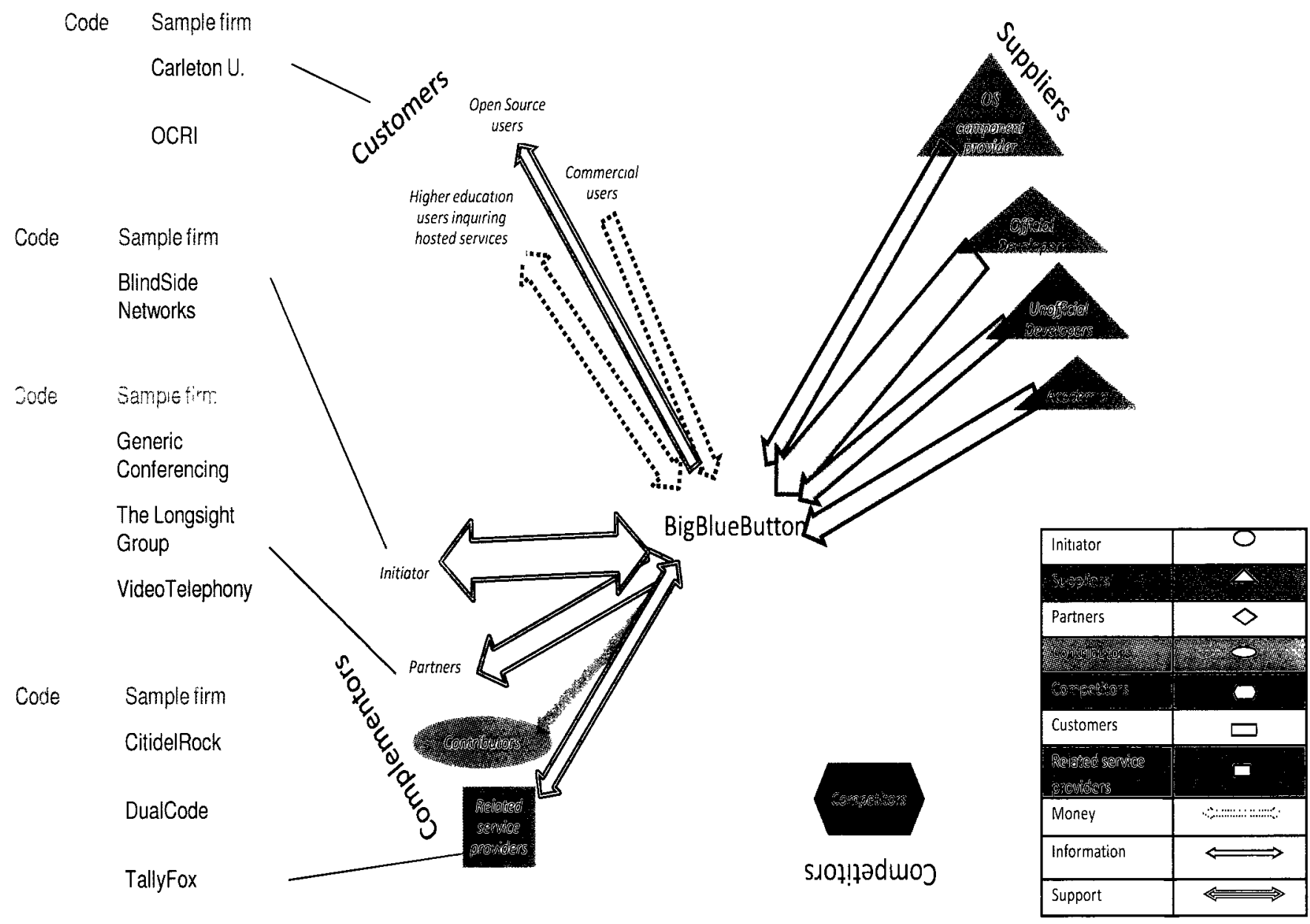

Figure 8: BigBlueButton map 


\subsection{Interviewed firms}

After studying the firms involved in BigBlueButton network, the following nine firms were selected to be interviewed from three categories of customers, partners, and related service providers as illustrated in Figure 7. Firms playing the roles of competitors and suppliers were excluded in sampling, since their presence in the network was not the result of a conscious decision making process.

Table 11: List of interviewed firms

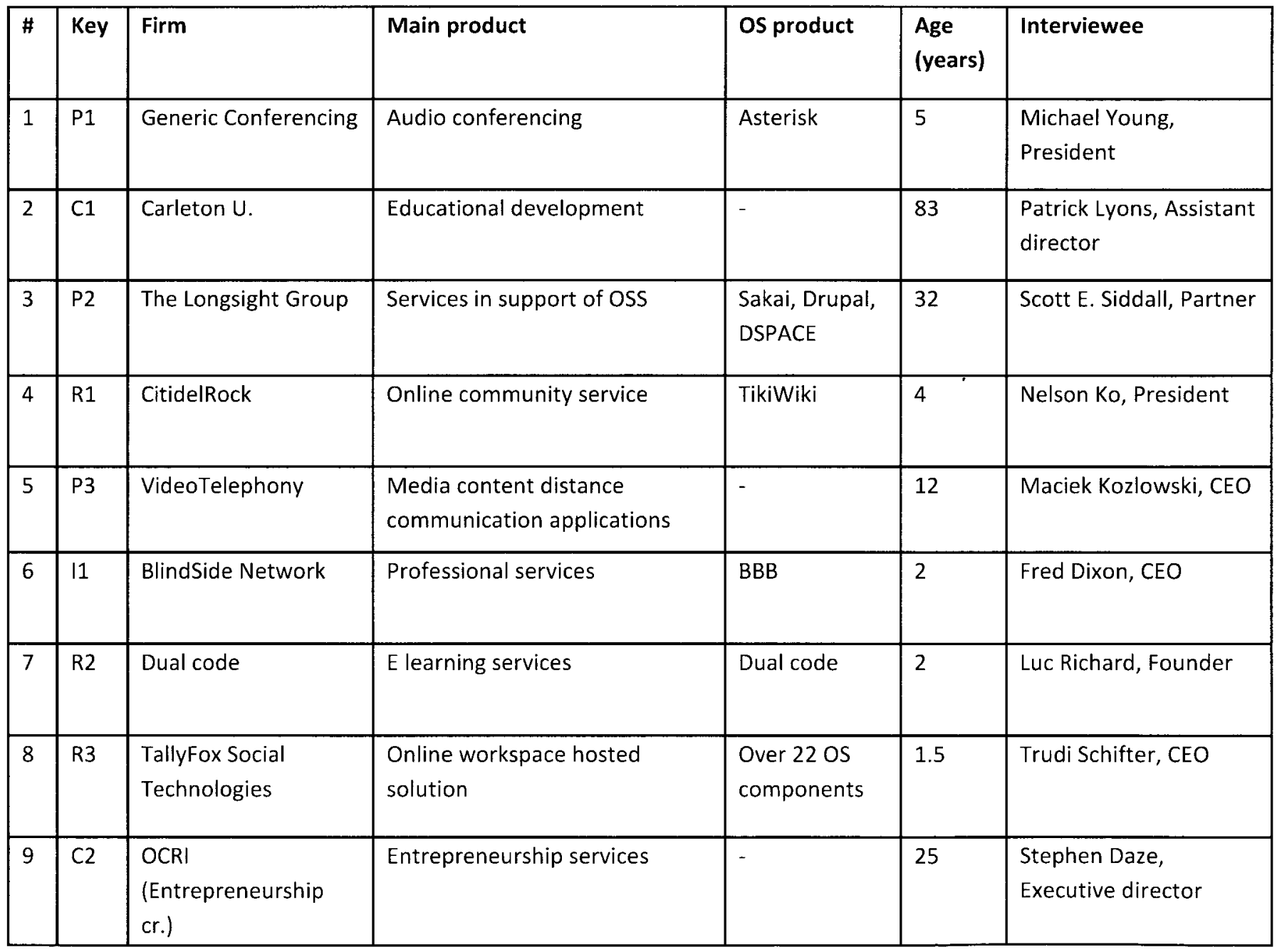




\subsubsection{Interview questions}

A set of interview questions were created by using rational decision making model as a guideline. In order to obtain answers that are unbiased as much as possible, questions were designed so that they did not directly address terms specific to this research, or the key terms in hypothesized frameworks of the research. 


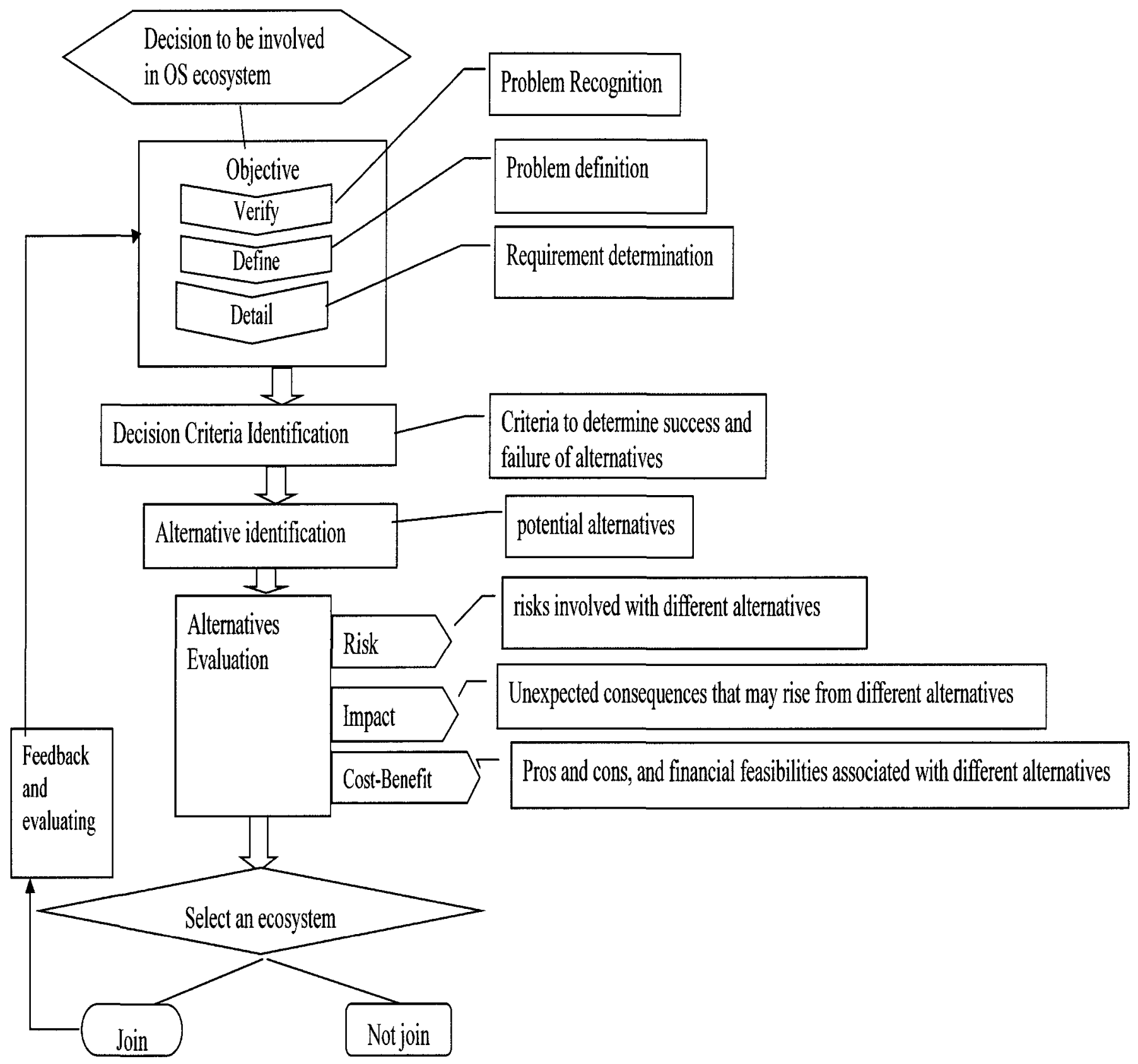

Figure 9: Use of rational decision making model in interview questions 


\subsubsection{Interviewees' introduction and involvement with BBB}

Starting off with a general introduction; interviewees were asked to confirm their position in the firm, insuring that they posses decision making powers and the period of their employment covers the point, at which firm was involved with BBB. Additionally, they were asked to describe their firm's involvement and relation with $\mathrm{BBB}$ as a project, product, or community. Conforming to a semi-constructed interview format; this introduction help set the theme for rest of the interview.

Q1.What is your name and position in the company?

Q2.How many years of experience do you have in your current job?

Q3.What percentage of your job activities is related to BBB?

Q4.What is your involvement or role in BBB?

\subsubsection{Firms' introduction and involvement with BBB}

The second part of the interview questions more specifically and in meticulously inquired about firm's history, experiences and involvements with open source initiatives and BBB in particular.

Q5.What is the founding year of the firm?

Q6. What is the main source of revenue of the firm?

Q7.What percentage of firm's activities and revenue rely on BBB?

Q8.Is your company's main product or services OS or related to BBB? And to what extent? 
Q9.Is your firm contributing to BBB code or just using BBB for complementary products and services? code contribution, free products, hosting forums, mailing lists, engaging with users, bug reports, suggestion and patches of code from developers, involvement in key aspects such as standard setting?

Q10.Is your firm involved with any other OSS projects for the purpose of using OS components in products and services offered by your company?

\subsubsection{Firm's decision to engage in BBB}

This section of interview questions addressed how firms were informed or first heard about $\mathrm{BBB}$, and the business needs, problems that they were expecting to be resolved through involvement in BBB. Also investigated in this section were the alternatives to $\mathrm{BBB}$ and the requirements, risks, and criteria that were considered in choosing BBB over counterparts. The interviewees were asked to tell the history of their experience as a story and series of events that lead them to this point of engagement in $\mathrm{BBB}$, providing the opportunity to reveal unseen details and aspects that may not have been incorporated in questions. Consequently, this segment happened to be substantially informative and instructive in terms of the results that were extracted from interviewees' responses.

Q11.How did your firm become involved with BBB in the first place?

Q12.Were there any specific requirements that needed to be met through getting involved with BBB? 
Q13.Did firm consider any other alternative besides involvement with BBB? If yes what were those alternatives? And how or based on what criteria they were chosen?

a. E.g. good support system, good software, well reputed community

b. E.g. privacy, commitment, time, inconvenience

\subsubsection{Techniques and sources of information used in evaluating BBB}

The last part of the interview questions, addressed the techniques and sources of information that firms used to evaluate different aspects of $\mathrm{BBB}$ against the criteria that were mentioned in last part. Also, they were asked if they actively explored any other firms that were involved with $\mathrm{BBB}$ prior to them, and gained feedback on their experience with BBB. In closing, they were asked to provide any insights or advise to firms interested in involvement with OS initiatives similar to BBB, based on their experience and journey.

Q14.What was some of the information available that helped in evaluating and selecting $\mathrm{BBB}$ ?

Q15.Did you review blogs, news, user support forums, developer's blogs etc. to gain a general idea of activities surrounding BBB?

Q16. How else did you find out about BBB?

Q17.Was any information obtained from other firms that were already involved with BBB about the overall quality of BBB that effected your firm's decision to be involved? (Public information). 
Q18.Did you explore what other firms were involved in BBB? And how did that effect your firm's involvement?

Q19.Has your firm been involved with networks similar to BBB in the past? And did this past experience help in evaluating the quality of BBB and making a decision to be involved?

\subsection{Data Analysis}

The interview responses were analyzed by using cross tabulations to reveal the patterns and differences and draw conclusions accordingly. In some cases, analysis revealed the need for more clarifications on responses; thereafter interviewees were contacted and followed up with to provide more elaborations.

Table 12: Data analysis

\begin{tabular}{|c|c|c|c|c|c|c|c|c|c|}
\hline \multirow[t]{2}{*}{ No. } & \multicolumn{3}{|c|}{ Objectives/ requirements } & \multicolumn{3}{|c|}{$\begin{array}{l}\text { Sources that informed firms } \\
\text { about the existence of OS } \\
\text { ecosystem }\end{array}$} & \multicolumn{3}{|c|}{$\begin{array}{l}\text { Sources that firms rely on in } \\
\text { evaluating OS ecosystem }\end{array}$} \\
\hline & Description & $\begin{array}{l}\# \\
\text { cases }\end{array}$ & $\begin{array}{l}\text { Type } \\
\text { of } \\
\text { actors }\end{array}$ & Description & $\begin{array}{l}\# \\
\text { cases }\end{array}$ & $\begin{array}{l}\text { Type } \\
\text { of } \\
\text { actors }\end{array}$ & Description & $\begin{array}{l}\# \\
\text { cases }\end{array}$ & $\begin{array}{l}\text { Type of } \\
\text { actors }\end{array}$ \\
\hline 1 & $\begin{array}{l}\text { Complement } \\
\text { to current } \\
\text { products } \\
\text { offerings }\end{array}$ & 3 & $\begin{array}{l}2 \mathrm{P} \\
1 \mathrm{R}\end{array}$ & $\begin{array}{l}\text { Active online } \\
\text { search }\end{array}$ & 2 & $\begin{array}{l}1 \mathrm{P} \\
1 \mathrm{R}\end{array}$ & ..... & ..... & $\ldots .$. \\
\hline 2 & $\begin{array}{l}\text { Substitute a } \\
\text { previously } \\
\text { used product }\end{array}$ & 1 & $1 \mathrm{C}$ & $\begin{array}{l}\text { Product } \\
\text { show cases }\end{array}$ & 2 & $\begin{array}{l}1 \mathrm{C} \\
1 \mathrm{R}\end{array}$ & $\ldots .$. & $\ldots .$. & $\ldots .$. \\
\hline 3 & $\begin{array}{l}\text { Substitute } \\
\text { current } \\
\text { product } \\
\text { offerings }\end{array}$ & 1 & $1 \mathrm{P}$ & $\begin{array}{l}\text { Referral from } \\
\text { other OS } \\
\text { communities }\end{array}$ & 1 & $1 \mathrm{P}$ & $\ldots .$. & $\ldots$. & $\ldots$. \\
\hline
\end{tabular}




\begin{tabular}{|c|c|c|c|c|c|c|c|c|c|}
\hline 4 & $\begin{array}{l}\text { Addressing } \\
\text { need in } \\
\text { organization }\end{array}$ & 2 & $\begin{array}{l}1 \mathrm{C} \\
1 \mathrm{R}\end{array}$ & $\begin{array}{l}\text { Referral from } \\
\text { existing } \\
\text { ecosystem } \\
\text { members }\end{array}$ & 4 & $\begin{array}{l}1 \mathrm{R} \\
1 \mathrm{P} \\
1 \mathrm{~K} \\
1 \mathrm{C}\end{array}$ & ...... & $\ldots$. & $\ldots$. \\
\hline 5 & $\begin{array}{l}\text { Integrate to } \\
\text { current } \\
\text { solutions to } \\
\text { enhance } \\
\text { products }\end{array}$ & 2 & $2 \mathrm{R}$ & ......... & $\ldots$ & $\ldots$. & $\ldots$ & $\ldots$ & $\ldots$ \\
\hline
\end{tabular}

\subsection{Analyzing sources that introduced BBB to firm}

By analyzing the interview answers on the subject of sources that informed firms of existence of BBB project, the following findings were obtained.

Four out of nine interviewed firms expressed that they found BBB through referrals from existing ecosystem members. This could be well due to the fact that at early stages of an OS ecosystem selling the vision and direction that key members of OS ecosystem have for the future plays an essential role in convincing other firms to participate. Among other sources that introduced BBB to firms were, active online search performed by a related service provider based in Europe, which makes the geographical distance a factor that hinders more direct and personal forms of introduction. The other two forms of introduction to BBB were expos that show cased the technology and referral from members in other OS communities.

This result indicates the importance of engaging the existing members in recruiting other firms, and focusing marketing activities on the firms with past links or history with ecosystem members. 
Table 13: Firms introduction and contribution to BBB

\begin{tabular}{|c|c|c|c|c|c|}
\hline$\#$ & key & $\begin{array}{l}\text { Involvement } \\
\text { Initiation }\end{array}$ & $\begin{array}{l}\text { Involvem } \\
\text { ent \% }\end{array}$ & Contribution to BBB & $\begin{array}{l}\text { Involvement w/ } \\
\text { other OS }\end{array}$ \\
\hline 1 & P1 & $\begin{array}{l}\text { - Google search } \\
\text { - } 1 \text { year ago }\end{array}$ & $20 \%$ & $\begin{array}{l}\text { - Code contribution } \\
\text { - Bug fixes }\end{array}$ & $\begin{array}{l}\text { asterisk, } \\
\text { alpine, Linux, } \\
\text { MySQL, free } \\
\text { switch, snort }\end{array}$ \\
\hline 2 & $\mathrm{C} 1$ & $\begin{array}{l}- \text { Show case by } \\
\cdot 2.5 \text { years }\end{array}$ & $1 \%$ & $\begin{array}{l}\text { - Funding for requested features } \\
\text { - Feedback on development }\end{array}$ & - No \\
\hline 3 & $\mathrm{P} 2$ & $\begin{array}{l}\text { - Referred by Sakai } \\
\text { comm. } \\
\text { - } 10 \text { months ago }\end{array}$ & $10 \%$ & $\begin{array}{l}\text { - Financing to support dev. } \\
\text { - Bug reports } \\
\text { - Specification of integration with } \\
\text { Sakai } \\
\text { - Strategy opinion sharing } \\
\text { - Promoting }\end{array}$ & $\begin{array}{l}\text { - Sakai } \\
\text { - Drupal } \\
\text { - Dspace }\end{array}$ \\
\hline 4 & $\mathrm{R} 1$ & $\begin{array}{l}- \text { TIM introduction } \\
\text { - Carleton U } \\
\text { - } 2 \text { years }\end{array}$ & $10 \%$ & $\begin{array}{l}\text { - Financial through share of contracts } \\
\text { that include BBB } \\
\text { - Marketing ventures } \\
\text { - Report bugs } \\
\text { - Complementary product and services } \\
\text { (integration w/ tiki) } \\
\text { - Plug in developer (integration code) }\end{array}$ & - Tikiwiki \\
\hline 5 & P3 & $\begin{array}{l}\text { - Contacted by } \\
\text { Carleton U looking } \\
\text { for a product } \\
\text { similar to the one } \\
\text { firm was involved } \\
\text { with } \\
\text { - Developers in } \\
\text { community } \\
\text { - } 3 \text { yrs }\end{array}$ & $20 \%$ & $\begin{array}{l}\text { - Board member } \\
\text { - Source code(future) } \\
\text { - Bug reports (future) }\end{array}$ & $\begin{array}{l}\text { - Epresence (U of } \\
\text { T-year } 19 \text { 99) }\end{array}$ \\
\hline 6 & 11 & $\begin{array}{l}-2 \text { yrs } \\
\text { - Individuals who } \\
\text { started the project }\end{array}$ & $85 \%$ & $\begin{array}{l}\text { - Promoting the OS project that } \\
\text { started in Carleton U } \\
\text { - Co-ordinating releases } \\
\text { - Packaging } \\
\text { - Developing process- design, } \\
\text { customize } \\
\text { - Supporting community } \\
\text { - Providing commercial services to } \\
\text { companies that want to fully } \\
\text { leverage BBB }\end{array}$ & - $N / A$ \\
\hline 7 & R2 & $\begin{array}{l}-2 \text { yrs } \\
\text { - Networking event } \\
\text { with Tony Bailetti } \\
\text { and Fred Dixon }\end{array}$ & $10 \%$ & $\begin{array}{l}\text { - Development (integration with } 3^{\text {rd }} \\
\text { party system-and contributing plug } \\
\text { ins) } \\
\text { - Solution provider }\end{array}$ & $\begin{array}{l}\text { - Coral CEA } \\
\text { - Moodle }\end{array}$ \\
\hline
\end{tabular}




\begin{tabular}{|c|c|c|c|c|c|}
\hline & & $\begin{array}{l}\text { - } 1 \text { yr paid project } \\
\text { from Tony Bailetti } \\
\text { for video } \\
\text { conferencing server }\end{array}$ & & $\begin{array}{l}\text { - Bug reports } \\
\text { - Engaging with users, raising issues } \\
\text { and responding to user enquires }\end{array}$ & \\
\hline 8 & R3 & $\begin{array}{l}\text { - Extensive online } \\
\text { search } \\
\text { - } 1 \mathrm{yr}\end{array}$ & $\begin{array}{c}1 \% \text { (and } \\
\text { rising) }\end{array}$ & $\begin{array}{l}\text { - Feature developments and donating } \\
\text { back to community } \\
\text { - Financial payments for feature } \\
\text { development }\end{array}$ & $\begin{array}{l}\text { - Yes - over } 60 \\
\text { products }\end{array}$ \\
\hline 9 & $\mathrm{C} 2$ & $\begin{array}{l}\text { - Familiarity with } \\
\text { Fred Dixon } \\
\text { (keystone) } \\
\text { - } 1 \text { yr }\end{array}$ & $1 \%$ & - Brand recognition & - No \\
\hline
\end{tabular}

\subsection{BigBlueButton selection process}

By analyzing the interview answers on the subject of BigBlueButton selection process, the following conclusions were achieved, that reflected objectives, alternatives, ecosystem attributes, and ecosystem beyond initiator.

\subsubsection{Decision making objectives}

The results of the interviews indicated that firms' decision to participate in OS ecosystems was a result of five main categories of business objectives that represented variety of business needs and opportunities:

- Complement to current products offerings: the value propositions of the OS ecosystem was considered a good complement to current products offered by the firms in order to create a whole package, and therefore the opportunity was recognized and seized by the firm 
- Substitute a previously used product: the value propositions of the OS ecosystem satisfied business objectives better than the ones that were previously used by the firm, and therefore were selected as a replacement

- Substitute current OS web conferencing product that is being offered to customers as part of a bigger package

- Addressing need in organization: the value propositions of the OS ecosystem addressed a need or a problem that firm has been experiencing

- Integrate to current solutions to enhance products: the value propositions of the OS ecosystem was considered as a value-added to current products offered to firms' customers, and therefore the opportunity was recognized and seized by the firm

\subsubsection{Alternatives}

While partners and related service providers mainly focused on researching alternative OS product for comparison, customers researched both proprietary and OS alternatives. One related service provider went as far as researching what product is currently used by its competitors. Some of the alternative ecosystem choices that were considered by interviewed firms include: DimDim, Illuminate, Wimba, E-presence, and OpenMeeting. 
Table 14: Firms business requirements and alternatives

\begin{tabular}{|c|c|c|c|}
\hline \# & Key & Objectives & Alternatives \\
\hline 1 & P1 & - Complement to current products & - DimDim \\
\hline 2 & C1 & - Substitute a previously used product & - Illuminate \\
\hline 3 & P2 & $\begin{array}{l}\text { Substitute to current proprietary and OS } \\
\text { products used by customers }\end{array}$ & $\begin{array}{l}\text { - Wimba } \\
\text { - Illuminate } \\
\text { - Adobe connect } \\
\end{array}$ \\
\hline 4 & $\mathrm{R} 1$ & $\begin{array}{l}\text { - Value added product to customers } \\
\text { - Used by company itself }\end{array}$ & $\begin{array}{l}\text { - OpenMeetings } \\
\text { - DimDim }\end{array}$ \\
\hline 5 & P3 & - Used for 4 customer projects & - E-presence \\
\hline 6 & 11 & $\begin{array}{l}\text { - Pull business models } \\
\text { - Market share competing with other OS } \\
\text { project } \\
\text { - Firms join: through word of mouth or } \\
\text { website }\end{array}$ & $\begin{array}{l}\text { DimDim (has not updated OS } \\
\text { project in two years, not real OS; } \\
\text { no support, not active) } \\
\text { - OpenMeeting (too complex not } \\
\text { focused on real time collaboration) }\end{array}$ \\
\hline 7 & $\mathrm{R} 2$ & - Integrate to current $\mathrm{E}$ learning solutions & $\begin{array}{l}\text { DimDim (prior to using BBB) } \\
\text { BBB did not come up in the initial } \\
\text { search }\end{array}$ \\
\hline 8 & R3 & $\begin{array}{l}\text { - Integrating in current provide to address } \\
\text { customer need }\end{array}$ & $\begin{array}{l}\text { - Searched top } 20 \text { OS and compared } \\
\text { to proprietary solution } \\
\text { - And what competitors use }\end{array}$ \\
\hline 9 & $\mathrm{C} 2$ & $\begin{array}{l}\text { Addressing the need for a video } \\
\text { conferencing product in centre }\end{array}$ & - Two property products \\
\hline
\end{tabular}

\subsubsection{Ecosystem attributes}

Upon analyzing firms' responses to decision criteria in selecting BBB, it was apparent that these criteria can be categorized into the following three broader groups of different ecosystem attributes that reflect firms' perspective and their business needs:

1. Ecosystem dynamics: This category corresponds to the aspects related to the network of firms, with different roles and levels of involvement and contributions, formed around 
BBB project. Ecosystem dynamics also include factors such as the direction, evolution, management and expansion of this network of firms.

2. OS communities: This category corresponds to the criteria related the OSS development communities, such as the size of the communities, user support, and response on inquires, and speed of feature developments.

3. Technology: This category corresponds to the criteria related to different BBB technology, such as licensing, compatibility, cost, market place, product newness and feature sets.

Analysing the interview responses to the set of questions on this subject showed that firms with more experiences with OS emphasised on criteria related to ecosystem dynamics more than others and contributed more to the OS ecosystem. This finding confirms the fact that the more experience firms have with OS the more they realize that OS is far more than a product, and the significance of the network of firms and players as well as the management behind the progress of this network becomes more clear. Also, it is through these experiences firms get acquainted with the culture of contribution and co-opetion as driving forces behind OS ecosystem, and as a member they play their part in making sure their contribution guarantee the survival of ecosystem and subsequently their own interests.

From the findings in this section it can be concluded that, informing passive participants such as clients of the values related to attributes of OS ecosystem other than the platform can ignite more active participation. 
Table 15: Firms decision criteria and pros $\&$ cons

\begin{tabular}{|c|c|c|c|c|}
\hline \# & Key & Criteria & Pros & Cons \\
\hline 1 & $\mathrm{P} 1$ & $\begin{array}{l}\text { - Openness (licensing), compatibility, } \\
\text { sustainability (license and longevity), } \\
\text { business model (potential of revenue), } \\
\text { vision \&direction }\end{array}$ & $\begin{array}{l}\text { - Potential } \\
\text { - Community and } \\
\text { people }\end{array}$ & $\begin{array}{l}\text { - Young } \\
\text { product }\end{array}$ \\
\hline 2 & $\mathrm{C} 1$ & $\begin{array}{l}\text { - Easy adoption, Accessibility guidelines in } \\
\text { Ontario, specific features (record \& } \\
\text { playback) }\end{array}$ & $\begin{array}{l}\text { - Cost } \\
\text { - User friendly }\end{array}$ & - N/A \\
\hline 3 & P2 & $\begin{array}{l}\text { - Product scalability, Openness (licensing), } \\
\text { cost, support, community }\end{array}$ & $\begin{array}{l}\text { - Potential } \\
\text { - People }\end{array}$ & $\begin{array}{l}\text { - Small } \\
\text { community }\end{array}$ \\
\hline 4 & R1 & $\begin{array}{l}\text { - Platform compatibility } \\
\text { - Fully open source Geographical distance } \\
\text { - License compatibility with companies main } \\
\text { product } \\
\text { - Vision } \\
\text { - Dev interactions }\end{array}$ & - Fully open & $\cdot N / A$ \\
\hline 5 & P3 & $\begin{array}{l}\text { - Independent organization } \\
\text { - Transparent Governance } \\
\text { - Licensing } \\
\text { - Other companies contribution and support } \\
\text { - Position in market place } \\
\text { - Visibility and brand } \\
\text { - Community } \\
\text { - Record and play back } \\
\text { - Interpretation application } \\
\text { - Monetizing the content } \\
\text { - Publishing content from webcast }\end{array}$ & $\begin{array}{l}\text { - Licensing issues } \\
\text { - Community } \\
\text { contribution to } \\
\text { project }\end{array}$ & - Technology \\
\hline 6 & 11 & $\begin{array}{l}\text { - Product } \\
\text { - OS community } \\
\text { - Openness } \\
\text { - Customer: sustainability in future and } \\
\text { support- vibrancy of the community and } \\
\text { support) } \\
\text { - Partner: Market need: regional, language, } \\
\text { skill sets, security system. Differentiating, } \\
\text { value added, merging market: lots of } \\
\text { opportunity) }\end{array}$ & $\begin{array}{l}\text { - Cost savings over } \\
\text { commercial } \\
\text { - Friendly user } \\
\text { interface } \\
\text { - Better support } \\
\text { - Active project } \\
\text { - Speed of } \\
\text { development }\end{array}$ & - N/A \\
\hline 7 & R2 & $\begin{array}{l}\text { - Community Activeness } \\
\text { - Quality of product } \\
\text { - Easy integration to current business } \\
\text { - APIs existence } \\
\text { - Locality } \\
\text { - True open source product }\end{array}$ & $\begin{array}{l}\text { Previous } \\
\text { familiarity and } \\
\text { knowledge of the } \\
\text { technology }\end{array}$ & $\begin{array}{l}\text { - } \text { Commercial } \\
\text { product (good } \\
\text { one)is not OS } \\
\text { - Required } \\
\text { features were } \\
\text { not } \\
\text { implemented } \\
\text { on-time }\end{array}$ \\
\hline
\end{tabular}




\begin{tabular}{|l|l|l|l|l|}
\hline 8 & R3 & $\begin{array}{l}\text { - Functionality (BBB Dial in hosted by generic } \\
\text { conferencing) } \\
\text { - Dial in feature } \\
- \text { Community }\end{array}$ & $\begin{array}{l}\text { - Technical } \\
\text { compatibility }\end{array}$ & $\begin{array}{l}\text { - Small } \\
\text { community } \\
\text { Lack of } \\
\text { transparency }\end{array}$ \\
\hline 9 & C2 & $\begin{array}{l}\text { - Right Product } \\
\text { - Past knowledge of Keystone accountability } \\
\text { - Price } \\
\text { - OS was not a factor }\end{array}$ & $\begin{array}{l}\text { - Technology } \\
- \text { Location } \\
- \text { Cost }\end{array}$ & $\cdot \mathrm{N} / \mathrm{A}$ \\
\hline
\end{tabular}

\subsubsection{Ecosystem attributes and possible motivation levers}

The three categories of ecosystem attributes that were drawn from the criteria that interviewed firms consider in evaluating an early-stage OS ecosystem (i.e. ecosystem dynamics, OS community and platform) also exist in five categories of the motivation levers that Pendergast (2009) identifies:

- Credible OS ecosystem infrastructure to attract potential participants: This category includes documentation and licensing of product, which the results of this research identified as evaluation criteria used by firms to examine technology attribute of an OS ecosystem. Pendergast also emphasises on importance of defining roles of participants and creating membership levels, which the result of this research identified as evaluation criteria used by firms to examine ecosystem dynamics attribute of an OS ecosystem. The last item in this category is support and training, which the result of this research identified as evaluation criteria used by firms to examine OS community attribute.

- Strong offering of resources and opportunities: The results of this research identified opportunities for monetizing business models as evaluation criteria used by firms to examine ecosystem dynamics attribute of an OS ecosystem. 
- A network of inter-organizational relationships: The results of this research identified the existence of sponsoring organizations and their support and contribution to the project as evaluation criteria used by firms to examine ecosystem dynamics attribute of an OS ecosystem.

- Reliable sources of skilled personal and expertise: The results of this research identified the size of OS community as evaluation criteria used by firms to examine OS community attribute of an OS ecosystem.

- Source of funding: The results of this research identified the support of a commercial organization with solid funding resources as an evaluation criteria used by firms to examine ecosystem dynamics attribute of an OS ecosystem.

\subsubsection{Ecosystem beyond initiator}

Analysing the interview responses to the set of questions on this subject showed that firms with least amount of involvement (i.e. customers) disregard the attribute of OS ecosystem that is related to OS community and did not attempt to evaluate or examine any related criteria. They tend to view their involvement as purchasing a product from a seller (ecosystem initiator) and relying on keystone for meeting their current and future expectations. This sort of one dimensional perspective might result in disappointment in a case that keystone leaves its role in ecosystem which would have an immense negative effect on the product if the community is heavily dependent on ecosystem initiator.

From the findings in this section it can be concluded that, while at early stages of ecosystem growth main sponsoring firms plays a major role in setting the future vision and direction, it is 
imperative for future members to examine the keystone efforts in welcoming and even actively acquiring key members that will ensure the survival of ecosystem in absence of main sponsors.

\subsection{Open Source ecosystem evaluation methods}

By analyzing the interview answers on the subject of techniques used by firms to evaluate BBB project, the following findings were obtained.

\subsubsection{Existence of roles}

None of the firms considered existence or lack of certain players (non-keystone) in ecosystem as a factor in making their choice

a. Customers: Not a factor relied heavily on product suitability and keystone reliability

b. Partner and related service providers: Identified competitors for market analysis purposes but did not consider as a threat since: 1- OS nature, 2- very niche oriented. Identified customers to monitor the adoption rate. Identified complementary for development opportunities. 


\subsubsection{Techniques for examining attributes}

Analyzing interview responses on the techniques that firms use to examine different attributes of ecosystem, the following three insights were discovered.

1. Firms do not rely on use the feedback from other (non-keystone) ecosystem members in choosing an early-stage OS ecosystem. In case of customers the fitness of product with their requirement and the keystone pledge on providing future support has been sufficient. In case of partners and related service providers their long term experience in the field and their confidence in the alternative evaluation techniques they used, has been sufficient.

2. Firms rely on techniques that forecast the long run success of an early-stage OS ecosystem. In early stages of growth where the product is still young and not matured enough, firms rely on techniques to help them predict the future of the platform. In case of partners and related service provider with more in depth knowledge and experience with OS ecosystem, these techniques include the examination of business model, funding structure, community independence, transparency, and product scalability. In case of customers the reliance on future vision and direction portrayed by keystone.

3. Firms follow a trend in techniques for to examine attributes of ecosystem with steps that increase in dept and sophistication prompt feedback- use of past experiences to identify current cues- future forecast. 
Table 16: Resources to evaluate criteria

\begin{tabular}{|c|c|c|c|}
\hline \# & Key & Resources to help evaluate criteria & Exploring other firms in ecosystem \\
\hline 1 & P1 & $\begin{array}{l}\text { - People (keystone), } \\
\text { - Community } \\
\text { - Bug reports } \\
\text { - product components (licensing) }\end{array}$ & $\begin{array}{l}\text { - Yes, welcome competitors } \\
\text { - Identified customers }\end{array}$ \\
\hline 2 & $\mathrm{C} 1$ & $\begin{array}{l}\text { - Faculty demonstrations } \\
\text { - Inside relations } \\
\text { - Endorsements } \\
\text { - Forums }\end{array}$ & - No \\
\hline 3 & P2 & $\begin{array}{l}\text { - BBB website (statement) } \\
\text { - Roots in higher education INC. } \\
\text { - Keystone } \\
\text { - Product and components } \\
\text { - Google groups \& discussions }\end{array}$ & - No \\
\hline 4 & R1 & $\begin{array}{l}\text { - Bug reports } \\
\text { - Keystone } \\
\text { - Dev team }\end{array}$ & $\begin{array}{l}\text { - Yes focus on complementors and } \\
\text { whether or not there are more } \\
\text { development opportunities }\end{array}$ \\
\hline 5 & P3 & $\begin{array}{l}\text { - Presentations by Keystone } \\
\text { - Research analysis data (trends, progression } \\
\text { of inquiries, number of downloads) }\end{array}$ & - Yes \\
\hline 6 & 11 & - Google, tweet, references & - Yes (potential competition) \\
\hline 7 & R2 & $\begin{array}{l}\text { - Community: website- activeness of } \\
\text { forums, active users (referring to statistics) } \\
\text { - Google search }\end{array}$ & $\begin{array}{l}\text { - Yes (but not a thread: target } \\
\text { market is niche- and plug-in is a } \\
\text { an OS anyway) }\end{array}$ \\
\hline 8 & R3 & $\begin{array}{l}\text { - Online Search } \\
\text { - Website } \\
\text { - Posted an inquiry and access the } \\
\text { turnaround time to respond } \\
\text { - Google }\end{array}$ & - Yes \\
\hline 9 & $\mathrm{C} 2$ & $\begin{array}{l}\text { - Websites } \\
\text { - Trial } \\
\text { - Google } \\
\text { - Keystone player (Fred Dixon) }\end{array}$ & - No \\
\hline
\end{tabular}


Table 17: Techniques to evaluate criteria

\begin{tabular}{|c|c|c|c|c|}
\hline$\#$ & key & Prompt feedback & Past experiences & Public information \\
\hline 1 & P1 & $\begin{array}{l}\text { - Trial and error joining } \\
\text { the community and } \\
\text { expanding involvement } \\
\text { based on feedback } \\
\text { - Testing product }\end{array}$ & $\begin{array}{l}\text { - DimDim: Management of } \\
\text { project; getting hold of } \\
\text { keystone player- } \\
\text { - asterisk: Unfocused due to } \\
\text { size of the project }\end{array}$ & $\begin{array}{l}\text { - Did not contact firms } \\
\text { in ecosystem to get } \\
\text { opinions }\end{array}$ \\
\hline 2 & $\mathrm{C} 1$ & $\begin{array}{l}\text { - Meeting deadlines } \\
\text { - Fast reply on feature } \\
\text { requests } \\
\text { - Installing and trial of the } \\
\text { product }\end{array}$ & $\begin{array}{l}\text { - Blackboard: communication } \\
\text { line; licensing fee }\end{array}$ & $\begin{array}{l}\text { Did not contact firms } \\
\text { in ecosystem to get } \\
\text { opinions }\end{array}$ \\
\hline 3 & P2 & $\begin{array}{l}\text { - Responsiveness of } \\
\text { keystone } \\
\text { - Commitment to OS and } \\
\text { not driven by marketing } \\
\text { incentives }\end{array}$ & $\begin{array}{l}\text { - Sakai: Positive attributes } \\
\text { aligned with BBB creating }\end{array}$ & $\begin{array}{l}\text { - Did not contact firms } \\
\text { in ecosystem to get } \\
\text { opinions }\end{array}$ \\
\hline 4 & R1 & $\begin{array}{l}\text { - Community (culture of } \\
\text { participation) } \\
\text { - Responses to feedback } \\
\text { - Follow up with bug } \\
\text { reports } \\
\text { - Reassurance of keystone } \\
\text { (statement of purpose) }\end{array}$ & $\begin{array}{l}\text { - Transparency in vision for } \\
\text { future of company } \\
\text { - Enough resources (dev. } \\
\text { Etc.) that secure the future } \\
\text { of project if keystone role } \\
\text { disappears }\end{array}$ & $\begin{array}{l}\text { - Not a main factor, } \\
\text { Carleton involvement } \\
\text { was a facilitator }\end{array}$ \\
\hline 5 & P3 & - Technical compatibility & $\begin{array}{l}\text { - E- presence: RND to OS to } \\
\text { proprietary }\end{array}$ & $\begin{array}{l}\text { - Long experience in } \\
\text { market did not require } \\
\text { feedback from others }\end{array}$ \\
\hline 6 & I1 & $\begin{array}{l}\text { - Forums } \\
\text { - Product trial } \\
\text { - User group } \\
\text { - professional website, } \\
\text { tweet, }\end{array}$ & $\begin{array}{l}\text { - references; } \\
\text { - success stories }\end{array}$ & $\begin{array}{l}\text { - Yes } \\
\text { - Asking other } \\
\text { companies } \\
\text { - Success stories }\end{array}$ \\
\hline 7 & R2 & $\begin{array}{l}\text { - License behind the OS } \\
\text { - Big and active } \\
\text { community } \\
\text { - For new products the } \\
\text { community activeness is } \\
\text { crucial }\end{array}$ & $\begin{array}{l}\text { - Quality of OS product- after } \\
15 \mathrm{yrs} \\
\text { - There is a commercial } \\
\text { company }\end{array}$ & • No \\
\hline 8 & R3 & $\begin{array}{l}\text { - Posting an inquiry and } \\
\text { assessing the turnaround } \\
\text { time }\end{array}$ & $\begin{array}{l}\text { - Dim Dim (lack of support- } \\
\text { not truly open source) } \\
\text { - Sugar CRM (true OS }\end{array}$ & - No \\
\hline
\end{tabular}




\begin{tabular}{|l|l|l|l|l|}
\hline & & & \multicolumn{1}{|c|}{$\begin{array}{l}\text { product- good business } \\
\text { model that sells products })\end{array}$} & \\
\hline 9 & C2 & $\cdot$ Trial of Product & $\cdot$ No & $\cdot$ No \\
\hline
\end{tabular}

\subsection{Results presentation}

The results that were obtained from analyzing the interview data were summarized in the following table, in order to outline the key points and relations. 
Table 18: Result presentation

\begin{tabular}{|c|c|c|c|c|c|c|c|c|}
\hline \multirow[t]{2}{*}{ Role } & \multirow{2}{*}{$\begin{array}{l}\text { Involvement } \\
\text { (initiation } \\
\text { scenarios \& } \\
\text { percentage) }\end{array}$} & \multicolumn{2}{|c|}{ OS ecosystem attributes } & \multicolumn{4}{|c|}{ Techniques for examining attributes } & \multirow{2}{*}{$\begin{array}{l}\text { Available } \\
\text { sources of info } \\
\text { to examine } \\
\text { attributes }\end{array}$} \\
\hline & & & & 1- Probing & $\begin{array}{l}\text { 2- Past OS } \\
\text { experiences }\end{array}$ & $\begin{array}{l}\text { 3- } \\
\text { Consulting } \\
\text { members }\end{array}$ & $\begin{array}{l}\text { 4- } \\
\text { Forecasting }\end{array}$ & \\
\hline \multirow[t]{3}{*}{ Partner } & \multirow[t]{3}{*}{$\begin{array}{l}\text { Active onlıne } \\
\text { search } \\
\text { Referral from } \\
\text { other OS } \\
\text { communities } \\
\text { Referral from } \\
\text { existıng } \\
\text { ecosystem } \\
\text { members } \\
10 \%-20 \%\end{array}$} & $\begin{array}{l}\text { Ecosystem } \\
\text { dynamics }\end{array}$ & $\begin{array}{l}\text { Ability to } \\
\text { monetıze } \\
\text { Abılity to grow } \\
\text { Key individuals } \\
\text { Independent / } \\
\text { transparent } \\
\text { governance }\end{array}$ & $\begin{array}{l}\text { Testıng } \\
\text { keystone } \\
\text { responsıvene } \\
\text { ss }\end{array}$ & Busıness model & N/A & $\begin{array}{l}\text { Commitment } \\
\text { to true OS } \\
\text { Vision \& } \\
\text { direction } \\
\text { Contributions }\end{array}$ & $\begin{array}{l}\text { Keystone } \\
\text { presentation } \\
\text { Website } \\
\text { Research } \\
\text { analysis data } \\
\text { Progression of } \\
\text { inquires } \\
\text { Number of } \\
\text { downloads }\end{array}$ \\
\hline & & $\begin{array}{l}\text { OS } \\
\text { community }\end{array}$ & $\begin{array}{l}\text { Sustaınabılity \& } \\
\text { Support } \\
\text { Size }\end{array}$ & $\begin{array}{l}\text { JoIning the } \\
\text { OS } \\
\text { community }\end{array}$ & $\begin{array}{l}\text { Management } \\
\text { focus }\end{array}$ & $\mathrm{N} / \mathrm{A}$ & N/A & $\begin{array}{l}\text { Bug reports } \\
\text { Groups and } \\
\text { discussions }\end{array}$ \\
\hline & & Platform & $\begin{array}{l}\text { Openness } \\
\text { Compatıbılity \& } \\
\text { Scalabılity } \\
\text { Product age \& } \\
\text { Feature Sets } \\
\text { Cost } \\
\text { Market place } \\
\text { (brand) }\end{array}$ & $\begin{array}{l}\text { Testıng } \\
\text { product } \\
\text { functionality }\end{array}$ & $\begin{array}{l}\text { Examınıng } \\
\text { product for } \\
\text { compatibulıty } \\
\text { and scalabilıty }\end{array}$ & N/A & $\begin{array}{l}\text { Potentials } \\
\text { Product life } \\
\text { cycle }\end{array}$ & $\begin{array}{l}\text { Product } \\
\text { components }\end{array}$ \\
\hline \multirow[t]{3}{*}{$\begin{array}{l}\text { Related } \\
\text { Service } \\
\text { Provider }\end{array}$} & \multirow{3}{*}{$\begin{array}{l}\text { Product show } \\
\text { case Interventions } \\
\text { Actıve onlıne } \\
\text { search } \\
\text { Referral from } \\
\text { existıng } \\
\text { ecosystem } \\
\text { members } \\
10 \%\end{array}$} & $\begin{array}{l}\text { Ecosystem } \\
\text { dynamics }\end{array}$ & $\begin{array}{l}\text { Geographical } \\
\text { distance } \\
\text { Transparency }\end{array}$ & N/A & $\begin{array}{l}\text { Keystone is a } \\
\text { commercial } \\
\text { company }\end{array}$ & $\mathrm{N} / \mathrm{A}$ & $\begin{array}{l}\text { Vision for } \\
\text { future }\end{array}$ & $\begin{array}{l}\text { Keystone } \\
\text { Website }\end{array}$ \\
\hline & & $\begin{array}{l}\text { OS } \\
\text { community }\end{array}$ & $\begin{array}{l}\text { Independent } \\
\text { (survival w/o } \\
\text { keystone) } \\
\text { Activeness }\end{array}$ & $\begin{array}{l}\text { Postıng an } \\
\text { ınquiry }\end{array}$ & $\begin{array}{l}\text { Participation } \\
\text { Size }\end{array}$ & $N / A$ & $\begin{array}{l}\text { Community } \\
\text { interactions }\end{array}$ & $\begin{array}{l}\text { Bug reports } \\
\text { Development } \\
\text { team forums }\end{array}$ \\
\hline & & Platform & $\begin{array}{l}\text { Compatıbılıty } \\
\text { Openness } \\
\text { API's }\end{array}$ & $\begin{array}{l}\text { Testıng } \\
\text { product for } \\
\text { integration }\end{array}$ & $\begin{array}{l}\text { True quality of } \\
\text { OS product }\end{array}$ & N/A & $N / A$ & $\begin{array}{l}\text { Statistics on } \\
\text { active product } \\
\text { users } \\
\text { Google search }\end{array}$ \\
\hline \multirow[t]{3}{*}{ Customer } & \multirow{3}{*}{$\begin{array}{l}\text { Product show } \\
\text { case Interventions } \\
\text { Referral from } \\
\text { existıng } \\
\text { ecosystem } \\
\text { members } \\
1 \%\end{array}$} & $\begin{array}{l}\text { Ecosystem } \\
\text { dynamics }\end{array}$ & $\begin{array}{l}\text { Keystone reliably } \\
\text { Location }\end{array}$ & $\begin{array}{l}\text { Meetıngs } \\
\text { with } \\
\text { keystone }\end{array}$ & $\begin{array}{l}\text { Communication } \\
\text { Deadlines }\end{array}$ & $N / A$ & $N / A$ & $\begin{array}{l}\text { Keystone } \\
\text { Website \& } \\
\text { Forums }\end{array}$ \\
\hline & & $\begin{array}{l}\text { OS } \\
\text { community }\end{array}$ & $N / A$ & $\mathrm{~N} / \mathrm{A}$ & N/A & $N / A$ & N/A & N/A \\
\hline & & Platform & $\begin{array}{l}\text { Adoptability, } \\
\text { compatible w } \\
\text { guidelines } \\
\text { Features } \\
\text { Cost }\end{array}$ & $\begin{array}{l}\text { Installing and } \\
\text { trial of } \\
\text { product }\end{array}$ & N/A & N/A & N/A & $\begin{array}{l}\text { Show case } \\
\text { Google search }\end{array}$ \\
\hline
\end{tabular}




\subsection{Decision process to choose OS ecosystem}

Based on the interview responses, the rational decision making model that was hypnotized in this paper: as argued can be tailored to reflect the decision making process that firms conduct in order to choose an open source initiative, as following:

\section{Step 1: Define objectives of choosing an OS ecosystem}

The findings of this research showed that firms identify following business problem, need or opportunity that motivates firms to consider participation in OS ecosystem:

- Complement to current products offerings

- Substitute a previously used product

- Substitute current OS web conferencing product

- Addressing need in organization

- Integrate to current solutions to enhance products

\section{Step 2: Identify decision criteria to evaluate an OS ecosystem}

The finding of this research confirmed that firms generate evaluating criteria to determine success and failure of their decision to participate in an early-stage OS ecosystem in terms of addressing the objective defined in step one. This research identified three main categories of such criteria which are referred to attributes (i.e. ecosystem dynamics, OS community, and technology) in the context of this research and each include group of objects: 
1. Ecosystem dynamics: This category corresponds to the aspects related to the network of firms, with different roles and levels of involvement and contributions, formed around BBB project. Ecosystem dynamics also include factors such as the direction, evolution, management and expansion of this network of firms.

2. OS communities: This category corresponds to the criteria related the OSS development communities, such as the size of the communities, user support, and response on inquires, and speed of feature developments.

3. Technology: This category corresponds to the criteria related to different BBB technology, such as licensing, compatibility, cost, market place, product newness and feature sets.

Some of the factors noted by firms reflect criteria that are specific to their business requirements such as geographical distance to where the firm is based and compatibility with external technical limitations.

\section{Step 3: Identify alternatives of OS ecosystems}

The findings of this research showed that firms identify number of OS ecosystems as alternatives to their business objectives. Instances of alternative OS ecosystem as identified by firms in this study include: Wimba, DimDim, OpenMeetings, and E-presence.

Having access to information that helps explore all possible alternatives is essential part of this step. The findings of this research showed that firms find or get informed about existence of these ecosystems through number of sources which include:

- Active online search

- Product show cases 
- Referral from other OS communities

- Referral from existing ecosystem members

Step 4: Evaluate different OS ecosystem alternatives

The findings of this research showed that interviewed firms evaluate the attributes of OS ecosystem alternatives found in previous steps and identified pros and cons associated with them. Some of the pros that were identified in evaluating BBB ecosystem were: cost, licensing type (i.e. fully openness of the technology), speed of development, community support, user friendliness of the product, and community contributions to the project. Interviewed firms also identified cons of BBB ecosystem: very young technology, small community, and lack of transparency.

Findings also showed that firms use variety of techniques in evaluating different attributes of OS ecosystems, which are outlined in framework drawn from avian ecology literature and presented in next section.

\section{Step 5: Choose the preferred OS ecosystem alternative}

The research findings showed that interviewed firms chose BBB ecosystem after analyzing the results and comparing alternatives.

\section{Step 6: Re-evaluate the choice}

This step was outside the scope of this research since it takes place over a long period of time and consists of monitoring of the outcomes of the alternative that was chosen in step five. However there are research opportunities around exploring this step in future. 


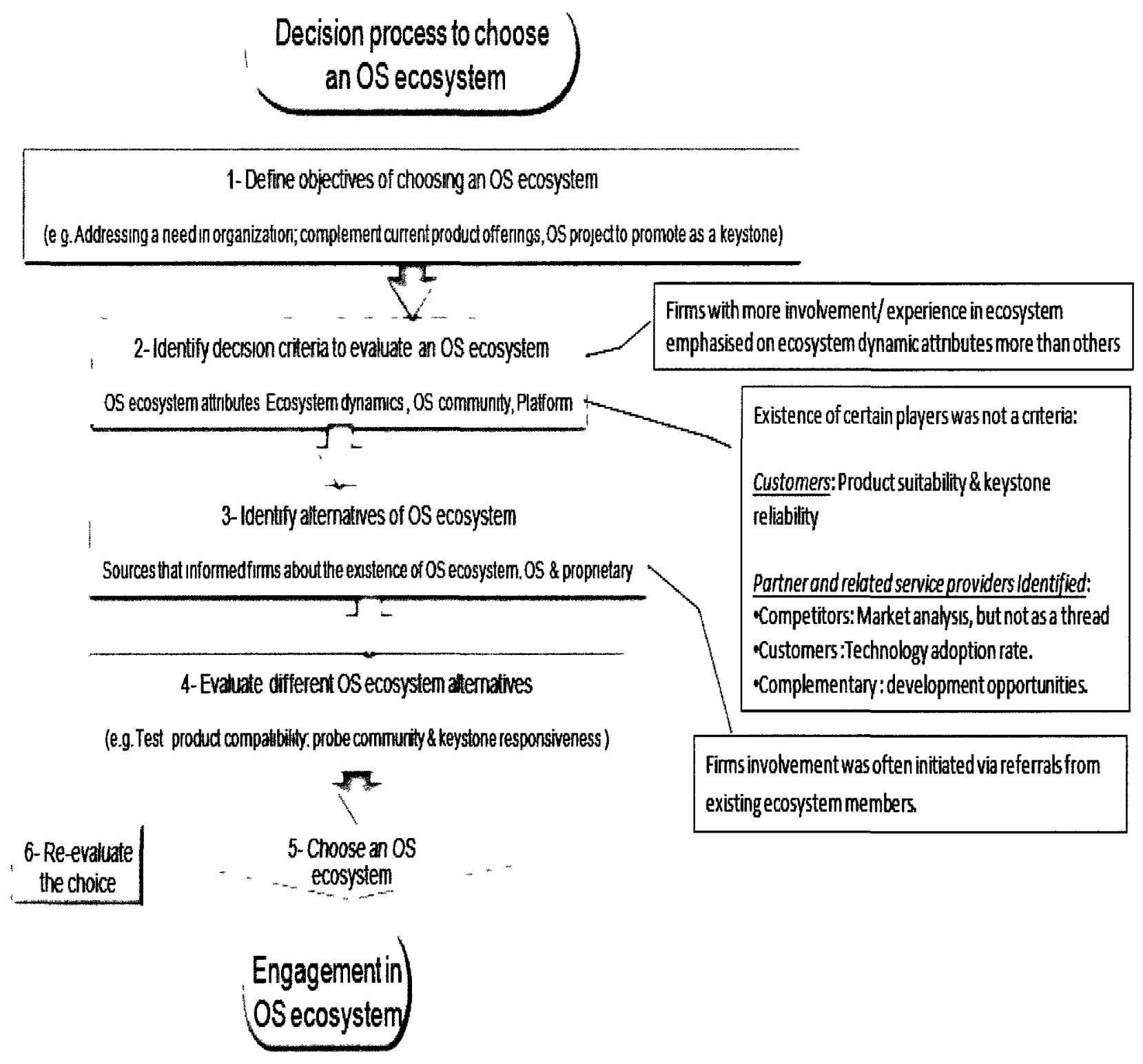

Figure 10: Decision process to choose OS ecosystem 


\subsection{Techniques for evaluating OS ecosystems}

Based on the interview responses, techniques outlined in ecology paper as hypnotized in section 4.1 of this paper, needs to be modified as following to reflect the techniques that firm refer to in order to evaluate attributes of an open source ecosystem.

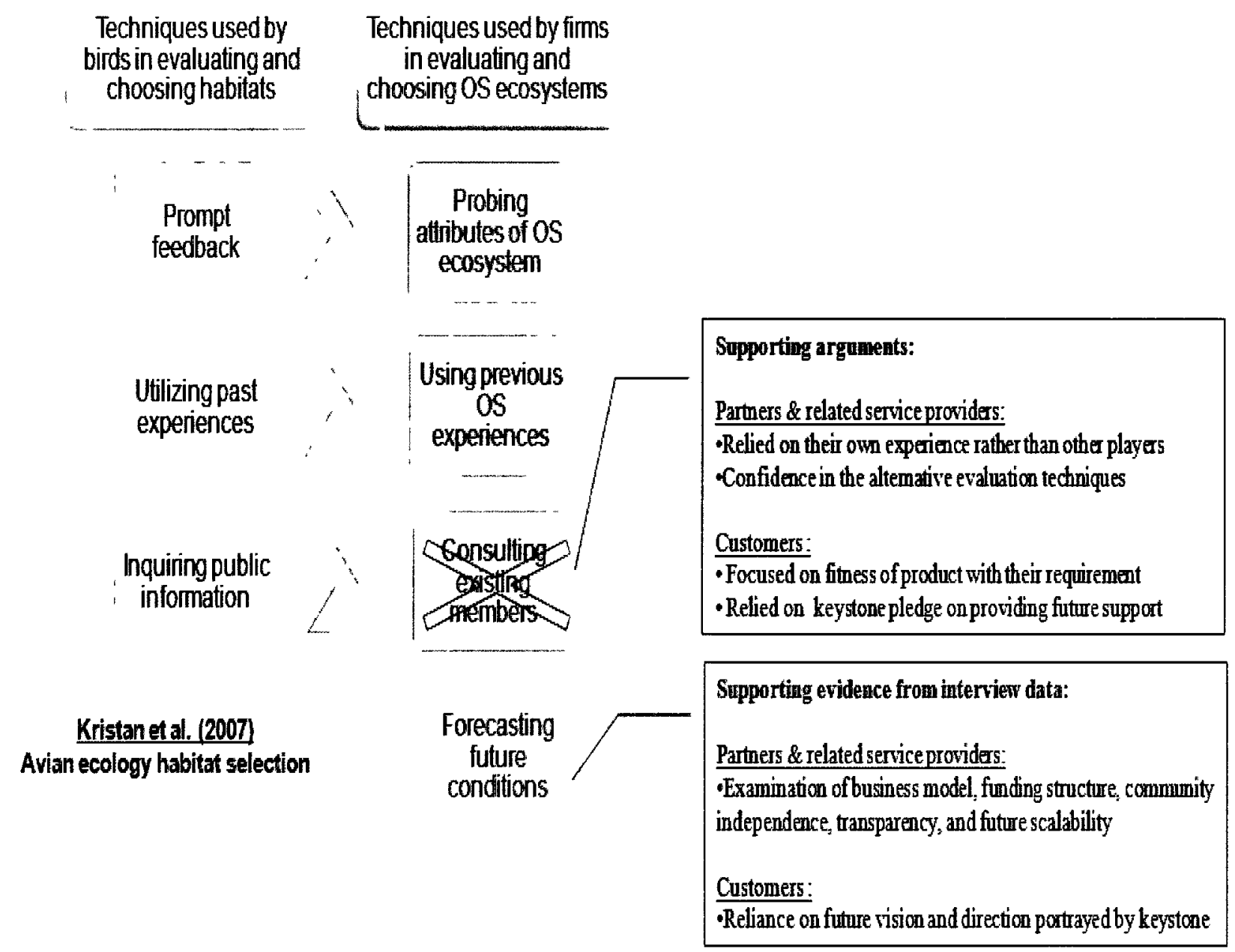

Figure 11: Techniques used in evaluating and choosing OS ecosystems 


\subsubsection{Probing attributes of OS ecosystem:}

Findings from this research show that firms use different probing techniques to test different attributes of an open source ecosystem, for instance:

- Interviewed firms probe ecosystem dynamics by contacting one of the ecosystem sponsoring organizations and test the responsiveness

- Interviewed firms probe OS communities by posting an inquiry in customer support and observing the turn-around time on receiving a reply on their inquiry

- Interviewed firms probe the ecosystem technology by testing product functionality

\subsubsection{Using previous experiences with OS initiatives:}

Findings from this research show that firms use experiences that they have gained through involvement with OS initiatives in past to evaluate different attributes of OS ecosystems, for instance:

- Interviewed firms evaluate ecosystem dynamics by examining its potential for monetizing business models, and support/sponsor of commercial organizations

- Interviewed firms evaluate OS communities attribute of early-stage ecosystems through examining management focus, firms participations and size of the community

- Interviewed firms evaluate technology attribute of ear-stage ecosystems by examining product in terms of compatibility and scalability 


\subsubsection{Consulting existing members:}

Findings from this research show that firms did not consult existing members in the early-stage OS ecosystem due to the following factors:

- Interviewed firms had organization specific objectives and requirement that made other firms' outlook and experience of little or no value to them in making their decision

- Interviewed firms did not find organizations with similar business objectives or requirements in the existing network of firms in order to provide them with opinion or advice, since ecosystem at such early stages has limited number of organizations.

- Interviewed firms preferred to rely on their own judgment, experience, and evaluation techniques and avoid cluttering their decision making process.

\subsubsection{Forecasting future conditions}

Findings from this research show that in addition to the three hypothesized techniques in framework, firms use more sophisticated group of techniques to forecast future conditions of different attributes of an early-stage OS ecosystem:

- Interviewed firms forecast future conditions of ecosystem dynamics by examining its commitment to true OS, and general vision and direction

- Interviewed firms forecast future conditions of OS communities attribute of an earlystage ecosystems through observing community interactions

- Interviewed firms forecast future conditions of technology attribute of an ear-stage ecosystems by analyzing its potential to progress and product life cycle 


\subsection{Sources of information to examine ecosystem attributes}

Findings from this research show that firms use different sources of information to examine three attributes of an early-stage OS ecosystem using the three types of techniques as outlined in the last section:

- Interviewed firms evaluate ecosystem dynamics by referring to the following sources of information: keystone presentation, website, research analysis data, progression of inquires, number of downloads, and forums.

- Interviewed firms evaluate OS communities attribute of an early-stage ecosystems by referring to bug reports, user and developer groups and discussions

- Interviewed firms evaluate technology attribute of an ear-stage ecosystems by visiting product components, statistics on active product users, and Google search

\subsection{Check list for choosing an OS ecosystem}

The results from the data analysis can lead to the following insights for young firms interested in choosing early-stage (young) OS ecosystems:

- Rely on your forecasting abilities and priorities: Ecosystem dynamics, OS community, Technology

- Make a decision on your choice while considering compromises necessary in evaluating an OS ecosystem at early stages 
In addition young firms can follow the steps outlined in the checklist below, in order to evaluate different attributes of an early-stage OS ecosystem. The checklist is organized in nine steps, based on three evaluation techniques: (1) probing, (2) examining and (3) forecasting, used to evaluate each of the three attributes of an OS ecosystem: (1) ecosystem dynamics, (2) OS community and (3) Technology. It is important to note that the order of evaluation techniques represents the level of complexity and depth, starting off with the simplest method of probing, followed by examination methods, and finally the most sophisticated method of evaluation; forecasting. 
Step 1

- Identify and contact the keystone

- Send an inquiry to a key member in keystone

- Assess the turnaround time and level of transparency in response

\section{Step 2}

- Join the community and post an inquiry in the developer group

- Observe the responsiveness of community and the quality of responses and follow ups... - Do not emphasize on size of the community

\section{Step 3}

- Attempt a trial of technology,

- Observe the licensing type,

- The compatibility with your requirement \& the compliance with guidelines

- Overlook minor bugs, but do inquire about them and evaluate the response on plans to fix the bugs
Step 4

- Study the firm playing the role of keystone, website and their statement, their business model....

- Examine the transparency - Identify and study other firms involved in ecosystem

Step 5

- Identify community management focus

- Examine the interactions among community members in developers group

\section{Step 6}

- Examine the licensing of OS components - Look up users feedback about their experience using the technology

- Examine statistics on downloads and active users
Step 7

- Evaluate keystone commitment to true OS \& their efforts in engaging new players

- The future vision and direction of ecosystem

- The level of involvement and contributions of firms in ecosystem

\section{Step 8}

- Forecast the longevity of community based on participation patterns and contributions of key members

- Forecast the of community survivability based on indicators such as dependency to keystone

Step 9

- Forecast technology and platform life cycle - Future potentials (scalability and co ordinance with market trends)

- Forecast the consistency of product based on OS quality indicators 


\subsection{Interview quotes}

At the end of each interview firms were asked to provide any insight or recommendation that can help young firms in their decision making process to choose an early-stage OS ecosystem. some

of which are outlined in the table below.

Table 19: Interview quotes providing insights on choosing OS ecosystems

\begin{tabular}{|c|c|c|c|c|}
\hline \# & key & firm & Interviewee & Quotes and word of advișe \\
\hline 1 & P1 & $\begin{array}{l}\text { Generic } \\
\text { Conferencing }\end{array}$ & $\begin{array}{l}\text { Michael Young, } \\
\text { President, } \\
\text { director }\end{array}$ & $\begin{array}{l}\text { "know the people that are involved more than the technology that are involved, } \\
\text { because people will ultimately decide whether or not the project will be } \\
\text { successful" } \\
\text { "Have a clear business requirement, what do you need to do and how you can } \\
\text { achieve that by using OS" } \\
\text { "The OS model can fail or succeed, the difference is the people involved and } \\
\text { whether or not they are pulling together or pulling apart" }\end{array}$ \\
\hline 2 & $\mathrm{C} 1$ & Carleton U. & $\begin{array}{l}\text { Patrick Lyons, } \\
\text { Assistant } \\
\text { director }\end{array}$ & $\begin{array}{l}\text { "Have the end user try the technology and get them involved in evaluating the } \\
\text { technology- the first step is trying to use the technology" } \\
\text { "The business case needs to make sense" }\end{array}$ \\
\hline 3 & $\mathrm{R} 1$ & $\begin{array}{l}\text { The Longsight } \\
\text { Group }\end{array}$ & $\begin{array}{l}\text { Scott E. Siddall, } \\
\text { Partner }\end{array}$ & $\begin{array}{l}\text { "It needs to be organized, so that there is a clear unbiased leadership" } \\
\text { "There is the presentation, lead by a community that is well organized" } \\
\text { "you don't want one person the keystone specially if they are from the dot com } \\
\text { be the primary manoeuvre and leader in public face, but the perception that it is } \\
\text { lead by many, and there are influential members in user community that impact } \\
\text { the direction of development" } \\
\text { "The open source product is fully OS and is not commercial, even there is one well } \\
\text { capitalized service provider that comes to dominate the community" }\end{array}$ \\
\hline 4 & $\mathrm{R} 2$ & CitidelRock & $\begin{array}{l}\text { Nelson Ko, } \\
\text { President }\end{array}$ & $\begin{array}{l}\text { "Look at the people that are involved rather than the technology that is there." } \\
\text { "Although the code and technology is important, if you are too focused on the } \\
\text { technology is not right" }\end{array}$ \\
\hline 5 & $\mathrm{P} 2$ & Videotelephony & $\begin{array}{l}\text { Maciek } \\
\text { Kozlowski, CEO }\end{array}$ & $\begin{array}{l}\text { "Talk to people that are involved in communities and ask questions about their } \\
\text { experiences. Look at successful communities and why they are. Besides obvious } \\
\text { factors, competitive product in market that OS is an alternative to. Is there a } \\
\text { dominating company that can play the keystone role? What values ecosystem } \\
\text { provide to their business model and how they can contribute in return." } \\
\text { Find out what the community stands for and its brand in market place (e.g. } \\
\text { Redhat take a brand and made it their own - brand identity) }\end{array}$ \\
\hline 6 & 11 & $\begin{array}{l}\text { BlindSide } \\
\text { Network }\end{array}$ & Fred Dixon, CEO & "hence the analogy that people buy from people" \\
\hline 7 & R4 & Dual code & $\begin{array}{l}\text { Luc Richard, } \\
\text { Founder }\end{array}$ & $\begin{array}{l}\text { "people try to sell you a solution there is a tiki factor that needs to take place, and } \\
\text { one of them is trust so if you know the founder" } \\
\text { "for something like BBB which is a young and complex product and doesn't yet do } \\
\text { everything that we need it to do, the community needs to be very active and } \\
\text { preferably funded with somebody with money in their pocket, because if it is all } \\
\text { volunteer work typically it doesn't go very far" }\end{array}$ \\
\hline
\end{tabular}




\begin{tabular}{|l|l|l|l|l|}
\hline 8 & R5 & $\begin{array}{l}\text { TallyFox Social } \\
\text { Technologies }\end{array}$ & $\begin{array}{l}\text { Trudi Schifter, } \\
\text { CEO }\end{array}$ & $\begin{array}{l}\text { "Makes me more comfortable if someone at BBB was following an Open Source } \\
\text { model where they were selling services and had a full profit role to support dev for } \\
\text { a longer term" }\end{array}$ \\
\hline 9 & C2 & OCRI & Stephen Daze & --- \\
\hline
\end{tabular}

The order of emphasis on ecosystem attributes to be evaluated in choosing an OS ecosystem as practiced by firms with more OS experiences are: (1) Direction; (2) People; (3) Technology.

\subsubsection{Direction}

The general direction and evolvement of the ecosystem was expressed by firms with the most experience and involvement in OS initiatives as the most important attribute to be evaluated in choosing an OS ecosystem:

"It needs to be organized, so that there is a clear unbiased leadership. There is the presentation, lead by a community that is well organized. You don't want one person the keystone specially if they are from the dot com be the primary maneuver and leader in public face, but the perception that it is lead by many, and there are influential members in user community that impact the direction of development"

"The open source product is fully OS and is not commercial; even there is one well capitalized service provider that comes to dominate the community"

The Longsight group, Scott E. Siddall, Partner 
"Is there a dominating company that can play the keystone role...? What values ecosystem provide to their business model and how they can contribute in return."

VideoTelephony, Maciek Kozlowski, CEO

\subsubsection{People}

The key people that are involved in the ecosystem was expressed by firms with the most experience and involvement in OS initiatives as the second most important attribute to be evaluated in choosing an OS ecosystem:

"The OS model can fail or succeed, the difference is the people involved and whether or not they are pulling together or pulling apart. Look at people that are involved rather than the technology that is there."

CitidelRock, Nelson Ko, President

"Know the people that are involved more than the technology that are involved, because people will ultimately decide whether or not the project will be successful."

Michael Young, Generic Conferencing, President 


\subsubsection{Technology}

The technology that the ecosystem is anchored around was expressed by firms with the most experience and involvement in OS initiatives as the third most important attribute to be evaluated in choosing an OS ecosystem:

"Have the end user try the technology and get them involved in evaluating the technology- the first step is trying to use the technology"

Carleton U. Patrick Lyons, Assistant director

"Besides obvious factors, consider competitive product in market that $O S$ is an alternative to."

VideoTelephony, Maciek Kozlowski, CEO 


\section{Conclusions}

This chapter outlines conclusions obtained throughout the course of this research as well as opportunities for future research.

\subsection{Research Conclusions}

The conclusions of this research aim to provide insights to young firms pursuing opportunities in early-stage OS ecosystems, through highlighting the practices conducted by firms with more experience in the field of OS in order to evaluate different attributes of an early-stage OS ecosystem.

One of the key conclusions that can be drawn from this research is the value of prior experience and knowledge with OS initiative as a defining factor in efficiency and elaboration and comprehensiveness of the decision making process that firms follow in order to evaluate and join OS initiatives. This experience was manifested in the emphasis that the firms with more OS involvement experience placed on least perceptible attributes of OS ecosystem such as ecosystem dynamics, as well as use of most sophisticated methods of evaluation; forecasting.

This finding can be of great value to young firms that might be discouraged by apparent shortcomings such as the newness of the technology or small sized communities in early-stage OS ecosystem, and miss the indications of future viability that are hidden in ecosystem dynamics attributes.

It is also worth noting that since firms with more OS experiences are more aware of culture of OS, and the role that the members play in its success; they provided the highest level of 
contributions to the ecosystem. This can be also a great lesson for young firms to consider the potential contributions that they can make to an early-stage OS ecosystem as a factor in choosing one that can add value to their long-run business returns.

The surprising finding that firms did not reach out for feedback from existing ecosystem members was evidence that firms rely on techniques that evaluate the fitness of ecosystem with their specific business requirement rather than the general health of ecosystem as seen and experienced with other firms with different business requirements. The lesson that this finding provides to young firms is careful identification and elaboration of their true business objectives and goals that need to be addressed through participation in an early-stage OS ecosystem. In other words firms need to take a customized approach in evaluating OS ecosystem alternatives and while using techniques that best reflect their needs, avoid inclusive reliance on following pigeon-hole practices.

Keystones/initiators play a defining role in acquiring the key members in early stages of OS ecosystem growth. The findings of this research show that a strong focus should be directed toward responsiveness and promptness in addressing inquiring by keystones/initiators. The marketing and recruiting activities should be targeted on firms with past acquaintances with keystone or OS project, who can compromise the shortcomings of the young platform with the reliability of people and direction of the ecosystem.

To summaries, in choosing an early-stage OS ecosystem firms need to look beyond the traditional factors that measured current health of an ecosystem and focused first on the fitness of the ecosystem with their requirement and then identifying elements that help them forecast its future. 


\subsection{Opportunities for Future Research}

Being a preliminary research, this thesis opens a wide range of future research opportunities. There is an opportunity of researches anchored around multiple case studies which will overcome some of the challenges this research was facing in terms of the limited number of candidates for interview sampling. Also, a future research that studies the subject OS ecosystem in more matured stages of growth, and compares the findings against the ones of this research can provide invaluable insights on efficiency of methods used by firms in evaluating OS initiatives. The later research can lead to frameworks and research on optimization of techniques that were used and outlined in this research, specifically the forecasting technique. 


\section{References}

- Adner, R. (2006), Match your innovation strategy to your innovation ecosystem, Harvard Business Review, April,98-107.

- Ågerfalk, J.,: Supporting Global Software Development in Open Source Ecosystems: A Role for Actability in the Pragmatic Web. PragWeb 2006: 153-165

- Ahlering, M.A. and J. Faaborg. 2006. Avian habitat management meets conspecific attraction: if you build it, will they come? The Auk 123: 301-312.

- Alkhatib, J., (2006), Free Open Source as a Technology Transfer tool in the Arab World, Fachhochschule Brandenburg, Technology and Innovation Management, http://flosshub.org/system/files/Khatib_FOS.pdf

- Bailetti, T. 2009. Business Ecosystems: A New Form of Organization Creative Individual Worldwide, Speaker Series. MaRS Collaboration Centre. Toronto

- Basole, R. (2009), Visualization of interfirm relations in a converging ecosystem, Journal of Information Technology, 24, 144-159.

- Bloom, P., \& Dees, J. G. (2008), Cultivate your ecosystem, Stanford Social Innovation Review, Winter, 47-53.

- Borgatti, S. (2006), Identifying a set of keyplayers in a social network, Computational and Mathematical Organizational Theory, 21, 21-34.

- Brandenburger, A., \& Nalebuff, B. (1995), the right game: use game theory to shape strategy, Harvard Business Review, July-August, 57-71.

- Groeber, Patrick, Schweitzer, Frank and Press, Kerstin (2009). 'How Groups Can Foster Consensus: The Case of Local Cultures'. Journal of Artificial Societies and Social Simulation $12(2) 4$ <http://jasss.soc.surrey.ac.uk/12/2/4.html>.

- Chesbrough, H., \& Garman (2009), How open innovation can help you cope in lean times, Harvard Business Review, December, 68-76.

- Clark, R.G. \& Shutler, D. 1999: Avian habitat selection: pattern from process in nest-site use by ducks? -Ecology 80: 272-287

- Dahlander, L. \& Magnusson, M. 2008. How do firms make use of open source communities?, Long Range Planning, 41(6, December): 629-649.

- Dekker, A.H. and Colbert B. Network Robustness and Graph Topology. Proceedings of ACSC04, the 27th Australasian Computer Science Conference, 18-22 January 2004, Dunedin, New Zealand.

- Dhanaraj, C. \& Parkhe, A. (2006), Orchestrating innovation networks, Academy of Management Review, 31(3), 659-669. 
- Dortch, M. 2007. The Open Source Ecosystem Matures: Observations and Recommendations. Robert Frances Group (MFG). Customer Research Note [Online]. ftp://ftp.software.ibm.com/linux/pdfs/IBMandtheOpenSourceEcosystemRFG0807.pdf . Accessed: 13 February 2011.

- Feller, J., Finnegan, P. and Hayes, J. (2008) Delivering the 'Whole Product': Business Model Impacts and Agility Challenges in a Network of Open Source Firms, Journal of Database Management. In Press.

- Fletcher, A. 2008. Open Source Unleashed [Online]. http://alexfletcher.typepad.com/all bets off/eclipse/ Accessed: 13 February 2011.

- Franklin, J.F., Lindenmayer, D., MacMahon, J.M., McKee, A., Magnuson, J., Perry, D.A., Waide, R., Foster, D., 2000. Threads of continuity. Conserv. Biol. Pract. 1, 9-16

- Franklin, J.F., MacMahon, J.A., 2000. Messages from a mountain. Science 288, 1183-1185

- Garshelis, D.L. 2000. Delusions in habitat evaluation: measuring use, selection, and importance. Pages 111-164 in L. Boitani and T.K. Fuller [EDS.], Research techniques in animal ecology: controversies and consequences, Columbia University Press, New York, NY U.S.A

- Hagel, J., Brown, J. S., \& Davison, L. (2008), Shaping strategy in a world of constant disruption, Harvard Business Review, October, 81-89.

- Hauge, Ø., \& Ziemer, S. (2009), Providing Commercial Open Source Software : Lessons Learned In: Proceedings of the 5th IFIP Working Group 2.13 International Conference on Open Source Systems (OSS2009) - Open Source Ecosystems : Diverse Communities, June 3rd-6th, Skövde, Sweden Edited by:Cornelia Boldyreff, Kevin Crowston, Björn Lundell, Anthony I Wasserman. 7082 Springer

- Hardings, J., 2007. Identifying challenges for a productive and sustainable Open Source ecosystem [ http://gsyc.es/ herraiz/fosdem2007/papers/workshop-proposal.pdf ] Pontificia Universidad Cat'olica de Chile, February 10, 2007

- Harper, T.L., \& Stein, S.M. (1995), Out of the post-modern abyss: Preserving the rationale for liberal planning. Journal of Planning Education and Research 14:4, 233-244.

- Hartigh, E., M. Tol, et al. (2006). The Health Measurement of a Business Ecosystem. ECCON 2006 Annual meeting: Organisations as Chaordic Panarchies. The Netherlands.

- Hudson, D., \& Stoyan, T., (2011), Using collectives to enable sustainable growth in technology startups. Sprott School of Business, Carleton University; Working Paper.

- Iansiti, M., \& Levien, R. (2002): Keystones and Dominators - Framing the operational dynamics of business ecosystem; Working Paper.

- Iansiti, M., \& Levien, R. (2004a); Strategy as ecology; Harvard Business Review; March, pp.68-78.

- lansiti, M., \& Levien, R. (2004b); The keystone advantage: what the new dynamics of business ecosystems mean for strategy, innovation, and sustainability; Harvard Business School Press, Cambridge (MA). 
- lansiti, M., \& Richards (2006), The information technology ecosystem: structure, health, and performance, Antitrust Bulletin, 51(1), 77-110.

- Iyer, B., Lee, C.-H., \& Venkatraman, N. (2006), Managing in a "small world ecosystem": lessons from the software sector, California Management Review, 48(3), 28-47.

- Iyer, B. \& Henderson, J. C. (2010). Preparing for the Future: Understanding the Seven Capabilities of Cloud Computing. MIS Quarterly Executive, Vol. 9, No. 2, pp. 117-131

- Johnson, M. D., 2007. Measuring Habitat Quality: A Review. The Cooper Ornithological Society. The Condor 109: 489-504.

- Kilkenny, M., \& Nalbarte, L. (2000), Keystone sector identification, TVA Rural Studies, Contractor Paper 00-08,May, http://www.uky.edu/Ag/AgEcon/pubs/tva/staff/Kilkenny0008.pdf.

- Kristan, W. B. 2007. Special Section: Choices and Consequences of Avian Habitat Selection. The Condor 109: 485-488.

- Leibold, M. A., Economo, E. P. and Peres-Neto, P. (2010), Metacommunity phylogenetics: separating the roles of environmental filters and historical biogeography. Ecology Letters, 13: 1290-1299. doi: 10.1111/j.1461-0248.2010.01523.x

- MacAulay, M. 2010. Open Source Business Resource: Interdisciplinary Lessons [Online]. http://www.osbr.ca/ojs/index.php/osbr/article/viewArticle/1169/1120. Accessed: 13 February 2011.

- Milinkovich, M. 2009. Eclipse Foundation. Interview with T. Pendergast, 17 march, 2009.

- Moore, J. (2006), Business ecosystems and the view from the firm, Antitrust Bulletin, 51(1), 3175.

- Pearce, T. \& Bailetti, T. 2007. Open Source Software - Beyond the Download Button. Proceedings of the 2007 Fall Simulation Interoperability Workshop.

- Pendergast, T. (2009), Identifying potential open source ecosystem participants based upon organizational motivation and ability, Carleton University (Canada), 2009, 182 pages; AAT MR52045

- Rasmussen, $E$, Moen, $\varnothing \&$ Gulbrandsen, M 2006, 'Initiatives to promote commercialization of university knowledge', Technovation, vol. 26, pp. 518-533.

- Rasmussen, E \& Borch OJ 2010, 'University capabilities in facilitating entrepreneurship: A longitudinal study of spin-off ventures at mid-range universities', Research Policy, vol. 39, pp. 602-612.

- Robbins, S. P., \& Judge, T. A. (2007)..Organizational Behavior, 12e Chapter 5: Perception and Individual Decision Making (12th ed.). Upper Saddle River, New Jersey: Pearson Prentice Hall. ISBN: 9780132431569

- Sergio, F. and Newton, I. (2003), Occupancy as a measure of territory quality. Journal of Animal Ecology, 72: 857-865 
- Stuermer, M., Spaeth, S. and Von Krogh, G. (2009), Extending private-collective innovation: a case study. R\&D Management, 39: 170-191. doi: 10.1111/j.1467-9310.2009.00548.x

- Sydow, J. (1998), Understanding the Constitution of Interorganizational Trust. In: Lane, C./Bachmann, R. (Eds.): Trust within and between Organizations. Oxford University Press. Oxford, 31-63

- Sydow, J. and A. Windeler (1998): Organizing and evaluating interfirm networks: a structureationist perspective on network processes and effectiveness, Organizational Science, vol27, no.4, pp47-75.

- Thomas, D., \& Hunt, A., "Open Source Ecosystems," IEEE Software, vol. 21, no. 4, pp. 89-91, July/Aug. 2004, doi:10.1109/MS.2004.24

- Yoffie, D. B., \& Kwak, M. 2006. "With Friends Like These: The Art of Managing Complementors." Harvard Business Review 84, no. 9

- Weiss, M. \& Moroiu, G. (2008), Ecology and Dynamics of Open Source Communities. In S. K. Sowe\& I. Stanelos \& I. Samoladas (Eds.), Emerging Free and Open Source Software Practices: 4867: |GI Global.

- Weiss, M., \& Gangadharan, G.R. (2010), Modeling the Mashup Ecosystem: Structure and Growth, R\&D Management, 40(1), 40-49.

- Weaver, C., J Jessop, V Das. (1985), Rationality in the public interest: notes toward a new synthesis, in Rationality in Planning: ciritical essays on the role of rationality in urban and regional planning. Ed. Breheny, M. and A Hooper. Pion, London.

- Wright, M, Clarysse, B, Mustar, P \& Lockett, A 2007, Academic entrepreneurship in Europe, Edward, Elgar Publishing, Cheltenham.

- Wynn Jr., D. (2007). Assessing the Health of an Open Source Ecosystem. In Sowe, S. K., Stamelos, I. G., \& Samoladas, I. (Eds.), Emerging Free and Open Source Software Practices. (pp. 238-258). 